\title{
Contribuição ao Estudo da Planície Litorânea do Estado do Paraná $^{\wp}$
}

\author{
João José Bigarella \\ Instituto de Biologia e Pesquisas Tecnológicas
}

\begin{abstract}
The present paper contains an approach to systematize the study of the State of Parana coastal plains, in the southern part of Brazil. It contains in general some geographical and geological data, documented by maps, sketches and photographs. In the initial stage the coastal plain represents a marine ingression, caused by faulting. This ingression penetrated the valleys of a not yet determinated geological landscape. Ended the movement of deeping by faulting begins the epirogenic ascension and building of the barriers and beach ridges. An intensive sedimentation caused the lagoons and bays obstruction. This work refers mainly to t33

he sedimentary formations and the coastal plains is classified in the following way for the study in consideration to the morphology and origin: Marine sedimentation - shore, barrier and beach ridge; Intermediary sedimentation mangrove swamps, mud and sand banks and mangrovito; Continental sedimentation - dunes and terrestrial alluvion. There are also presented some data about the rocky coast and vegetation.
\end{abstract}

Key Words: Costal plains; State of Paraná; Marine sedimentation; mangrove swamps; mangrovito; Continental sedimentation; Eolic dunes

\section{GENERALIDADES}

O litoral paranaense apresenta, no seu estágio inicial, uma ingressão marinha que penetrou profundamente nos vales de uma paisagem de época geológica ainda não bem determinada. BACKHEUSER (1918, p. 3-4) refere-se a movimentos de submersão "ocorrido provavelmente até o decorrer do terciário", submersão esta que deu origem à Serra do Mar, com o seu aspecto característico.

$\mathrm{Na}$ opinião de Maack $^{1}$, durante o terciário, talvez ainda no cretáceo, em conseqüência do tectonismo dos Andes, produziu-se um desequilibro continental que ocasionou grandes linhas de falha, originando na parte oriental do continente a elevação de blocos limitados regionalmente e afundamento de uma faixa continental. Em consequiência desse afundamento, efetuou-se nos vales de uma paisagem cretácica-terciária uma ingressão marinha, que formou a maioria das baias brasileiras; no Estado do Paraná as baias de Paranaguá e Guaratuba. Uma vez terminado o afundamento e os movimentos tectônicos, iniciouse novamente durante o quaternário, a ascensão epirogênica dessa faixa, que continua nos nossos dias (MAACK, 1946, p. 246).

Após o afundamento de parte do bloco continental, originando a Serra do Mar, o litoral apresentava-se como uma costa rica em enseadas, pontais e ilhas.

\footnotetext{
$\wp$ Artigo publicado no Arquivos de Biologia e Tecnologia, v. 1, pp. 75-111, 1946.

${ }^{1}$ Carta ao Dr. Loureiro Fernandes, julho de 1942. Arquivada no Museu Paranaense.
} 
Essa costa, durante o quaternário, situar-se-ia aproximadamente na linha de contato do complexo cristalino com a planície litorânea quaternária (fig. 1).

Após terminado o afundamento, iniciou-se a retificação da linha da costa através de uma sedimentação intensa. Formaram-se cordões litorâneos, que cresceram em direção ao mar, sobre a plataforma continental, na forma de restingas (beach ridge). A formação dos cordões litorâneos implicou no aparecimento de lagoas, lagunas e baias. As primeiras desapareceram em conseqüência de intensivo entulhamento. Atualmente, o litoral do Estado do Paraná não apresenta lagoas ou lagunas típicas.

O litoral paranaense desenvolve-se entre a vila de Ararapira e a barra do rio Saí-Guaçú. Vila de Ararapira: Lat. $=25^{\circ} 12^{\prime} 44^{\prime \prime} ; \mathrm{L}=48^{\circ} 01^{\prime} 15^{\prime \prime} \mathrm{W}$. Grw. Barra do rio Saí-Guaçú: Lat. $=25^{\circ} 58^{\prime} 38^{\prime \prime}$; L $=48^{\circ} 35^{\prime} 26^{\prime \prime} \mathrm{W}$. Grw. ${ }^{2}$

A planície litorânea é uma planície com cerca de 10 a $20 \mathrm{~km}$ de largura, e atinge o máximo de 50 km na baia de Paranaguá. É constituída de formações arenosas, paludais terrestres, manguezais (paludais marinhos) e nas proximidades do complexo cristalino por terrenos de aluviões terrestres. A altitude em sua maior extensão varia de zero a $10 \mathrm{~m}$ sobre o nível do mar. Nos pontos mais interiores atinge $20 \mathrm{~m}$ de altitude. É bordada a este pelo oceano e ao oeste pelo limite montanhoso do complexo cristalino, constituído pela Serra do Mar e suas ramificações (fig. 1).

$\mathrm{Na}$ planície, observam-se ilhas de complexo cristalino (shantungs) que representam antigos pontos de apoio para a sedimentação e bordados atualmente por larga planície.

A retificação da linha de costa levou a formação das baias de Paranaguá e Guaratuba, baias típicas de ingressão marinha, que dividem a planície litorânea em três partes, compreendidas: a este, pelas praias do Superaguí, de Leste e do Sul (praia Grande do Saí). A baia de Paranaguá estende-se por cerca de $46 \mathrm{~km}$ terra a dentro, com largura máxima de $10 \mathrm{~km}$. Compreende diversos setores com denominações próprias: Antonina, Laranjeiras e Pinheiros. Nela se situam os portos principais do Estado: Paranaguá e Antonina. A baia de Guaratuba estende-se por $15 \mathrm{~km}$ terra a dentro e possui a largura máxima de $5 \mathrm{~km}$. Ambas as baias

\footnotetext{
${ }^{2}$ Extraído do Mapa do Município de Paranaguá, organizado pelo Departamento de Terras e Colonização do Estado do Paraná.
}

apresentam numerosas ilhas e extensos manguezais. $\mathrm{O}$ entulhamento dessas baias processa-se de maneira intensa tendendo para colmatação completa das mesmas.

Os rios que cortam o litoral têm as nascentes na parte montanhosa do complexo cristalino, ou nas baixadas pantanosas. $\mathrm{O}$ curso superior, encachoeirado, situa-se sobre o complexo cristalino, e sua direção está subordinada à estrutura geológica. As suas águas são límpidas, em contraste com as do curso inferior.

Os riachos menores correm, por entre blocos e matacões, e abaixo dos detritos que enchem os vales $^{3}$.

Os rios ao atingirem a planície tornam-se meandrantes, com aspecto de senilidade. Através das regiões pantanosas, sua água é escura, em consequiência da presença de matéria orgânica e

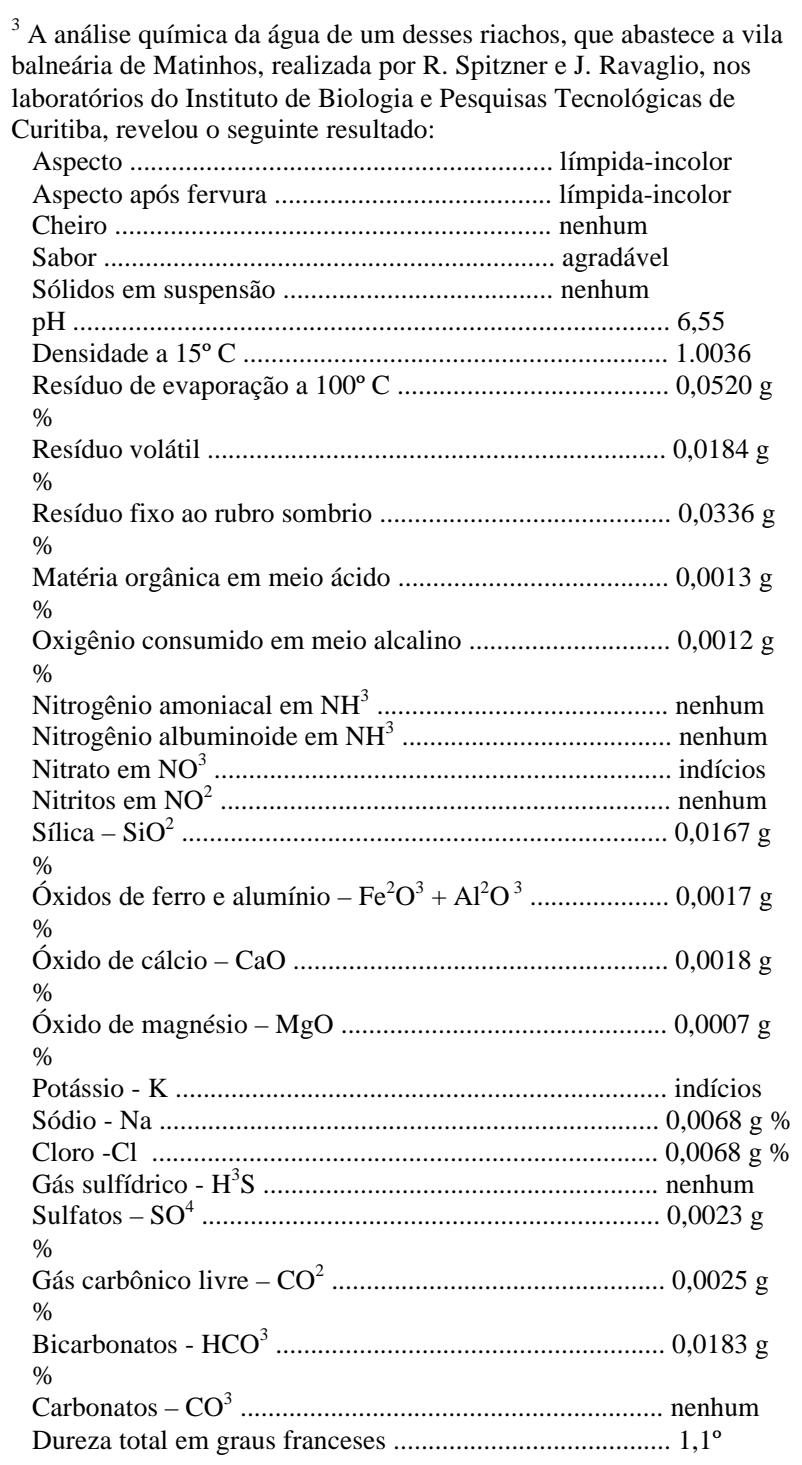


tem sua velocidade muito reduzida. Os rios na planície sofrem comumente a influência das marés muitas vezes até algumas dezenas de quilômetros acima da foz.

A planície litorânea é constituída de sedimentos de origem marinha, intermediária e terrígena, depositados diretamente sobre o embasamento cristalino; morfologicamente a classificamos da seguinte maneira:

$\begin{array}{cc}\text { Sedimentação marinha } & \text { Praias } \\ \text { Restingas } & \\ \text { Sedimentação intermediária - Manguezais } & \text { Bancos de lodo e } \\ & \text { areia (recentes e } \\ & \text { antigos) } \\ & \text { Mangrovitos } \\ \text { Sedimentação terrígena } & \text { - Aluviões terrestres } \\ & \text { Dunas eólicas. }\end{array}$

Antes de iniciarmos o estudo das formações sedimentares, apresentaremos algumas observações sobre os pontos rochosos do litoral paranaense.

\section{PONTOS ROCHOSOS DO LITORAL PARANAENSE}

A ação constante das vagas sobre as costas rochosas tem um efeito mecânico considerável, efeito esse que muito bem podemos observar no litoral paranaense, onde, além de causar a destruição das rochas, abrindo falésias, cliffs e grutas de vagas nos paredões rochosos, produz o aplainamento das superfícies rochosas com a formação de terraços ou planos de abrasão. Os cliffs são abertos por uma gradual erosão e apresentam um nível de base onde se inicia o ataque e onde se produz o aplainamento (LAHEE, 1941).

Se a região sofre um levantamento ou ocorre um abaixamento do nível no mar, a superfície em aplainamento (terraço) é abandonada abrindo-se novo cliff mais abaixo com a formação de novo terraço e assim sucessivamente. Os terraços representariam períodos de estacionamento do movimento relativo do continente e oceano. Estas formas escalonadas, que se observam no litoral do Brasil Meridional são conseqüentes dos movimentos epirogênicos, considerados por certos autores como movimentos isostáticos e por outros como movimentos eustáticos. Não sendo da alçada desta contribuição, não trataremos de tal assunto, reservando-nos somente a apresentação dos fatos. Os afloramentos rochosos diretamente na costa paranaense são poucos, constituindo ilhas de complexo cristalino, bordados de um lado pela planície sedimentar e do outro pelo mar. A Serra da Prata mergulha no oceano entre Caiobá e Guaratuba (fig. 2 e 27). No oceano se observam ilhas rochosas que são os picos mais elevados de uma região submergida. Entre elas destacamos as ilhas dos Currais e Itacolumi. A face marinha dos afloramentos rochosos apresenta falésias e cliffs, assim como terraços marinhos, demarcando certos níveis de abrasão. Notamos em certos pontos a presença de grutas de vagas e marcas de marés (fig. 28).

Nos diversos pontos do litoral por nós examinados encontramos alguns níveis de erosão característicos; assim verificamos a presença de terraços em altitudes compreendidas entre $3 \mathrm{~m}, 7$ m e $10 \mathrm{~m}$ e muito característico entre $25 \mathrm{~m}$ e $32 \mathrm{~m}$ (fig. 29 e 30).

Em excursão realizada a Itanhaen no litoral paulista com o prof. Dr. K. E. Caster e os assistentes do Departamento de Geologia da Faculdade de Filosofia, Ciências e Letras da Universidade de São Paulo, Drs. J. C. Mendes e R. O. de Freitas, verificamos a presença de terraços no litoral situados a $7 \mathrm{~m}$ e a cerca de $30 \mathrm{~m}$ sobre o nível do mar.

Os afloramentos do complexo cristalino, constituídos de gnaises, gnais-granitos e granitos, são cortados por diques de diabásio de direção NW-SE (N $320^{\circ}$ E magn.), (fig. 31). Característica é na zona litorânea, a presença de morros com a forma de pão de açúcar. Segundo FREYBERG (1930), os cones rochosos limitados por faces planas, quase que verticais (pães de açúcar), são originados pela decomposição e se aprofunda rapidamente. Tal fenômeno se produz, principalmente, em região de clima tropical, onde a decomposição das massas graníticas não pode acompanhar a dos pegmatitos e fendas. O material decomposto é removido rapidamente, isolando massas, que posteriormente são arredondadas por decomposição lenta e sucessiva e tomam forma tronco-cônica. As faces expostas diretamente à insolação sofrem descamação.

Verificamos na Serra da Prata e em morros isolados a presença de blocos e matacões, desagregados principalmente pela ação contínua do mar, que deixaram mais para o interior vestígios de antigas falésias (fig. 3). A variação da 
temperatura teve a sua influência sobre os matacões semi-mergulhados, produzindo-lhes dilatações e contrações irregulares, originando rompimento de núcleos (Kernsprünge), (fig. 32), conforme se verificou em diferentes alturas, sobre o nível do mar.

A erosão diferencial, decompondo mais rapidamente os diques de diabásios, produz vales reentrantes na topografia do complexo cristalino. As lavagens e os respingos salgados contribuem na erosão diferencial das rochas, para a formação de sulcos, buracos e outras escavações de diferentes tamanhos e característica para cada tipo de rocha (fig. 33).

Nas costas rochosas verificamos a presença de pequenas cavidades arredondadas de diâmetros vários e situadas abaixo e acima do nível do mar (fig. 34). Na literatura geológica essas cavidades são consideradas como produzidas por escavações de ouriço do mar. RIOJA LO BIANCO, citado por CABRERA (19--, p. 401 e seg.), descreve os ouriços como animais que se alimentam de algas, que atapetam as rochas. Afirma que algumas espécies, como o ouriço comum, são sedentárias, e voltam, sem engano, ao lugar onde vivem, após deslocamentos em busca de alimentos. O hábito de viver sempre no mesmo lugar se acentua nos animais que povoam costas rochosas. Nelas, por mais duras que sejam, escavam cavidades, nas quais se alojam e de onde é difícil desalojá-los. O mar, por mais açoito que seja, não lhes produz o menor dano, sendo indispensável mesmo à vida destes animais. $\mathrm{O}$ testemunho de muitos observadores parece atribuir a ação de escavar principalmente a um atritar contínuo dos espinhos e dentes sobre a rocha desde a juventude do ouriço, conseguindo, primeiramente, uma cavidade na qual se aloja e que mais tarde vai aumentado conforme requeira o crescimento. Os ouriços, assim protegidos não se encontram isolados, mas em agrupamentos numerosos, às vezes de centenas de animais.

Este autor considera tais escavações como produzidas por ouriços do mar, argumentando a sua afirmação. Assim, as diferentes altitudes das cavidades já abandonadas sobre o nível do mar indicariam uma maior altura primitiva das águas do mar. Em contrário, OLIVEIRA e LEONARDOS (1943, p.766) afirmam poderem os ouriços do mar viver nos rochedos fora da água até alguns metros acima do nível do mar.

A bibliografia compulsada sobre a biologia destes equinodermes não trás informações satisfatórias sobre a possibilidade de eles viverem fora da água durante certo tempo. No entanto tudo leva a admitir que, sendo o ouriço do mar animal de respiração essencialmente branquial (MORTENSEN e LIEBERKIND, 1928, p. 96) com um sistema de vasos aquosos auxiliares da respiração (WINTERSTEIN, 1921, p. 56), a permanência fora da água além dos limites das marés seja impossível. Convém lembrar ainda a esse propósito, que as experiências fundamentais de VON UEXKÜLL (1897, p. 466) não só a cavidade geral do corpo como o sistema de vesículas de que o animal é provido intervém na mecânica respiratória. O funcionamento destes órgãos se não exige um fluxo contínuo de água que se dá na preamar, todavia não despreza a presença do líquido que se deposita nos nichos durante o período da baixa-mar. Assim pois, pelo que se conhece atualmente sobre a respiração destes equinodermes, não se pode afirmar serem capazes de resistir normalmente fora da água por intervalos maiores do que o das marés. Devemos acentuar que em casos excepcionais, ouriços pescados, muitas vezes perdem o líquido da cavidade do corpo, que é preenchida pelo ar atmosférico. Nestas condições os animais flutuam na água e podem resistir durante alguns dias. PERRIER $(1875$, p. 633-634, 637) que fez estas observações, admite a existência de respiração intestinal. Aqui, porém, o veículo principal de oxigênio é a água e não o ar.

Em palestra o prof. Dr. K. E. Caster levantou dúvidas sobre a possibilidade dos ouriços conseguirem construir semelhantes nichos nas rochas. Percorremos, em sua companhia, trechos dos costões de Itanhaen e da ilha de São Sebastião, no litoral do Estado de São Paulo, verificando uma diferença entre a erosão diferencial comum dos gnaises e os chamados buracos de ouriço. $\mathrm{Na}$ enseada do Sombrio, na ilha de São Sebastião, nas rochas alcalinas verificamos grande número dessas formas abaixo e a muitos metros acima do nível do mar, cuja origem para nós é ainda incerta. Segundo informações do prof. Dr. Paulo Sawaya, os ouriços do mar encontrados nas costas rochosas vivem geralmente nesses nichos abaixo do nível do mar. Nichos desse tipo, quando encontrados acima do nível do mar não constituem ainda uma prova do movimento relativo do continente $\mathrm{e}$ oceano. 


\section{SEDIMENTAÇÃO MARINHA}

\section{PRAIAS}

No litoral do Estado do Paraná, as praias se estendem por cerca de $90 \mathrm{~km}$. São interrompidas por pontos de costa rochosa, formados por afloramentos do complexo cristalino e também pelas baias de Paranaguá e Guaratuba. Ao norte, situa-se a praia de Superaguí com cerca de $36 \mathrm{~km}$ de extensão, no centro a praia de Leste com cerca de $30 \mathrm{~km}$ e ao sul a praia do Sul com $12 \mathrm{~km} \mathrm{e}$ outras praias como a praia de Guaratuba, Mel, etc., apresentam extensão menor e aqui não são consideradas.

A largura da praia, tomada em relação à baixamar, varia em regra de 50 a $80 \mathrm{~m}$, podendo, em certos lugares, como no Pontal do Sul, atingir 200 m. a sua inclinação é geralmente suave e variável. Quando, porém, se acentua, acusa pouco além do limite da baixa-mar, uma concavidade paralela à costa. No bordo oriental dessa concavidade (conhecida regionalmente por lagamar) tem origem a primeira arrebentação; quando a arrebentação transpõe esse bordo ela desaparece transformando-se numa onda normal; nova arrebentação produz-se nas proximidades da praia. $\mathrm{O}$ bordo oriental dessa concavidade representaria a fase inicial de um novo avanço da terra sobre a plataforma continental na forma de beach ridge feixe de restinga (fig. 4). A largura dessa concavidade é muito variável, geralmente superior a $50 \mathrm{~m}$.

A costa brasileira é bordejada pela corrente equatorial brasileira, apresentando, junto ao litoral, contra correntes e correntes secundárias, vindas do sul, produzidas pelos ventos dominantes do quadrante sul e sudeste. Em consequiência dessas correntes, as barras dos rios são dirigidas para o norte, e migram constantemente nessa direção, até um ponto, em que são entulhadas pelas areias. Formam-se, entre a praia e a restinga, lagoas estreitas e compridas. Essa situação não perdura: o rio abre nova barra num ponto de menor resistência, reiniciando nova migração para o norte. Em diversos pontos, próximos aos rios, encontram-se, na zona da praia, vestígios desse fenômeno. Ocasionalmente, surgem ao longo das praias, correntes secundárias vindas do norte. São pouco frequientes e sem grande importância. A linha da costa, como se nos apresenta, tem, como principal responsável pela sua formação as correntes secundárias vindas do sul. Os taboleiros arenosos do Cambará, Pereira, Guarani e Taboleiro, antigas praias, pela sua situação e morfologia, atestam que sua formação é devida às correntes marinhas vindas do norte (fig. 1 e 7).

A ação das correntes marinhas e das ondas é responsável pela construção e modificação das linhas de praia. As correntes transportam o material mecanicamente e as ondas selecionam-no. Realizamos diversas análises mecânicas dessa formação (fig. 6), verificando a porcentagem máxima dos grãos de areia, situada entre os diâmetros $0,125 \mathrm{~mm}$ e $0,5 \mathrm{~mm}$. Um depósito praial sempre é estratificado (fig. 35). As linhas claras observadas na figura 35 são constituídas quase que exclusivamente por grãos de quartzo e as linhas escuras principalmente por ilmenita.

Durante as análises mecânicas dos sedimentos observamos maior porcentagem de ilmenita à medida que os furos dos tamises diminuem, abaixo de $0,062 \mathrm{~mm}$ a porcentagem de ilmenita é dominante.

A linha de praia tende a atingir o seu perfil de equilíbrio. Conseqüentemente, transformações mais ou menos importantes são realizadas. Pontos há, onde o mar penetrou terra a dentro algumas centenas de metros. É bem de ver, porém, que não se trata de afundamento, mas de modificações nas correntes marinhas que bordeiam o litoral. MARTYN (1934, p. 293) refere-se à mudança freqüente da linha da costa na Guiana Inglesa como consequiência da variação das correntes. $\mathrm{Na}$ Ilha do Mel, o cliff atual da linha de praia está aberto em mangrovitos (bancos antigos de manguezal solevados ao nível do mar, vulgarmente conhecidos por piçarra), essa ocorrência só seria explicada admitindo-se uma linha de praia situada no mínimo a algumas centenas de metros mais à frente (fig. 5 e 36). Antigos moradores da praia de Leste afirmam que o mar avançou cerca de $150 \mathrm{~m}$ na região do Pontal do Sul. No Rio Guarituba, na praia de Matinhos, o mar operou ligeiro avanço, abrindo cliff em mangrovitos ou depósitos paludais aterrados com areias eólicas. Ocorrências semelhantes tivemos ocasião de observar $\mathrm{n}$ ilha de Santo Amaro, no litoral paulista.

Os ripple-marks, alongados e alinhados paralelamente à praia, onde se encontram freqüentemente, são considerados por FREYBERG (1930) como ripples de movimentos de marés. Na praia verifica-se uma pavimentação (Pflasterstellung), com valvas e restos de 
moluscos, cerca de $90 \%$ das valvas acham-se com a concavidade voltada para baixo (fig. 37). Esse fato segundo FREYBERG (1930) indica um lugar onde predomina a sedimentação. Os lugares onde se encontra irregularidade na disposição das valvas indicaria um lugar onde predomina o transporte, e as areias acham-se em movimento.

A praia é despida de vegetação até o limite máximo das marés. Segue-se a zona das antedunas e a zona das pequenas dunas eólicas (RAWITSCHER, 1944, p. 21), nesta região pouco desenvolvida, devido a falta de ventos fortes (fig. 8). O vento predominante é o SSE e SE. A umidade do clima, contribui para a menor mobilidade das areias da praia em direção à terra, principalmente à noite quando sopram ventos contrários que fazem voltar atrás partes das areias transportadas durante o dia (RAWITSCHER, 1944, p. 21). Estabelece-se assim, um movimento de areias, terra a dentro, que vai originar as pequenas dunas eólicas, sobre as restingas. Caracterizamos as ante-dunas pela associação dos vegetais de fixação das areias: Ipomoea pes caprae, Remirea marítima, etc. (fig. 38, 39 e 40).

\section{RESTINGAS}

O termo restinga é usado no Brasil significando um membro da formação litorânea. As restingas são formações arenosas constituídas por cordões litorâneos (barrier em inglês, Nehrung em alemão) e pelos feixes de restingas propriamente ditos (beach ridge em inglês). $\mathrm{O}$ feixe de restingas representa um agrupamento paralelo de cordões litorâneos. $\mathrm{O}$ estudo da formação e evolução das restingas na costa brasileira foi de uma maneira clara e precisa tratado por LAMEGO (1940).

$\mathrm{O}$ ambiente no qual tem origem a formação da restinga são as enseadas e ângulos mortos ocasionados por ilhas ou pontais rochosos, sendo de importância uma fonte constante de sedimentos e sua distribuição pelas correntes marinhas. Segundo LAMEGO (1940, p. 16), a origem da restinga é de um modo geral condicionada à existência de correntes costeiras secundárias transportando areias. A abundância do material arenoso arrastado pela corrente e o seu perene abastecimento são causas decisivas na sua formação. $O$ seu processo de formação consiste numa corrente tangenciando a massa de água que a separa da praia, perdendo velocidade no contato e depositando os sedimentos numa faixa paralela à linha costeira. É também função da profundidade das marés costeiras.

Os sedimentos transportados pelas correntes são depositados nos já mencionados ângulos mortos provocados pelas ilhas ou pontais rochosos de onde avançam na forma de esporões (spit em inglês), constituindo línguas de areias; são orientados pelas correntes. Terminada a construção do esporão temos um cordão litorâneo (restinga), que se nos apresenta como uma faixa longa e estreita, medindo muitas vezes, várias dezenas de quilômetros. Como exemplo clássico de restinga temos no Brasil a restinga de Marambaia, no Estado do Rio. No litoral paranaense, principalmente nas barras das baias temos a forma de esporões. Formam bancos de sedimentos arenosos, ainda submersos, orientados pelas correntes, e constituem núcleos de outras futuras restingas. $\mathrm{Na}$ enseada de Caiobá, entre o morro das Caieiras e a ponta de Caiobá, estende-se um banco de sedimentos submersos, o "Banco Grande", orientado na tangência das correntes secundárias, vindas do sul, com as correntes de marés da barra da baia de Guaratuba. Sobre este banco produz-se a arrebentação das vagas oceânicas (fig. 41). O cordão litorâneo isola geralmente do mar lagoas ou lagunas que posteriormente são entulhadas e transformadas em regiões pantanosas (fig. 9). Temos aí sempre um limite nítido entre a restinga e tais regiões pantanosas. O litoral paranaense apresentou, no seu estado inicial de formação, este tipo de restinga, porém, atualmente não temos um tipo simples de cordão litorâneo, visto não termos lagoas isoladas do mar por restinga.

A forma que se encontra, comumente, é de beach ridge, que designamos por feixe de restingas, isto é, uma sucessão de cordões litorâneos intercalados com partes baixas brejosas, cobertas de vegetação típica; segundo LAMEGO (1940) - vales de restingas (fig. 10).

$\mathrm{O}$ aspecto das restingas é modificado secundariamente pela ação dos ventos, com a formação de dunas eólicas. O desenvolvimento dos feixes de restingas no litoral paranaense é relativamente pequeno, e constituído em regra de 2 ou 3 indivíduos. A distância entre as restingas é variável e indica o valor do avanço terrestre sobre a plataforma continental. Lugares há, como na vila Balneária, em que apreciável é a distância entre as restingas, aí notamos a presença de riachos, alagadiços e brejos nos vales de restingas. Ao norte de Matinhos entre duas restingas próximas 
observa-se um riacho com mangue, e mais acima, além do limite da ação da maré, há uma vegetação de brejo típica, com perí-perí (Ciperus princeps).

Análise mecânica dos sedimentos de um antigo cordão litorâneo, em Sertãozinho a cerca de $2 \mathrm{~km}$ ao oeste da vila balneária de Matinhos, revelou tratarem-se os mesmos, de sedimentos menos selecionados do que os sedimentos de praia e do interior das baias. Sedimentos de restingas mais recentes revelaram um grau de seleção maior que o antigo cordão litorâneo de Sertãozinho (fig. 25).

A restinga apresenta-se com a forma de faixas longas, estreitas e abauladas, de altitude variável de $3 \mathrm{~m}$ a $7 \mathrm{~m}$. Na região da praia de Leste as restingas do interior são designadas vulgarmente por taboleiros. As formações arenosas junto ao mar são designadas também por campinas e cômoros. São cobertas de vegetação halopsamófila nas regiões mais próximas ao mar onde as areias conservam ainda uma certa salinidade. Mais para o interior é constituída por matas. Os vales de restingas mais antigos, ainda pantanosos, são cobertos com matas de aspecto diferente da mata pluvial tropical da região serrana. Nas matas da planície litorânea ocorrem, de uma maneira notável, as palmáceas, observadas principalmente na estrada do Mar.

Estudamos mais detalhadamente a região Matinhos-Caiobá, onde realizamos levantamentos para a construção de uma pequena planta topográfica-geológica (fig. 7) e de um perfil geológico (fig. 3) ${ }^{4}$. Nessa região, a planície sedimentar quaternária (holocênica), estende-se desde o limite do complexo cristalino até a orla do mar, com a largura máxima de $2 \mathrm{~km} \mathrm{e} \mathrm{o}$ comprimento de $3,5 \mathrm{~km}$ (fig. 42). Morfologicamente, apresenta as formações arenosas de restinga. A mais antiga mede de $5 \mathrm{~m}$ a $7 \mathrm{~m}$ de altitude: Taboleiro e Sertãozinho (fig. 43) e a mais recente formando os tômbolos de Caiobá e Matinhos e a faixa arenosa entre essas localidades com $2 \mathrm{~m}$ a $3 \mathrm{~m}$ de altitude sobre o nível do mar. Entre essas formações, situa-se uma zona relativamente plana, em sua maior parte, pantanosa, com altitude de $1 \mathrm{~m}$ a $2 \mathrm{~m}$ sobre o nível do mar (fig. 2). Nesta zona surgem esporadicamente pequenas ilhas arenosas. A planície sedimentar, na orla do mar, apresenta vegetação halo-psamófila de fixação das areias,

\footnotetext{
4 Palestra realizada pelo autor na associação dos Geógrafos Brasileiros - Núcleo de Curitiba, em outubro de 1945, sob o título: Algumas notas sobre a Geologia da Região Matinhos-Caiobá.
}

constituída principalmente por gramíneas e ciperáceas. Na restinga próxima ao mar ocorre uma flora psamófila parcialmente halófila passando a xeromorfa mais para o interior. A zona pantanosa é coberta de mata em sua maior parte. No Herbário do Museu Paranaense, encontra-se o seguinte material coletado nas praias e ante-dunas do litoral paranaense, sendo que as poucas espécies determinadas são as que seguem:

Salicornia gaudichaudiana MAQ.

Remirea maritima AUBL.

Sporobolus virginicus KUNTH.

Panicum racemosum SPRENG.

Hydrocotyle umbellate L.

Ipomoea pes caprae SWEET.

Acicarpha spathulata R. BR.

Cenchrus echinatus L.

RAWITSCHER (1944, p. 21-22), cita, além dessas espécies as seguintes para o litoral paulista, as quais muito provavelmente devem também ocorrer nesta zona, porém ainda não foram determinadas na coleção do Museu Paranaense:

\author{
Sesuvium portulacastrum $\mathrm{L}$. \\ Statice brasiliensis BOISS. \\ Spergularia marina GRIESB. \\ Conocarpus erecta $\mathrm{L}$. \\ Iresine portulacoides MOQ. \\ Telanthera maritima MOQ. \\ Ipomoea acetosaefolia ROEM. et SCHULT. \\ Canavalia obtusifolia DC. \\ Polygala cyparissias ST. HIL. \\ Scaevola plumierii VAHL.
}

As camadas superficiais dos sedimentos arenosos das restingas possuem uma coloração clarocinzenta que vai progressivamente passando a amarela até castanho nas camadas inferiores. A coloração claro-cinzenta da superfície é proveniente da lavagem por águas pluviais e pelo descoramento por ácido húmico. À maior profundidade foi verificada um aumento na porcentagem de ferro sob a forma de óxido de ferro hidratado e de matéria orgânica. A coloração amarelo até castanho é conseqüente à matéria orgânica, óxido de ferro hidratado e às argilas provenientes do transporte marinho ou da decomposição dos feldspatos sedimentados, juntamente com os grãos de quartzo e outros minerais.

A altitude das restingas decresce do interior para a praia o que indica, segundo JOHNSON (1938, p. 439), 
um movimento positivo da região. As formações arenosas, antigos cordões litorâneos, situadas no interior da planície, são conhecidas regionalmente por taboleiros: Cambará, Guarani, Taboleiro, etc. Nesta denominação também são incluídos os antigos bancos de lodo e areia, da sedimentação intermediária solevados sobre o nível do mar, e os mangrovitos. Junto ao mar, como já vimos, a restinga é denominada regionalmente por campina. Os tômbolos ocorrem também na região. Entre eles salientamos o de Matinhos, Caiobá, Guaratuba, Ilha do Mel, etc., sobre os quais se situam as vilas balneárias mais importantes.

A restinga é formação muito pobre do ponto de vista agrícola. Análises realizadas no Instituto de Biologia e Pesquisas Tecnológicas de Curitiba revelaram o seguinte resultado sumário:

\begin{tabular}{|c|c|c|}
\hline & Amostra $n^{0} 1$ & Amostra $n^{\circ} 2$ \\
\hline Perda ao rubro ..................... & $2,26 \%$ & $0,36 \%$ \\
\hline Nitrogênio total ............... & $0,064 \%$ & $0,064 \%$ \\
\hline Óxido de cálcio ............... & $0,003 \%$ & $0,003 \%$ \\
\hline Óxido de potássio ........... & $0,007 \%$ & $0,008 \%$ \\
\hline Anidrido fosfórico ......... & $0,002 \%$ & $0,002 \%$ \\
\hline Argila & $2,4 \%$ & - \\
\hline
\end{tabular}

Conclusões:

$\begin{array}{ll}\text { Perda ao rubro ........................... } & \text { muito pobre a pobre } \\ \text { Nitrogênio total ........................ } & \text { regular } \\ \text { Óxido de cálcio .................... } & \text { muito pobre } \\ \text { Óxido de potássio ..................... } & \text { muito pobre } \\ \text { Anidrido fosfórico ...................... } & \text { muito pobre }\end{array}$

As amostras 1 e 2 foram coletadas na restinga da praia de Leste, próximo ao Pontal do Sul, a primeira na profundidade de $20 \mathrm{~cm}$ e a segunda a 1 $\mathrm{m}$ de profundidade. A porcentagem da perda ao rubro, na amostra 1, significa um maior teor em matéria orgânica junto à superfície, teor este insignificante.

\section{SEDIMENTAÇÃO INTERMEDIÁRIA}

\section{MANGUEZAL}

Por manguezal (mangrove swamp em inglês, Mangrove Sumpf em alemão) significamos o aspecto geográfico-geológico da formação em si; isto é, a associação vegetal caracterizada por certo número de halófilas, que são designadas indistintamente por mangue, vicejando sobre bancos de lodo nas águas tranqüilas dos rios $\mathrm{e}$ baias.
Os manguezais estendem-se por largas áreas, nas baias de Paranaguá e Guaratuba, penetrando mais ou menos profundamente, nos rios que nelas deságuam e nos rios que vão ter diretamente ao oceano. Constituem ilhas rasas e planas, inundáveis na preamar e emersas na baixa-mar. Bordeiam, em grande extensão, as margens das baias ou dos rios. As ilhas nestas condições possuem, freqüentemente, um centro arenoso com mato ou vegetação de restinga, onde, viceja o Hibiscus tiliaceus L. na zona de transição, e os Cocos romanzofiana nas partes mais centrais. Esta formação arenosa representa muitas vezes um antigo manguezal entulhado por areias e sua flora substituída pela flora de restinga ou mato. Para as formações de manguezal antigo solevado ao nível do mar, seria de conveniência, a introdução de um termo que caracterizasse essa formação. $\mathrm{O}$ termo mangrovito passamos a usar nesta contribuição significando os antigos bancos de manguezal, salvo denominação em contrário.

Entre as espécies constituintes do manguezal paranaense identificamos:

\section{Rhizophora mangle L. \\ Laguncularia racemosa GAERTN. Avicennia tomentosa JACQ.}

E como elemento de transição para a restinga ou mato:

Hibiscus tiliaceus L.

A verificação e a distribuição destas espécies vegetais foram executadas com a colaboração de R. Hertel da Secção de Botânica do Museu Paranaense. RAWITSCHER (1944, p. 25) verificou estas mesmas espécies para os manguezais do Estado de São Paulo. STELLFELD (1945, p. 247).

Característica torna-se a presença em frente aos bosques de mangue de uma gramínea, conhecida regionalmente por "praturá". Segundo fomos informados pelo prof. Dr. F. K. Rawitscher trata-se provavelmente de Spartina brasiliensis RADDI ou $S$. ciliata KUNTH., que são indicadas para tais "habitats"; a falta de flores não possibilitou classificação exata (fig. 46).

FREYBERG (1930), assinala para o norte do Brasil a presença da $S$. brasiliensis. MARTYN (1934) também refere-se à presença dessa gramínea nos manguezais da Guiana Inglesa. À certa distância da barra dos rios vicejam juntamente com o manguezal liliáceas e 
ciperáceas, ocupando a mesma posição do "praturá" (fig. 44).

Nas baias, o manguezal desenvolve-se com maior exuberância nos lugares mais tranqüilos e nas barras dos rios. Não existe ou é escasso nos lugares de correnteza mais forte, onde se encontram praias arenosas, com pequenos barrancos. Observamos maior desenvolvimento do mangue nas regiões lodosas, onde seu desenvolvimento diminui com o aumento do teor de areia, e parece, mesmo, receber decisiva influência da salinidade. Não encontramos mangue, onde é mínimo o teor em sal.

Nos bancos areno-argilosos de sedimentação intermediária tem início o desenvolvimento da flora de manguezal. O banco é primeiramente ocupado por uma gramínea o "praturá" (fig. 45 e 46). Entre as hastes dessa gramínea acumula-se uma pequena quantidade de lodo que favorece a ocupação por mangue. $\mathrm{O}$ mangue edifica-se rapidamente num pequeno bosque, tendendo a um desenvolvimento cada vez maior.

O mangue que aí cresce não é um formador de terra, como pareceria à primeira vista, mas sim um fixador, auxiliando a fixação dos sedimentos, através do seu emaranhado de raízes, podendo contribuir como um acelerador da última fase da sedimentação, necessitando espaços com deposição positiva de sedimentos (FREYBERG, 1930). Esta fixação é débil, sendo que, a ilha ou margem da baia podem ser facilmente destruídas pela erosão motivada pelas ondas ou correntes, sem, contudo, opor grande resistência. O manguezal cede, pouco a pouco, terreno e destruído na sua base de sustentação o mangue acaba por tombar. Nos pontos em que a ação erosiva se fez sentir encontramos diversos espécimes de mangue tombados.

Como já vimos, o mangue não é um formador de terra, porém, acompanha o progresso da deposição do lodo, que se faz no sentido da corrente, na proteção de um ângulo morto ou em direção da água mais salgada.

Nos rios, o manguezal tem seu maior desenvolvimento junto às barras nas baias. Diminui sucessivamente à medida que a salinidade diminui e a correnteza aumenta. É de notar que o mangue se desenvolve ali, de preferência, nas margens convexas, onde a sedimentação se processa, e é mínimo ou nulo nas margens côncavas, onde a correnteza atua mais fortemente. Estas margens apresentam geralmente pequenos barrancos.
Juntamos aqui alguns levantamentos efetuados pelo autor, os quais dão uma idéia da distribuição do manguezal nos rios e baias do litoral paranaense (fig. 11, 12, 13 e 14).

As argilas transportadas pelos rios são floculadas quando em contato com a água salobra, no próprio rio mesmo a algumas dezenas de quilômetros distantes do mar, iniciando ai a sedimentação. A sedimentação entulharia completamente o leito do rio se não fosse a dupla corrente ocasionada pelas marés, que produz a drenagem dos canais dos rios e baias.

Nos rios que deságuam diretamente no oceano, o manguezal tem menor desenvolvimento, porém, apresenta as mesmas características dos rios que deságuam nas baias. Estes últimos, são designados regionalmente por rios de marés.

De maneira geral e esquemática, num manguezal temos em frente bancos de lodo, seguindo-se uma estreita faixa com praturá e imediatamente os bosques de mangue cuja disposição de fora para dentro é aproximadamente a seguinte: Rhizophora, Laguncularia e Avicennia; atrás desta formação, bem delimitada, temos a vegetação de restinga ou mato, com Hibiscus tiliaceus como elemento de transição (fig. 15).

Os nomes vulgares das espécies do manguezal são, na região em estudo, bem definidos e, não encontramos confusão entre as denominações populares:

Rhizophora Mangle = Candapuva ou canapuva (fig. 47).

Laguncularia racemosa = Mangue (fig. 48).

Avicennia tomentosa $=$ Siriuba (fig. 49 e 50).

A denominação popular dos elementos do manguezal já difere no Estado de São Paulo onde encontramos as seguintes denominações:

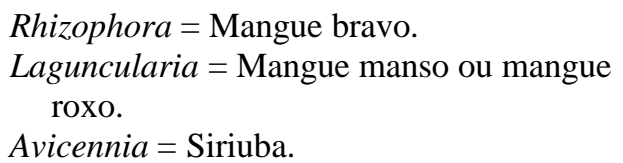

No Estado do Rio de Janeiro, segundo SAMPAIO (19--, p. 107) a denominação corrente dos elementos do manguezal é bastante complicada, existindo grande confusão em torno da denominação vulgar:

Rhizophora $=$ Mangue vermelho ou verdadeiro, guapariba, sapateiro, guaparaiba, mangue de 
pendão, ratimbó, mangarabeira, maparaíga ou canaponga.

Laguncularia $=$ Mangue branco ou cereíba, mangue bravo.

Avicennia $=$ Mangue amarelo, cereibuna ou cereitinga.

A figura 15 mostra a disposição das espécies de mangue no manguezal, onde se pode observar o banco de lodo, o praturá, e os pequenos exemplares de mangue seguidos de maiores e finalmente um verdadeiro mato de mangue (fig. 46). Geralmente o maior porte é alcançado pela Avicennia que se sobressai das demais espécies, podendo ser identificada à distância. A Avicennia é utilizada como combustível; a Rhizophora e a Laguncularia são usadas na preparação do tanino. A grande exploração da Rhizophora, nas baias está modificando o aspecto do manguezal local. Em análises procedidas no Instituto de Biologia e Pesquisas Tecnológicas em Curitiba verificou-se a seguinte porcentagem em tanino:

a) Cascas de Rhizophora Mangle do rio Emboguaçú na baia de Paranaguá:

$\begin{array}{lll}\text { Umidade }\left(100-105^{\circ} \mathrm{C}\right) & \ldots \ldots \ldots \ldots \ldots \ldots \ldots \ldots . . . & 52,10 \% \\ \text { Tanino curtiente ............................. } & 6,58 \% \\ \text { Tanino não curtiente ….................. } & 2,94 \%\end{array}$

b) Folhas de Laguncularia racemosa da baia de Guaratuba:

$\begin{array}{lll}\text { Umidade }\left(100-105^{\circ} \mathrm{C}\right) & \ldots \ldots \ldots \ldots \ldots \ldots \ldots \ldots . . . & 65,40 \% \\ \text { Tanino curtiente ............................. } & 7,36 \% \\ \text { Tanino não curtiente ...................... } & 1,84 \%\end{array}$

Em frente aos manguezais há um banco de lodo fofo de coloração variável, que vai do cinzento claro ao castanho escuro, que é ocasionada principalmente pelo teor de matéria orgânica (fig. 46). No interior do manguezal encontram-se freqüentemente, poças de água salobra, que, nos dias muito secos e quentes, podem depositar finíssima camada de sais. Para o interior do manguezal o solo torna-se mais firme $\mathrm{e}$ sucessivamente mais arenoso, possibilitando o fácil deslocamento de uma pessoa, isto facilitado em grande parte pelo emaranhado de raízes e pneumatóforos.

Em consequiência da ação das correntes, freqüentemente $o$ manguezal apresenta uma margem bastante inclinada; nesse caso não temos um banco de lodo que emerge na baixa-mar assim como não temos a Spartina situada em frente às espécies de mangue, salvo casos em que é escassamente representada por alguns indivíduos.

A espessura de um banco de manguezal está estreitamente ligada à diferença das marés, não ultrapassando $2 \mathrm{~m}$. esta espessura é modificada durante os movimentos epirogênicos, na ascensão sua possança é diminuída e aumentada em caso de afundamento.

A paisagem de uma região de manguezal não é perene, mas sim em constante modificação. Durante as enchentes da preamar são depositadas sobre os manguezais, areias finíssimas com uma porcentagem máxima de grãos compreendidos entre 0,062 e $0,125 \mathrm{~mm}$, conforme tivemos ocasião de observar na ilha do Boleado na baia de Guaratuba (fig. 18). Tais areias, assim depositadas, tornam o banco de manguezal cada vez mais arenoso, provocando a morte do mangue. Esse processo de entulhamento avança juntamente com o progresso do manguezal. Nessa zona tem início o desenvolvimento do Hibiscus tiliaceus, que se comporta como elemento de transição para a flora de restinga ou mato. Também areias eólicas são depositadas sobre o manguezal, sendo aqui a sua importância secundária.

Pelos movimentos epirogênicos, bancos de manguezal foram alçados sobre o nível do mar, deixando de receber água salobra, e, em consequiência, causando a morte das espécies de mangue. Estes bancos já arenosos pelo processo de entulhamento com areias marinhas no interior das baias, formam taboleiros com diferentes altitudes sobre o nível atual do mar, constituindo o mangrovito. Muitas vezes regiões de manguezal são transformadas em pantanais terrestres, hoje não mais sofrendo a ação das marés. Muitas regiões pantanosas desse tipo são encontradas no litoral do Estado do Paraná, entre elas citamos trechos da praia de Leste.

A distribuição das diferentes espécies de mangue parece não obedecer regra geral. Referente à Rhizophora, a sua distribuição atual foi muito modificada pela intervenção humana. Segundo informações e verificações próprias pudemos estabelecer os seguintes pontos mais característicos onde esta espécie vegetal é ou foi dominante: região do rio Itiberê até o rio Guaraguaçú, em diferentes lugares da baia de Antonina e Laranjeiras; no rio Fundo e regiões adjacentes (hoje quase totalmente explorado), na baia de Guaratuba. E segundo nossas verificações, concluímos ser na baia de Paranaguá o seu 
desenvolvimento maior. A Avicennia encontramos com seu maior desenvolvimento, na ilha da Sepultura e num trecho do rio Fundo, na baia de Guaratuba; é muito difundida nos manguezais, juntamente com a Laguncularia. A Laguncularia é a espécie de mangue mais desenvolvida pelo número de indivíduos no litoral paranaense. Lugares há onde encontramos as três espécies igualmente distribuídas, geralmente com a Rhizophora em frente seguida da Laguncularia e Avicennia; esta última se destaca pelo seu porte. No rio Saí-Guaçú temos a predominância da Laguncularia, seguida da Avicennia com número bem menor de indivíduos e finalmente a Rhizophora com número restrito de exemplares:

\section{Laguncularia -- Dominante \\ Avicennia - Média \\ Rhizophora - Mínima}

No rio Perequê, no Pontal do Sul, verificamos a seguinte disposição da flora de manguezal: nas imediações da barra e curso mais inferior verificamos a presença de muitos indivíduos de Rhizophora juntamente com Laguncularia e Avicennia, mais para cima até $2 \mathrm{~km}$ a $3 \mathrm{~km}$ da foz, encontramos a Laguncularia com número bem menor de exemplares de Rhizophora. A Avicennia limitou-se às partes médias e inferior do curso do rio com manguezal e situa-se sempre atrás das outras espécies. Em vista do número relativamente pequeno de observações, não consideramos esta distribuição como regra bem definida.

No litoral do Paraná verificamos, de maneira ainda muito generalizada a seguinte distribuição das espécies do manguezal:

\section{Laguncularia-- Dominante \\ Avicennia - Média \\ Rhizophora - Pequena}

Na excursão realizada em setembro de 1946 ao Estado de Santa Catarina, tivemos ocasião de percorrer os manguezais da ilha de Santa Catarina, onde verificamos a dominância absoluta da Avicennia sobre as demais espécies na paisagem do manguezal. Poucos foram os exemplares de Rhizophora observados. Esquematicamente tivemos na ilha de Santa Catarina a seguinte distribuição:

\footnotetext{
Avicennia-- Dominante

Laguncularia - Média

Rhizophora - Mínima
}

O manguezal diminui rapidamente para o sul deste Estado. Não podemos precisar o limite sul dessa associação vegetal. Segundo informação verbal do Dr. R. Maack ainda existe mangue na foz do rio Araranguá, ponto mais ao sul do litoral catarinense por nós percorrido. STEELFIED (1945, p. 246), baseado em MOLDENKE, cita a seguinte distribuição geográfica para a Avicennia Schaueriana ou A. tomentosa, desde a Martinica e Granada até o Brasil Meridional e Uruguai.

\section{BANCOS ARENO-ARGILOSOS, SAMBAQUIS E MANGROVITOS}

$\mathrm{O}$ interior da lagoas ou baias apresenta o desenvolvimento de bancos de sedimentos arenoargilosos, de granulação fina, depositados em águas tranqüilas (fig. 19). São em geral sedimentos com maior porcentagem de grãos finos do que os sedimentos de restinga. Possuem coloração variável, amarelo, cinzento, castanho claro e às vezes castanho escuro devido a maior porcentagem de matéria orgânica.

Nos bancos areno-argilosos do ambiente de sedimentação em águas tranquiilas do interior das baias ou lagoas desenvolve-se uma associação de moluscos característica, constituída de diversas espécies entre as quais destacamos a Anomalocardia brasiliana GML. Tivemos oportunidade de observar em alguns baixios que emergem durante a baixa-mar, a existência de agrupamentos desses moluscos mergulhados na areia ou lodo.

Esses baixios formados por bancos de sedimentos areno-argilosos, quando alçados sobre o nível do mar, apresentam-se primeiramente como terrenos úmidos, passando posteriormente a formar taboleiros arenosos através de uma maior concentração de grãos de areia junto à superfície. Os agrupamentos de moluscos elevados sobre o nível do mar nessas condições são rapidamente destruídos pela ação química do meio, produzindose a dissolução e livigação do carbonato de cálcio constituinte das valvas animais. Os antigos bancos de lodo e areia apresentam um teor de cálcio pouco maior do que o apresentado pelas formações arenosas de restinga:

$\begin{array}{ll}\text { Bancos arenosos do interior das baias...... } & 0,010 \% \text { de } \mathrm{CaO} \\ \text { Formações arenosas de restinga } . . . . . . . . . . . . & 0,003 \% \text { de } \mathrm{CaO}\end{array}$

A análise sumária dos solos dessa formação, realizada no Instituto de Biologia e Pesquisas 
Tecnológicas de Curitiba revelou o seguinte resultado:

$\begin{array}{ll}\text { Perda ao rubro } & 1,76 \% \\ \text { Nitrogênio total } & 0,064 \% \\ \text { Óxido de cálcio } & 0,010 \% \\ \text { Óxido de potássio } & 0,007 \% \\ \text { Anidrido fosfórico } & 0,002 \%\end{array}$

Conclusões:

$\begin{array}{ll}\text { Perda ao rubro } & \text { Pobre } \\ \text { Nitrogênio total } & \text { Regular } \\ \text { Óxido de cálcio } & \text { Pobre } \\ \text { Óxido de potássio } & \text { Muito pobre } \\ \text { Anidrido fosfórico } & \text { Muito pobre }\end{array}$

Trata-se de terrenos agricolamente muito pobres, semelhantes aos de restinga.

Nos rios Boguaçú e Praia (fig. 11) encontramos nas margens côncavas, bancos areno-argilosos situados a cerca de $1 \mathrm{~m}$ a $1,3 \mathrm{~m}$ sobre o nível médio do rio (aproximadamente igual ao nível médio do mar), contendo intercalada uma camada de $0,3 \mathrm{~m}$ a $0,4 \mathrm{~m}$ de espessura de pelecípodos e gasterópodos, na forma de valvas inteiras e fragmentadas (fig. 17 e 51). O material malacológico por nós coletado e gentilmente determinado pelo prof. Barão Otorino de Fiori, é constituído pelas seguintes espécies, ainda hoje viventes no interior de nossas baias:

Anomalocardia brasiliana GML.
Dosinia concentrica BORN
Cerithium striatissimun SOWASKY
Massa poligonata STR.
Thais cornuta ? Menke
Laevicardium renatum L.
Semele reticulata L.
Macoma constricta BRUES.
Chicoreus senegalensis GM.
Plicatula sp.
Arca incongrua SAY.
Cyclinella tenuis RECLUS.
Bullaria striata BRUS.

O material coletado rapidamente, não representa o total das espécies aí existentes, entretanto dá uma idéia sobre a fauna desse ambiente. Esse material sub-fossil apresenta-se muito corroído pela ação do ácido húmico. Essa camada de restos de moluscos pertenceu sem dúvida a um velho agrupamento de moluscos, hoje solevado sobre o nível do mar.

Relacionamos a ocorrência desses agrupamentos de moluscos com a situação dos sambaquis, que se acham atualmente em diferentes altitudes sobre o nível do mar, representando essas alturas diversas idades da construção dos mesmos pela atividade humana. Os sambaquis até agora visitados são de origem artificial e constituídos de elementos da fauna do interior das baias ou lagoas, com exceção dos construídos sobre afloramentos rochosos do complexo cristalino, como tivemos ocasião de verificar no rio Nhundiaquara entre Morretes e Antonina, os quais são constituídos por outras espécies de ostreas ${ }^{5}$ e, contendo também muitas vezes espinhos de peixe e esqueletos humanos. A construção dos sambaquis (aqui referimo-nos principalmente aos construídos por elementos da fauna do interior das baias) foi condicionada a um agrupamento de moluscos. Sua idade relativa deveria ser estabelecida em relação à sua localização nos diferentes bancos de sedimentos. A distância que os separa do mar nem sempre estabelece uma relação de idade. No rio Boguaçú (fig. 11), considerando a posição estratigráfica dos sambaquis da Barra Velha e do Boguaçú (margem direita), verificamos que o último é mais antigo que o primeiro, embora este esteja situado mais para o interior.

KRONE (1908, p. 23 e segs.), estudando os sambaquis do curso inferior do rio Ribeira, distinguiu sambaquis antiquiíssimos e modernos, e recomenda para sua distinção a maior observância possível à sua posição topográfica. O mesmo autor (p. 31) verificou que a base do sambaqui sempre assenta em chão firme e nunca abaixo do nível do mar, alguns são atingidos pelas águas na preamar; outros se situam a maiores altitudes. Nossas verificações estão em acordo com as verificações de KRONE no que diz respeito, principalmente, à relação da base do sambaqui com o nível do mar.

Os sambaquis distribuem-se em estreita ligação com os antigos agrupamentos de moluscos existentes nos baixios e bancos areno-argilosos. A construção dos sambaquis sem dúvida foi efetuada sobre um desses agrupamentos ou nas suas vizinhanças imediatas. A forma destes, bem delimitada e alta, deve-se provavelmente a uma precaução do homem malacófago, construtor do sambaqui, em ajuntar as cascas em montes, afim de evitar a inutilização do agrupamento de moluscos deixando as cascas abandonadas alhures,

\footnotetext{
${ }^{5}$ Nos sambaquis com base arenosa, na planície, é encontrada principalmente a Ostrea brasiliana, em contraste com os sambaquis construídos sobre rochas onde se encontra em geral a Ostrea virginica.
} 
o que não só dificultaria de grande modo a coleta de moluscos como também perturbaria o desenvolvimento do agrupamento (fig. 52).

As diferentes situações de sambaquis requerem estudos mais minuciosos da sua posição em relação aos bancos de sedimentos e também da sua constituição faunística e arqueológica, estudos que, sistematizados, trarão mais luz sobre a préhistória brasileira. Seria de grande interesse histórico que o governo fizesse executar a legislação em vigor, de modo a assegurar a conservação de alguns desses típicos monumentos arqueológicos construídos pelo homem préhistórico do Brasil.

Em consequiência do movimento positivo da região, os bancos areno-argilosos, formados no interior das baias e lagoas, foram solevados sobre o nível atual do mar, apresentando-se como taboleiros arenosos de altura mais ou menos uniforme, marcando certos níveis na região, entre os quais salientamos os de $10 \mathrm{~m}, 7 \mathrm{~m}, 3,5 \mathrm{~m}$ e $1,3 \mathrm{~m}$. Distingue-se da restinga, morfologicamente, pela largura e irregularidade de contorno. Nesses taboleiros, como nos encontrado no rio Saí-Guaçú, em Boa Vista, Soares e Boguaçú, observam-se vales de aspecto semelhante aos vales de restinga.

Freqüentemente, os bancos claros de sedimentos areno-argilosos são capeados por uma camada de cerca de $2 \mathrm{~m}$ de espessura de areias escuras, compactas, representando um antigo manguezal. Essa camada é conhecida regionalmente pelo nome de "piçarra". Registramos para essa camada característica a denominação de mangrovito, em virtude da sua correlação com os manguezais antigos. Justificamos o nome de mangrovito para este tipo de sedimentos em virtude dos mesmos constituírem um depósito típico e característico, embora ainda não tenham sofrido a diagênese, e considerando que em geologia, qualquer depósito clástico, ainda que, não consolidado seja considerado uma rocha.

Os bancos de lodo podem ou não ser colonizados pelo mangue; em caso positivo temos o manguezal no sentido geológico-geográfico da palavra. Biologicamente como já vimos, a existência e a espessura do banco de manguezal são condicionadas aos níveis da baixa-mar e preamar; sendo que a espessura do banco de manguezal não é superior à diferença entre esses níveis. $\mathrm{O}$ manguezal migra sempre em direção à água mais salobra, e vai perecendo do lado oposto em consequiência do entulhamento por sedimentos arenosos, que transforma o banco de lodo primitivo, tornando-o cada vez mais arenoso, assim como pela falta de água salgada. Esses bancos, quando alçados sobre o nível do mar, após o desaparecimento do manguezal, tem o aspecto de um "arenito" escuro estratificado e friável mangrovito -, não se desfazendo em contato com a água. Verificamos esta propriedade em diversos pontos nas baias de Paranaguá e Guaratuba, onde encontramos blocos mergulhados na água das baias, sofrendo a influência das ondas e das marés (fig. 53 e 54). Contém escassos restos de moluscos e restos de vegetais semi-carbonizados. Apresentam-se com espessura não muito superior à diferença entre os níveis da baixa-mar e preamar. Representam, pois, o nível do mar em que foram formados.

TWENHOFEL (1939, p. 76-77), referindo-se ao ambiente de sedimentação paludal-marinha, em condições estacionárias do nível do mar indica para essas condições um depósito com o máximo de $6 \mathrm{~m}$ de espessura; notando ainda que, camadas escuras seriam comuns no primeiro estágio dos pantanais marinhos - no presente caso os manguezais.

Em Piçarras, localidade típica situada a cerca de 2 $\mathrm{km}$ a oeste da vila de Guaratuba (fig. 11), ocorre um banco de sedimentos arenosos marrons escuros constituído de um "arenito friável" que não se desfaz, todavia, ao contato da água. Contém raros restos de moluscos e raízes vegetais parcialmente carbonizadas. Situa-se a uma altitude de 3,5 m. É indiscutivelmente, um antigo banco de manguezal, hoje solevado a $3,5 \mathrm{~m}$ sobre o nível do mar. A superfície é formada por uma camada de cerca de $0,2 \mathrm{~m}$ de areias claro-cinzentas, descoradas pela ação de ácido húmico e águas pluviais. Segue-se outra camada, com $2 \mathrm{~m}$ de possança, de areias escuras e compactas - mangrovito -. Abaixo dessa camada ocorrem areias amarelas de espessura desconhecida (fig. 53).

Bancos semelhantes em Cananéia, Estado de São Paulo, são descritos por LEONARDOS (1938, p. 24), que os tem, como depósitos eólicos. OLIVEIRA e LEONARDOS (1943, p. 764-765) consideram tais bancos como produtos da sedimentação eólica ou sedimentação de vazante. A sua formação não nos parece eólica, mas, representaria antigos bancos de manguezal, cobertos primeiramente pelas areias marinhas e posteriormente pelas areias eólicas. Apresenta composição granulométrica diferente da do depósito eólico (fig. 20 e 21). No manguezal da 
ilha do Boleado, na baia de Guaratuba, ocorre, em muitos lugares, fina camada de areias brancas cuja composição granulométrica é semelhante aos antigos bancos de manguezal, solevados sobre o nível do mar.

A análise química dos bancos de manguezal antigo - mangrovito -, realizada nos Laboratórios do Instituto de Biologia e Pesquisas Tecnológicas de Curitiba por L. J. Weber e A. Leprevost revelou o seguinte resultado:

A análise refere-se a material seco a $110^{\circ} \mathrm{C}$

$\begin{array}{ll}\text { Sílica - } \mathrm{Sio}^{2} & \begin{array}{l}91,46 \% \\ \text { traços }\end{array} \\ \text { Óxido de titânio - } \mathrm{TiO}^{2} & 2,13 \% \\ \text { Óxido de alumínio - } \mathrm{Al}^{2} \mathrm{O}^{3} & 0,11 \% \\ \text { Óxido férrico - } \mathrm{Fe}^{3} \mathrm{O}^{3} & 0,26 \% \\ \text { Óxido ferroso - } \mathrm{FeO} & 0,04 \% \\ \text { Óxido de manganês - } \mathrm{MnO} & 0,25 \% \\ \text { Óxido de magnésio - } \mathrm{MgO} & 0,75 \% \\ \text { Óxido de cálcio - } \mathrm{CaO} & 0,27 \% \\ \text { Óxido de sódio - } \mathrm{Na}{ }^{2} \mathrm{O} & 0,55 \% \\ \text { Óxido de potássio - } \mathrm{K}^{2} \mathrm{O} & 0,92 \% \\ \text { Água combinada - } \mathrm{H}^{2} \mathrm{O} & 0,92 \% \\ \text { Anidrido fosfórico - } \mathrm{P}^{2} \mathrm{O}^{5} & 0,02 \% \\ \text { Anidrido sulfúrico - } \mathrm{SO}^{3} & \text { negativo } \\ \text { Enxofre - S } & \text { negativo } \\ \text { Anidrido carbônico - } \mathrm{CO}^{2} & \text { negativo } \\ \text { Perda ao fogo } & 2,88 \% \\ \text { Óxido de bário - } \mathrm{BaO} & \text { negativo } \\ \text { Óxido de níquel - } \mathrm{NiO} & \text { negativo } \\ \text { Cloro - } \mathrm{Cl} & 0,62 \%\end{array}$

A análise química do mangrovito revela uma rocha rica em sílica e pobre em argila e outros elementos químicos.

Uma amostra de água coletada num pequeno poço, no Pontal do Sul, aberto em sedimentos escuros de mangrovito, revelou em análise procedida nos laboratórios do Instituto de Biologia e Pesquisas Tecnológicas em Curitiba, por R. Spitzner e J. Ravaglio o seguinte resultado:

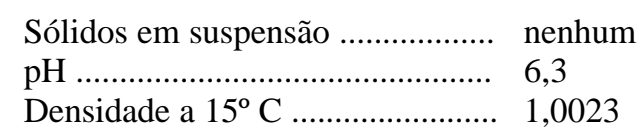

Resultado por litro de água não filtrada:

Resíduo de evaporação a $110^{\circ} \mathrm{C}$

Resíduo volátil

Resíduo fixo

Matéria orgânica (meio ácido)

Oxigênio consumido (meio alcalino)

\begin{tabular}{|c|c|}
\hline Nitrogênio amoniacal em $\mathrm{NH}^{5}$ & nenhum \\
\hline Nitrogênio albuminóide em $\mathrm{NH}^{5}$ & nenhum \\
\hline Nitritos em $\mathrm{NO}^{2}$ & nenhum \\
\hline Nitratos em $\mathrm{NO}^{5}$ & nenhum \\
\hline Sílica - $\mathrm{SiO}^{2}$ & $0,0058 \mathrm{~g} \%$ 。 \\
\hline $\begin{array}{l}\text { Óxidos de ferro e alumínio - } \\
\mathrm{Fe}^{2} \mathrm{O}^{5} \mathrm{e}^{2} \mathrm{O}^{3}\end{array}$ & $0,0001 \mathrm{~g} \mathrm{\%}$ \\
\hline Óxido de calico - $\mathrm{CaO}$ & $0,0028 \mathrm{~g} \%$ 。 \\
\hline Óxido de magnésio - MgO & $0,0028 \mathrm{~g} \mathrm{\%}$ \\
\hline Potássio - K & $0,0007 \mathrm{~g} \%$ 。 \\
\hline Sódio - Na & $0,0065 \mathrm{~g} \%$ 。 \\
\hline Cloro - Cl & $0,0106 \mathrm{~g} \mathrm{\%}$ \\
\hline Gás sulfídrico $-\mathrm{H}^{2} \mathrm{~S}$ & nenhum \\
\hline Sulfatos $-\mathrm{SO}^{4}$ & $0,0041 \mathrm{~g} \%$ 。 \\
\hline Gás carbônico - $\mathrm{CO}^{2}$ & $0,0250 \mathrm{~g} \%$ 。 \\
\hline Bicarbonatos $-\mathrm{HCO}^{3}$ & $0,0183 \mathrm{~g} \%$ 。 \\
\hline Carbonatos $-\mathrm{CO}^{3}$ & nenhum \\
\hline Dureza total em graus franceses & $0,5^{\circ}$ \\
\hline
\end{tabular}

Composição provável:

$\begin{array}{ll}\text { Sulfato de cálcio - } \mathrm{CaSO}^{4} & 0,0058 \mathrm{~g} \% \text { } \\ \text { Bicarbonato de cálcio - } \mathrm{Ca}\left(\mathrm{HCO}^{3}\right)^{2} & 0,0012 \mathrm{~g} \% \\ \text { Bicarbonato de magnésio }-\mathrm{Mg}\left(\mathrm{HCO}^{3}\right)^{2} & 0,0096 \mathrm{~g} \% \\ \text { Bicarbonato de sódio }-\mathrm{NaHCO} & 0,0132 \mathrm{~g} \% \\ \text { Cloreto de sódio }-\mathrm{NaCl} & 0,0073 \mathrm{~g} \% \text { 。 } \\ \text { Cloreto de potássio }-\mathrm{KCl} & 0,0070 \mathrm{~g} \% \text { 。 }\end{array}$

Trata-se de água potável, recomendando-se o controle bacteriológico em virtude do alto teor em matéria orgânica.

\section{SEDIMENTAÇÃO TERRÍGENA}

\section{ALUVIÃO TERRESTRE}

Nas proximidades e nas encostas do complexo cristalino, observam-se depósitos de piemonte. O clima tropical, favorecendo, de maneira notável, a decomposição das rochas, ocasiona a formação de camadas de decomposição relativamente grandes. Em consequiência da forte inclinação da topografia do complexo cristalino ocorre, muitas vezes, por ocasião de grandes chuvas, o desmoronamento de uma dessas camadas de decomposição, originando cores de detritos - piemonte. Os habitantes do litoral denominam de "rolados" tais desmoronamentos, ocorridos na zona do desmonte. Os depósitos de aluvião terrestre de origem fluvial, apresentam-se como taboleiros, ocorrendo mais para o interior da planície litorânea. Como exemplo notável dessa formação citamos a planície aluvial de Morretes (fig. 55). Os taboleiros apresentam-se planos, constituídos de sedimentos em sua maioria de granulação fina com 
grande porcentagem de argila (fig. 24). Situam-se a uma certa altura sobre o nível do rio, e são sujeitos a inundações periódicas. $\mathrm{O}$ seu desenvolvimento mais importante situa-se mais para o interior da planície, junto aos rios maiores. A planície aluvial de Morretes acha-se a $10 \mathrm{~m}$ de altitude sobre o nível do mar, é cortada pelo rio Nhundiaquara e seus afluentes. Os rios que cortam a planície de aluviões terrestres tem o seu curso meandrante, o leito freqüentemente com seixos em contraste com o curso mais inferior também meandrante, porém, com leito arenoso. Entre os taboleiros de aluvião terrestre ocorrem pântanos e brejos. Representam juntamente com a zona da encosta e os solos do complexo cristalino os terrenos mais ricos para a agricultura regional. $\mathrm{O}$ homem do litoral, habitante da restinga geralmente tem sua roça nos terrenos de aluvião terrestre, nos taboleiros mais interiores ou na zona das encostas do complexo cristalino.

As baixadas situadas entre as formações arenosas apresentam-se geralmente pantanosas e inabitáveis. São cobertas com mata muitas vezes rica em palmáceas. O solo escuro é bastante turfoso e ainda não consolidado, apresentando-se como um atoleiro muitas vezes intransitável. Os habitantes da região estivam com troncos de árvores os pântanos, e ao caminho, assim obtido, denominam "caminho de estiva", utilizam também as pinguelas. Sondagens realizadas com trado revelaram profundidades superiores a $10 \mathrm{~m}$. Essas baixadas pantanosas são constituídas quase que exclusivamente de argilas cinzentas; são representantes de antigas lagoas atualmente quase completamente entulhadas ou em processo avançado de entulhamento.

Análises de argilas de Alexandra, no município de Paranaguá realizadas no Instituto de Biologia e Pesquisas Tecnológicas de Curitiba, revelaram a seguinte composição química:

$\begin{array}{lrr} & \text { Análise no 1 } & \text { Análise no 2 } \\ \text { Perda ao rubro } & 10,30 \% & 10,97 \% \\ \text { Sílica }-\mathrm{SiO}^{2} & 56,88 \% & 53,76 \% \\ \text { Óxido de férrico }-\mathrm{Fe}^{2} \mathrm{O}^{3} & 6,72 \% & 4,14 \% \\ \text { Óxido de alumínio }-\mathrm{Al}^{2} \mathrm{O}^{3} & 25,28 \% & 30,84 \% \\ \text { Óxido de cálcio - } \mathrm{CaO} & 1,00 \% & 0,10 \% \\ \text { Óxido de magnésio - } \mathrm{MgO} & 1,66 \% & 0,28 \% \\ \text { Óxido de manganês - } \mathrm{MnO} & \text { negativo } & \text { negativo }\end{array}$

Os pantanais antigos apresentam superfície escura, e são muitas vezes constituídos de material turfoso. Têm na base sedimentos marinhos de coloração clara. Esporadicamente encontramos na região pantanosa, rios ou riachos de águas escuras e de pouca velocidade. Essas regiões não sofrem mais a ação das marés. As vezes observam-se pequenas lagoas marginais aos rios $\mathrm{e}$ completamente cobertas com vegetação típica de brejo; perí-perí (Cíperus princeps), etc. ao oeste do Taboleiro, na região Matinhos-Caiobá, temos um exemplo do entulhamento de uma lagoa pelo aluvião terrestre proveniente das encostas do complexo cristalino (fig. 7). Sucessivamente, todos os depósitos marinhos são, cobertos pelos depósitos continentais.

Os vales de restinga apresentam-se úmidos ou pantanosos, de modo a permitir o desenvolvimento de uma flora distinta da flora de restinga. Muitas vezes apresentam-se largos e tem no seu interior um riacho ou pequenas lagoas estreitas de água doce. Quando o riacho sofre a ação das marés temos o desenvolvimento do mangue. A ação dos ventos contribui para o nivelamento das restingas, preenchendo os vales com sedimentos eólicos, entulhando esses pequenos pântanos.

\section{DUNAS EÓLICAS}

A ação dos ventos no litoral paranaense faz-se sentir de maneira menos intensa que em outros pontos do litoral brasileiro, quer do norte ou do sul, onde ocorre um maior desenvolvimento das dunas. Em excursão realizada ao Estado de Santa Catarina, verificamos na foz do rio Araranguá, um campo de dunas bem desenvolvidas, no qual as dunas chegam a atingir cerca de $30 \mathrm{~m}$ de altura (MAACK, 1937, p. 72-74 e mapa anexo). Dunas menores notamos na ilha de Santa Catarina, verificando um decréscimo de altura à medida que avançamos para $\mathrm{o}$ norte onde $\mathrm{o}$ seu desenvolvimento é relativamente pequeno. No litoral paranaense e paulista, as dunas, geralmente, não ultrapassam $7 \mathrm{~m}$ de altura (fig. 58).

A granulação das areias eólicas das dunas é bastante fina e uniforme. Em diferentes análises granulométricas, realizadas em sedimentos eólicos de dunas, entre o Estado de São Paulo (Itanhaen) e o Estado de Santa Catarina (Araranguá), verificamos que a porcentagem dominante se situa entre os diâmetros 0,125 e $0,250 \mathrm{~mm}$. A granulação mais fina é representada por maior porcentagem de ilmenita. Notamos porcentagem maior de grãos mais grossos nas dunas eólicas do que nas areias das praias que lhes ficam em frente, indicando esse fato que os grãos mais finos são transportados a maior distância fora do campo das 
dunas, passando os mais grossos a constituir as dunas (fig. 21, 22 e 23).

A seguinte tabela organizada com dados de CARVALHO (1930, p. 88) dá uma idéia da freqüência dos ventos em Paranaguá no litoral paranaense:

\begin{tabular}{l|c}
\hline Meses & Freqüência \\
\hline Janeiro & SSE \\
Fevereiro & SSE \\
Março & SE \\
Abril & SE \\
Maio & NNW \\
Junho & SSE \\
Setembro & SSE \\
Outubro & SE \\
Novembro & NE \\
Dezembro & NE \\
\hline
\end{tabular}

Faltam dados sobre os meses de julho e agosto.

As pequenas dunas junto à praia tem a forma de pequenos montículos que adquirem maior desenvolvimento mais para o interior, podendo atingir 3 ou $4 \mathrm{~m}$ de altura. São móveis e não apresentam a forma característica das dunas. Avançam sobre a restinga em forma de cunhas (fig. 57) soterrando e asfixiando a vegetação baixa de restinga. Geralmente são cobertas com a vegetação das ante-dunas: Ipomoea pés caprae, Remirea maritima, Salicornea, gramíneas, ciperáceas, etc. (fig. 40).

Paralelamente à praia nota-se um cordão de dunas já fixas, cuja altitude não ultrapassa de $7 \mathrm{~m}$. Esta forma ondulada na topografia da restinga é denominada regionalmente de cômoros. Os cômoros têm estrutura eólica típica, ainda que muito perturbada pela inconstância dos ventos. A figura 56 mostra a estrutura de uma duna no Pontal do Sul. A ação dos ventos tende ao nivelamento da planície de restinga, entulhando os vales e desgastando os cômoros. Transforma-lhes assim, o aspecto original.

\section{COEFICIENTE DE SELEÇÃO DOS SEDIMENTOS DO LITORAL PARANAENSE}

Nas análises mecânicas realizadas pelo autor nos laboratórios do Instituto de Biologia e Pesquisas Tecnológicas de Curitiba, os diferentes tamanhos dos grãos foram separados por um jogo de peneiras automáticas, segundo a classificação de Wentworth. Com os dados assim obtidos construímos os histogramas que ilustram o presente trabalho. Para o cálculo de Fi adotamos o diâmetro médio das peneiras. $\mathrm{Na}$ transformação da escala em milímetros para a escala Fi de Krumbein aplicamos a seguinte fórmula:

$$
\mathrm{Fi}=\frac{\operatorname{colg} \mathrm{E}}{\log 2} \quad \text { ou } \quad \mathrm{Fi}=3.32 \times \operatorname{colg} \mathrm{E}
$$

sendo E o diâmetro médio da classificação de Wentworth.

Obtivemos aplicando esta fórmula o seguinte resultado, dado pela tabela abaixo.

\begin{tabular}{l|rrr}
\hline \multirow{2}{*}{ E mm } & \multirow{2}{*}{ Colg E } & \multicolumn{2}{|c}{ Fi } \\
\cline { 3 - 4 } & & Calculado & \multicolumn{1}{c}{ Aprox. } \\
\hline 1,5 & $-0,176$ & $-0,390$ & $-0,4$ \\
0,75 & 0,125 & 0,415 & 0,5 \\
0,375 & 0,426 & 1,404 & 1,5 \\
0,187 & 0,728 & 2,417 & 2,5 \\
0,093 & 1,032 & 3,426 & 3,5 \\
0,031 & 1,509 & 5,009 & 5 \\
\hline
\end{tabular}

Partindo destes dados construímos as curvas cumulativas dos sedimentos litorâneos na escala aritmética (fig. 26), utilizando-nos das freqüências acumuladas da tabela seguinte:

\begin{tabular}{|c|c|c|c|c|c|c|c|}
\hline $\mathbf{F i}$ & & $-0,4$ & 0,5 & 1,5 & 2,5 & 3,5 & 5,0 \\
\hline \multirow[t]{2}{*}{ Depósito praial } & A & 0,0 & 0,0 & 0,25 & 67,75 & 99,25 & 100,0 \\
\hline & B & 0,0 & 0,05 & 24,55 & & & \\
\hline Bancos de sed. & & 0,0 & 0,0 & 2,0 & & & 0,0 \\
\hline Intermediáric & $\mathrm{D}$ & 0,0 & 4,0 & 11,50 & & & 100,0 \\
\hline \multirow[t]{2}{*}{ Mangrovito } & E & 0,0 & 0,0 & 0,05 & 42,75 & & 100,0 \\
\hline & F & & 0,0 & 4,00 & & & 100,0 \\
\hline Duna & G & & 0,1 & 12,50 & 94 & & -- \\
\hline Aluvião te & $\mathrm{H}$ & 0,0 & 0,0 & 3,50 & 13,50 & 41,00 & 100,0 \\
\hline $\begin{array}{l}\text { Antigo es } \\
\text { marinho }\end{array}$ & I & 0,0 & 12,5 & 58,00 & 87,00 & 92,00 & 100,0 \\
\hline
\end{tabular}

Do gráfico da fig. 26 extraímos os valores dos desvios aritméticos dos quartéis na escala $\mathrm{Fi}$, QDFi - segundo a fórmula:

$$
\mathrm{QDFi}=\frac{\mathrm{Q} 3 \mathrm{Q} 1}{2}
$$

Para o cálculo do logaritmo da seleção $\left(\log \mathrm{S}_{\mathrm{o}}\right)$, aplicamos a fórmula seguinte:

$$
\log \mathrm{S}_{\mathrm{o}}=\log 2 \times \mathrm{QDFi}
$$

Utilizando esta fórmula obtivemos o resultado abaixo: 


\begin{tabular}{l|rrrrrr|r}
\hline & \multicolumn{5}{|c|}{ Valores em escala Fi } & \multirow{2}{*}{ Log $\mathrm{S}_{\mathrm{o}}$} & \multirow{2}{*}{$\mathrm{S}_{\mathrm{o}}$} \\
\cline { 2 - 5 } & \multicolumn{1}{|c}{$\mathrm{Q}_{3}$} & \multicolumn{1}{c}{$\mathrm{Q}_{1}$} & \multicolumn{1}{c}{ Dif. } & Média & & \\
\hline $\mathrm{A}$ & 2,650 & 1,775 & 0,875 & 0,437 & 0,1315 & 1,354 \\
$\mathrm{~B}$ & 2,2 & 1,525 & 0,6 & 0,337 & 0,1014 & 1,263 \\
$\mathrm{C}$ & 2,95 & 1,92 & 1,03 & 0,515 & 0,1550 & 1,429 \\
$\mathrm{D}$ & 3,25 & 2,02 & 1,23 & 0,615 & 0,1851 & 1,532 \\
$\mathrm{E}$ & 3,1 & 2,08 & 1,02 & 0,510 & 0,1535 & 1,424 \\
$\mathrm{~F}$ & 2,45 & 1,8 & 0,67 & 0,325 & 0,0978 & 1,253 \\
$\mathrm{G}$ & 2,27 & 1,55 & 0,72 & 0,36 & 0,1084 & 1,284 \\
$\mathrm{H}$ & 4,35 & 2,9 & 1,4 & 0,7 & 0,2107 & 1,622 \\
$\mathrm{I}$ & 2,07 & 0,8 & 1,27 & 0,63 & 0,1917 & 1,555 \\
\hline
\end{tabular}

Sedimentação marinha:

$$
\begin{array}{lll}
\text { Esporão marinho } & -\mathrm{S}_{\mathrm{o}}: & \mathbf{1 , 5 5 5} \\
\text { Depósito praial } & -\mathrm{S}_{\mathrm{o}}: & 1,263 \text { e } 1,354
\end{array}
$$

Sedimentação intermediária:

$$
\begin{array}{lll}
\text { Bancos areno-argilosos } & -S_{o}: & 1,429 \text { e } 1,532 \\
\text { Mangrovitos } & -S_{o}: & 1,253 \text { e } 1,424
\end{array}
$$

Sedimentação terrígena:

$\begin{array}{lll}\text { Aluvião terrestre } & -\mathrm{S}_{\mathrm{o}}: & 1,662 \\ \text { Dunas eólicas } & -\mathrm{S}_{\mathrm{o}}: & 1,284\end{array}$

Deduzimos assim estatisticamente serem todos os sedimentos de litoral paranaense bem selecionados. Observa-se todavia, numa mesma formação, seleções diferentes, naturalmente denunciando modificações na deposição, variável de local a local, não afetando os resultados médios da região.

\section{AGRADECIMENTO}

Agradeço ao Dr. Marcos A. Enrietti, Diretor do Instituto de Biologia e Pesquisas Tecnológicas de Curitiba e ao Dr. Loureiro Fernandes, Diretor do Museu Paranaense, as facilidades que me concederam para viajar às regiões de interesse para este trabalho e ao Dr. R. Maack, chefe do Serviço de Geologia e Petrografia do I.B.P.T., a orientação científica que deu aos estudos efetuados.

Agradeço aos profs. Dr. K. E. Caster, Dr. Paulo Sawaya, Dr. F. K. Rawitscher e Dr. Ruy O. de Freitas, da Faculdade de Filosofia, Ciências e Letras da Universidade de São Paulo, a boa vontade com que me auxiliaram na confecção desta contribuição, fornecendo dados de real valor para sua conclusão.

\section{REFERÊNCIAS}

BACKHEUSER, E. (1918), A faixa litorânea do Brasil Meridional, ontem e hoje. Rio de Janeiro.

CARVAlHO, F. V. Miranda de (1930), Estudo de portos no Brasil (Ensaio). Rio de Janeiro.

FREYBERG, B. V. (1930), Zerstörung und sedimentation an der magrovenküste brasiliens. Leipzig.

JOHNSON, D. W. (1938), Shore processes and shoreline development. New York.

KRONE, R. (1908), Informações ethnographicas do vale do rio Ribeira de Iguape. Com. Geog. Geol. Est. de S. Paulo.

LAHEE, F. H. (1941), Field Geology. 4. ed. New York.

LAMEGO, A. R. (1940), Restingas na costa do Brasil. Bol. Div. Geo. Min., (96). Rio de Janeiro.

LEONARDOS, O. H. (1938), Sambaquis e concheiros naturais. Rio de Janeiro.Av. 18, D. N. P. M.

MAACK, R. (1937), Geografische und geologische Forschungen in Santa Catarina (Brasilien). Ergänzungsheft V zur Zeitschr. d. Ges. f. Erdkunde. Berlin. p. 1-85.

MAACK, R. (1946), Geologia e Geografia da região de Vila Velha, Estado do Paraná e considerações sobre a glaciação carbonífera no Brasil. Arquivos do Museu Paranaense, Curitiba, 5.

MARTYN, B. A. (1934), A note on the foreshore vegetation in the neighbourhood of Georgetown, British Guiana, with special reference to Spartina brasiliensis. The journal of Ecology, Cambridge, 22 : 292-298.

MORTENSEN, T.; LIEBERKIND, I. (1928), Echinoderma; em Grimpe,G. Die tierwelt d. Nord u. Ostsee. fasc. 12, pt. 8. Leipzig. 128 p.

OLIVEIRA, A. I.; LEONARDOS, O. H. (1943), Geologia do Brsil. 2. ed. Rio de Janeiro.

PERRIER, E. (1875), Recherches sur l'Appareil Circulatoire des Oursins. Arch. Zool. Gén. et Exper., Paris, 1-4 (23-24) : 605-643.

RAWITSCHER, F. K. (1944), Algumas noções sobre a vegetação do litoral brasileiro. Bol. Ass. Geog. Bras., 5 : 13-28.

RIOJA LO BIANCO (19--), Los equinodermos in "Historia Natural - vida de los animales de las plantas y de la Tierra". Zoología (invertebrados). (2) : 393-408.

SAMPAIO, A. J. (19--), Nomes vulgares de plantas do Distrito Federal e do Estado do Rio de Janeiro. Bol. Mus. Nac., (4). Nova Série Botânica.

STELLFIED, C. (1945), Estudo da flora marítima do Paraná. Arq. Mus. Paranaense, 4.

TWENHOFEL, W. H. (1939), Principles of sedimentation. New York.

VON UEXKÜLL, J. (1897), Ubre die Funktion der polischen blasen am kauapparat der regulären seeigel. Mitt. Zool. Station Neapel, Berlin, 12 (21) : 463-476. 
WINTERSTEIN, H. (1921), Die physikalischchemischen Erscheinungen der Atmung em Winterstein, H. Hand. d. Vergl. Physiologie, Jena, 1 ( $2^{\circ}$ metade) : 1-264. 


\section{FIGURAS}

\section{1 a 58}




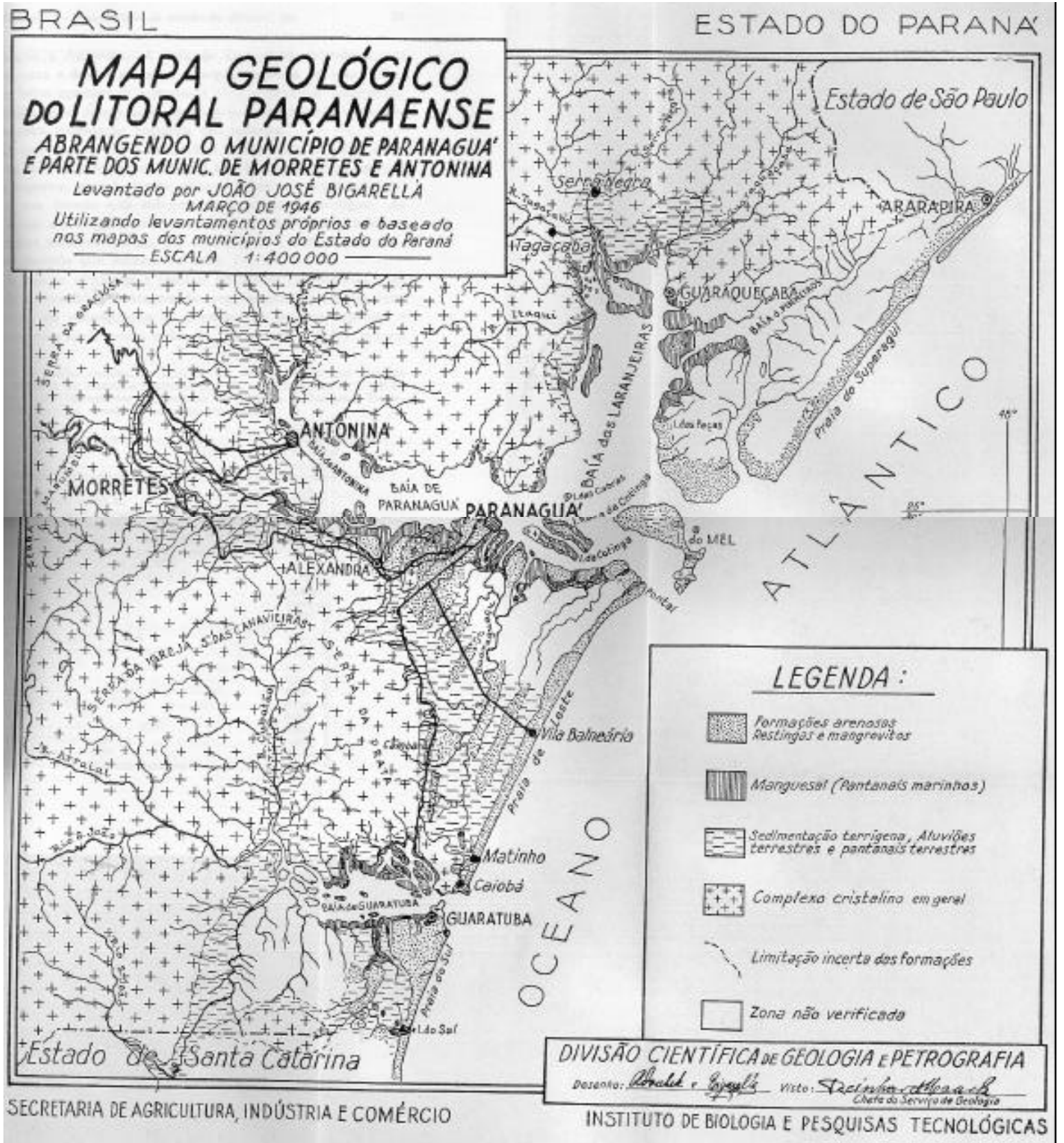

Fig. 1 - Mapa geológico do litoral paranaense 


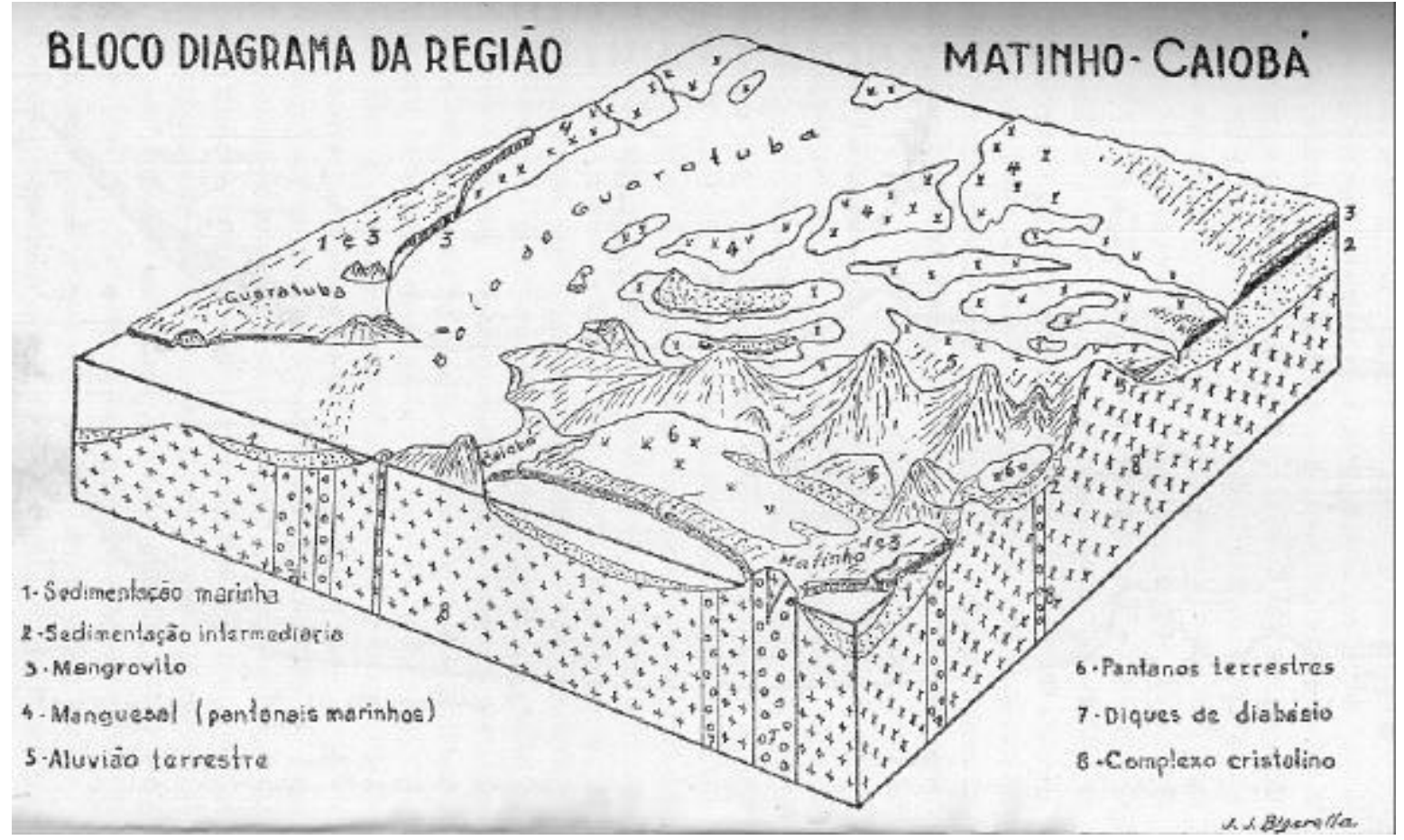

Fig. 2 - Bloco diagrama da Região Matinhos-Caiobá

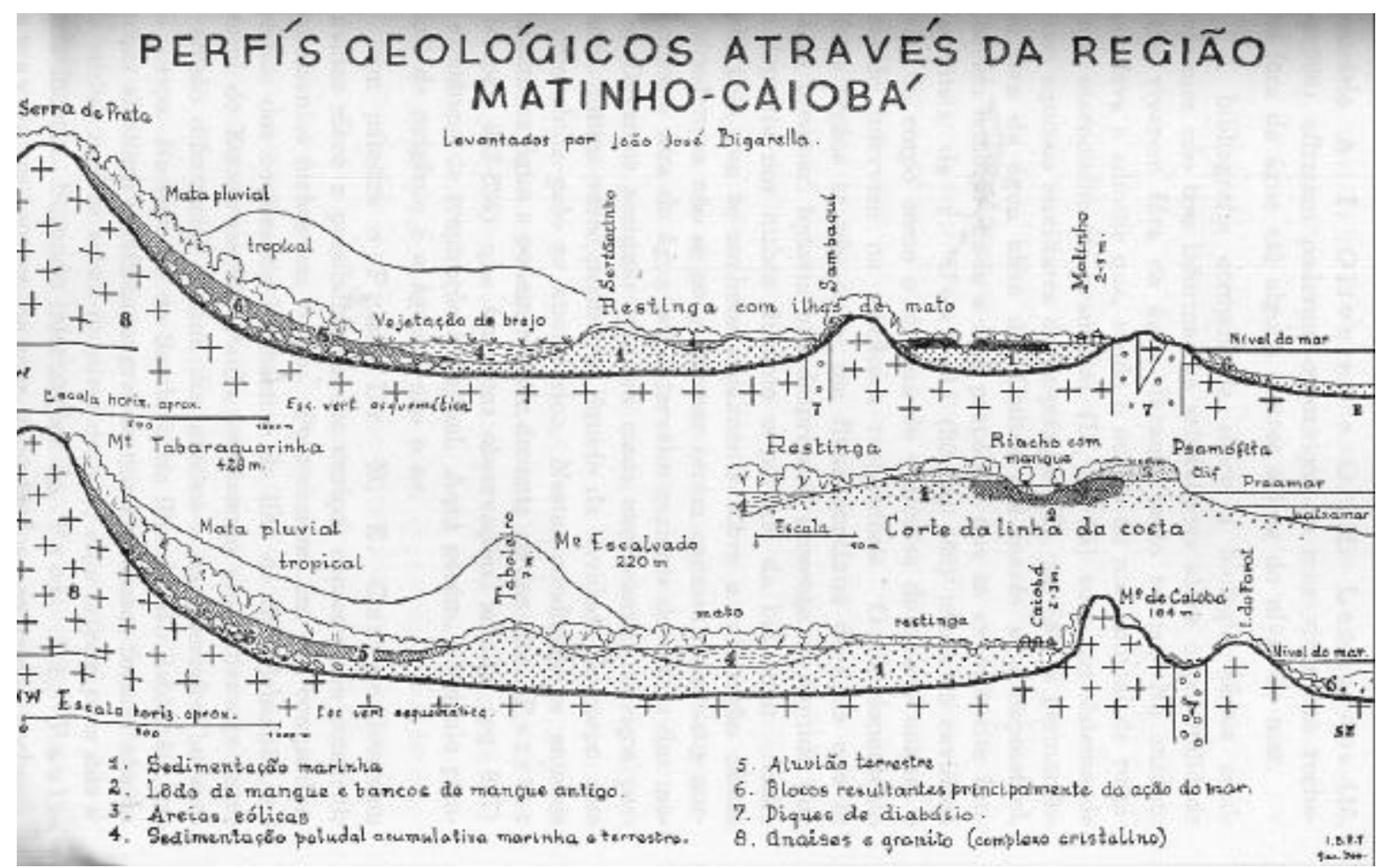

fig. 3 - Perfis geológicos através da Região Matinhos-Caiobá 


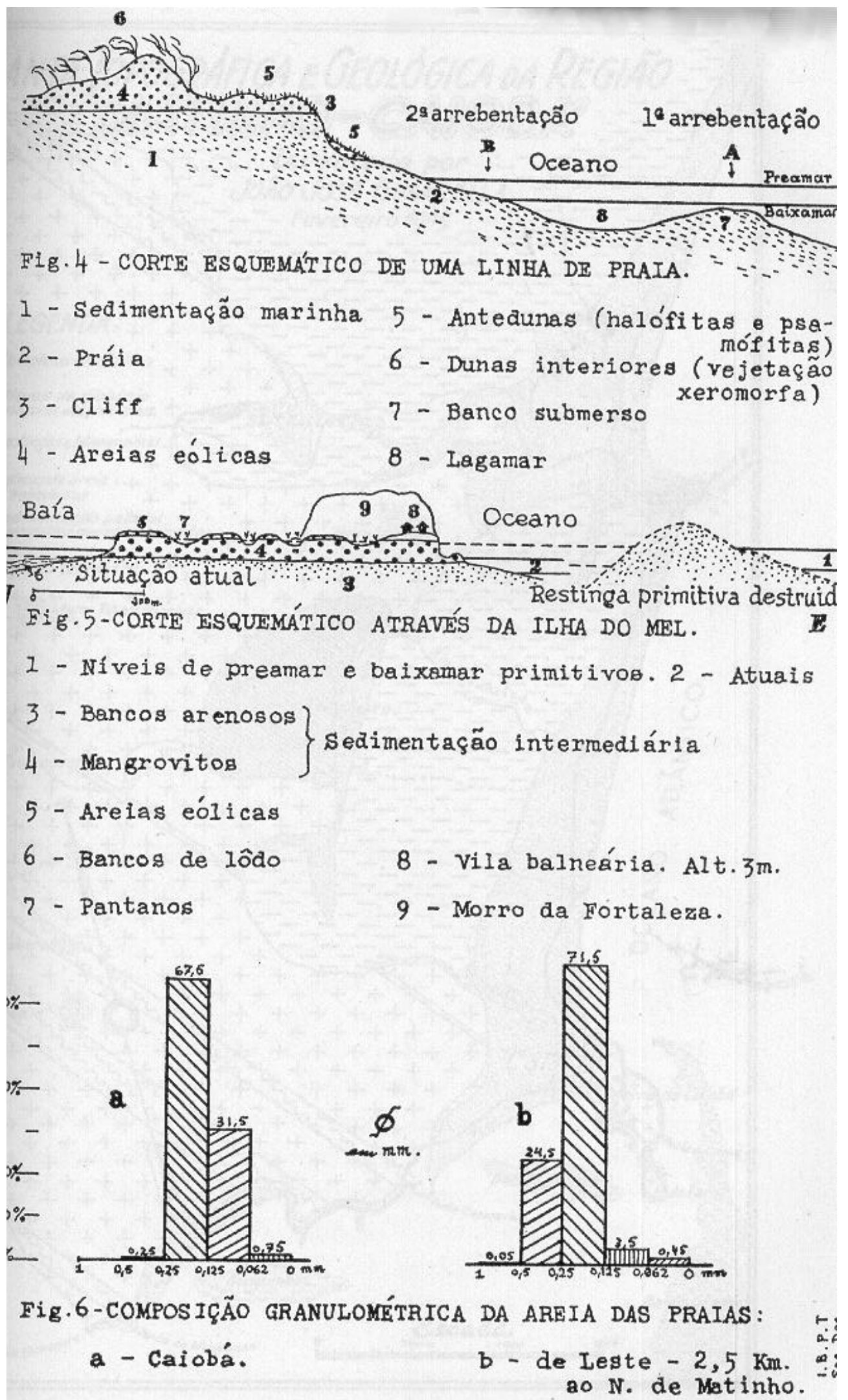

fig. 4,5 e 6 


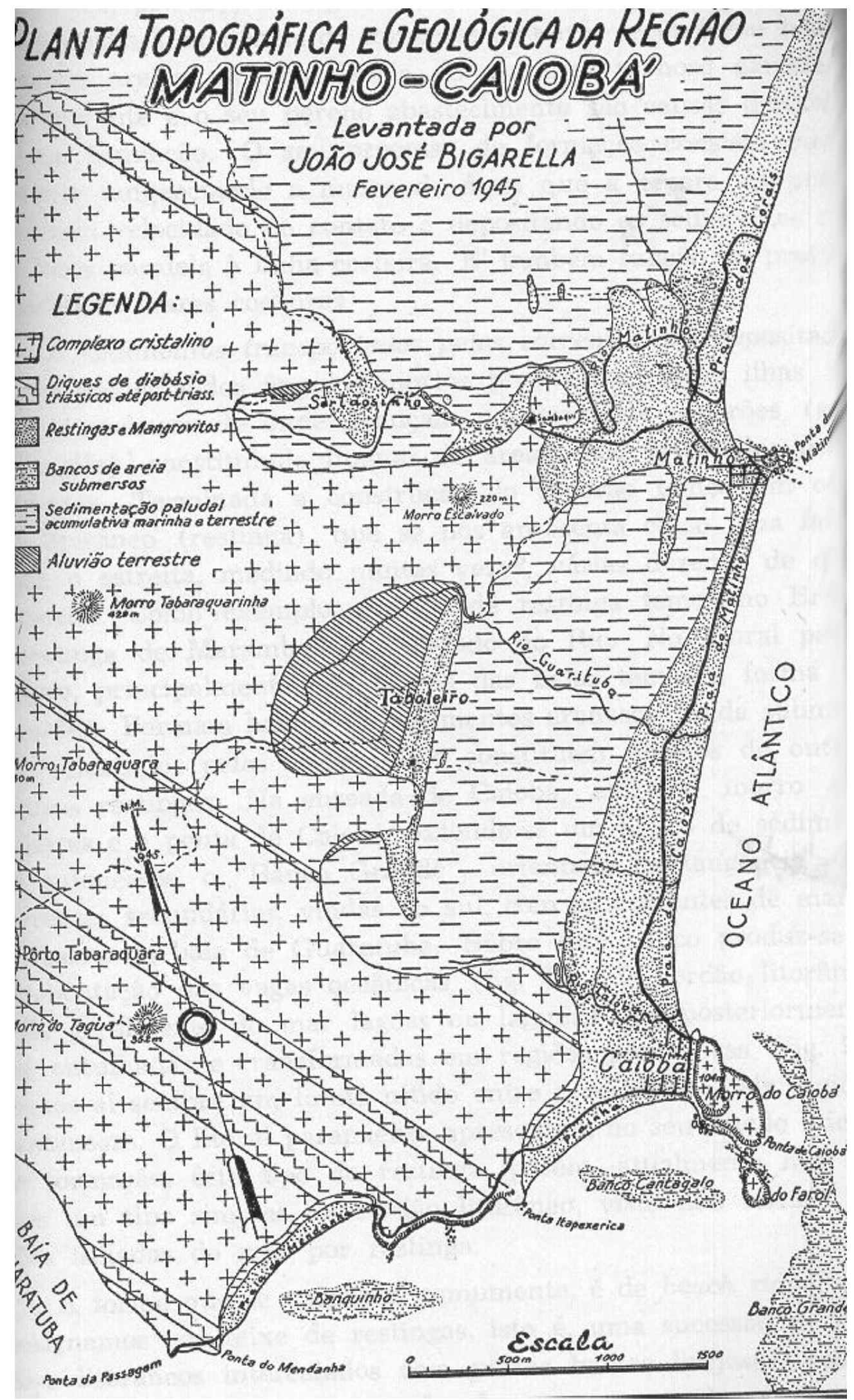

fig. 7 - Planta topográfica e geológica da Região Matinhos- Caiobá 


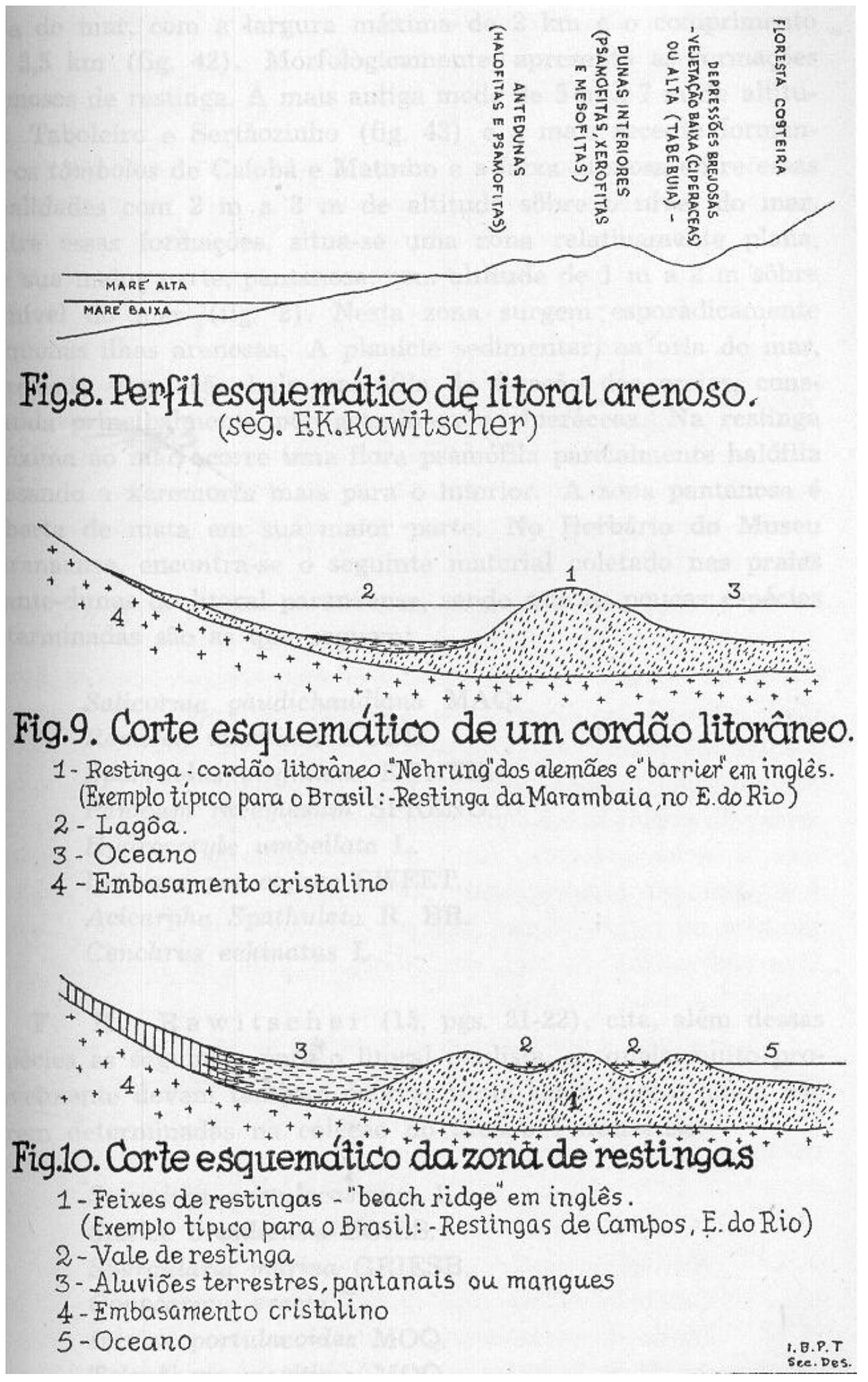

fig. 8,9 e 10 


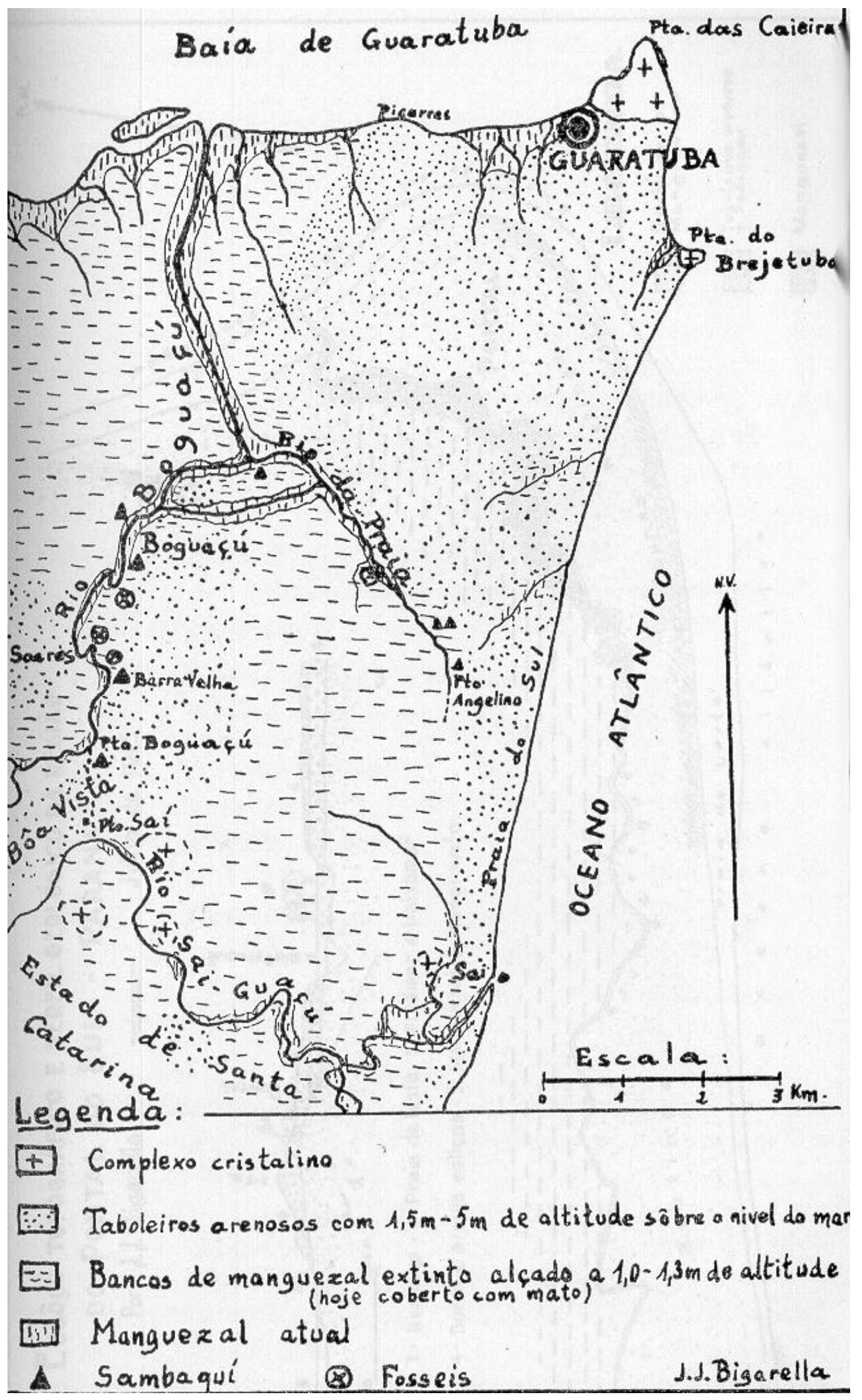

fig. 11 - Levantamento topográfico-geológico da zona da praia Sul. 


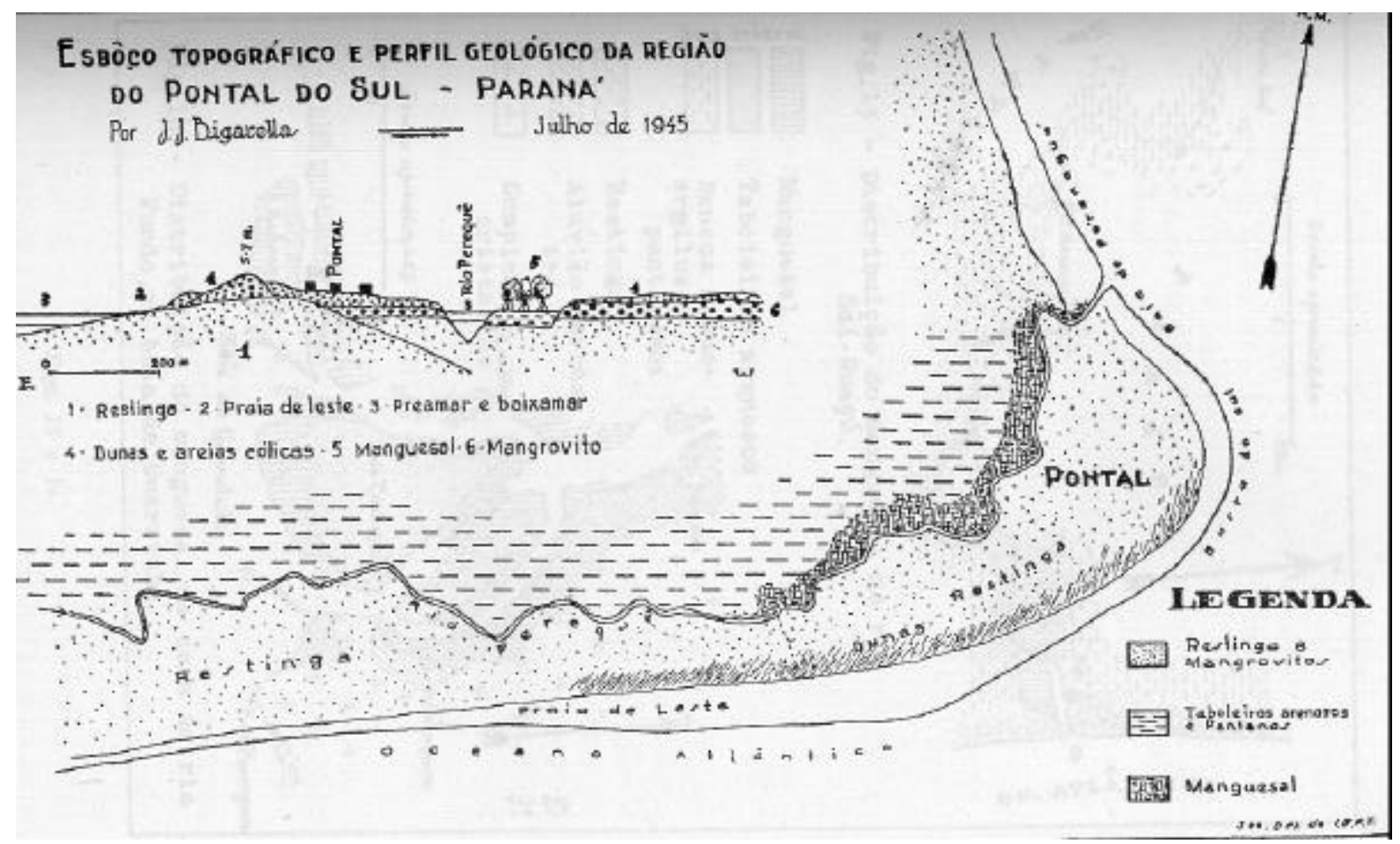

Fig. 12 - Esboço topográfico e perfil geológico da Região do Pontal do Sul - Paraná (Esc. aprox. 1 : 50.000) 


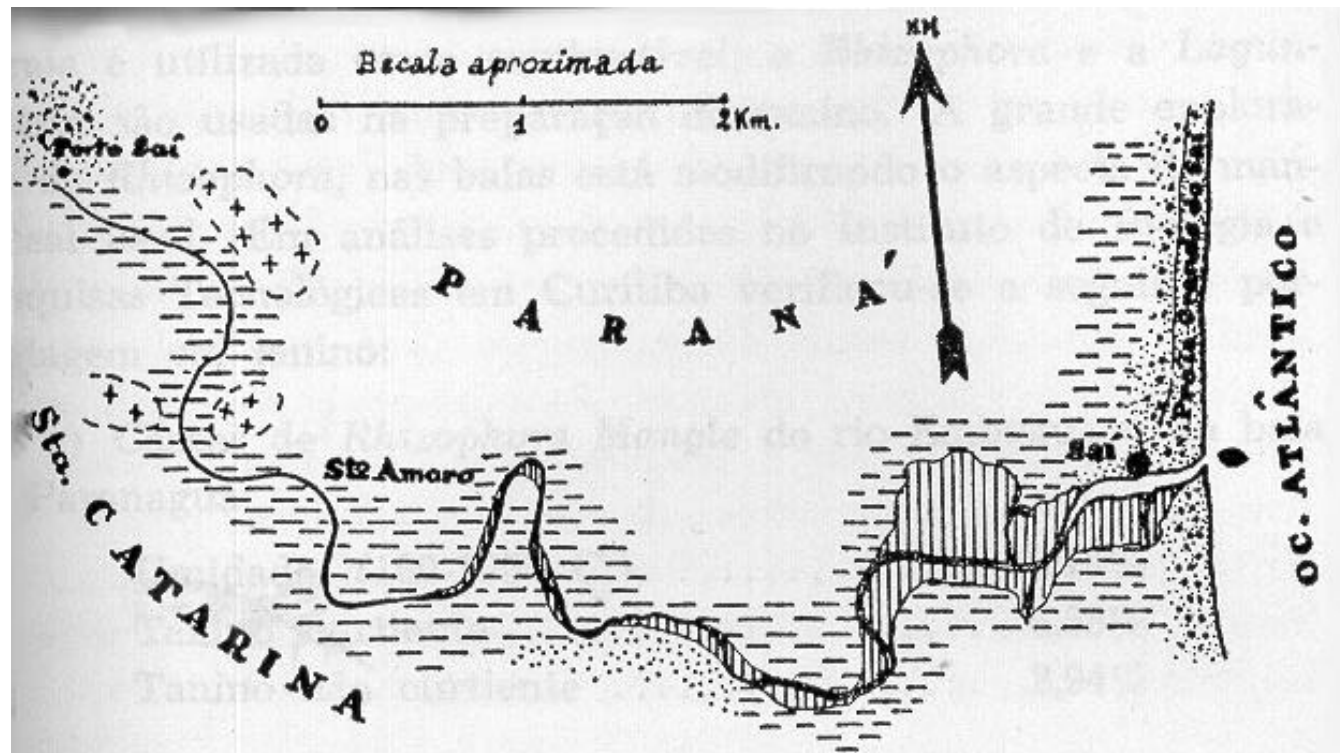

F1g.13 - Distribuịção do manguesal no rio
Saí-Guaçú.

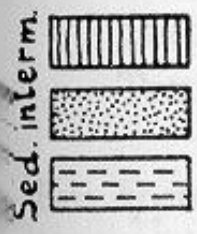

Manguese1

Taboleiros arenosos

Bancos arenoargilosos pantanosos
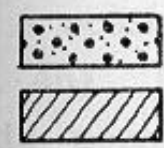

festinga

Aluvião terrestre.

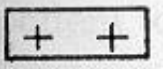

Complexo
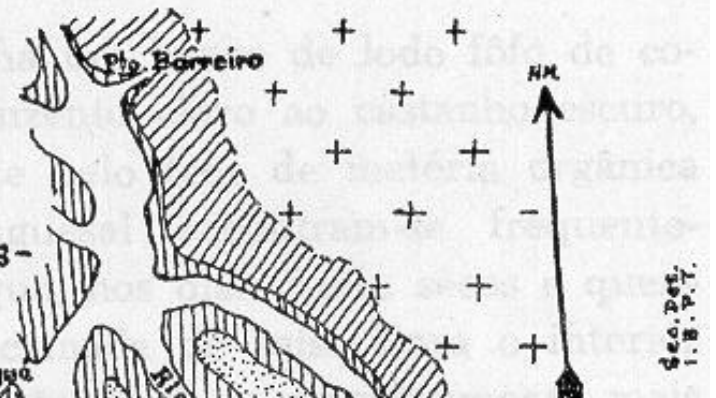

$\frac{\text { Escala aproximada }}{1}$. $\mathrm{km}$

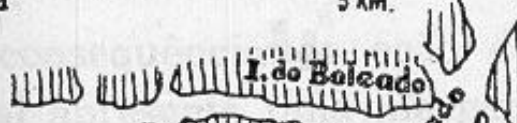

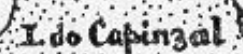

I do Capinzal

IT das Nasa

iivilifind

Sraía do Guaratuba

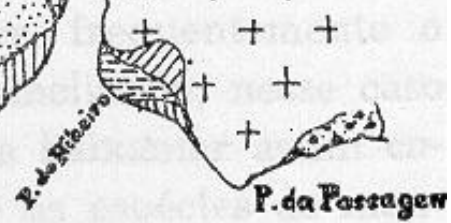

P1g.14 - Distribuif̧ăo do manguesal na zona do rio

Fundo, na bafa de Guaratubs.

Fig. 13 e 14 


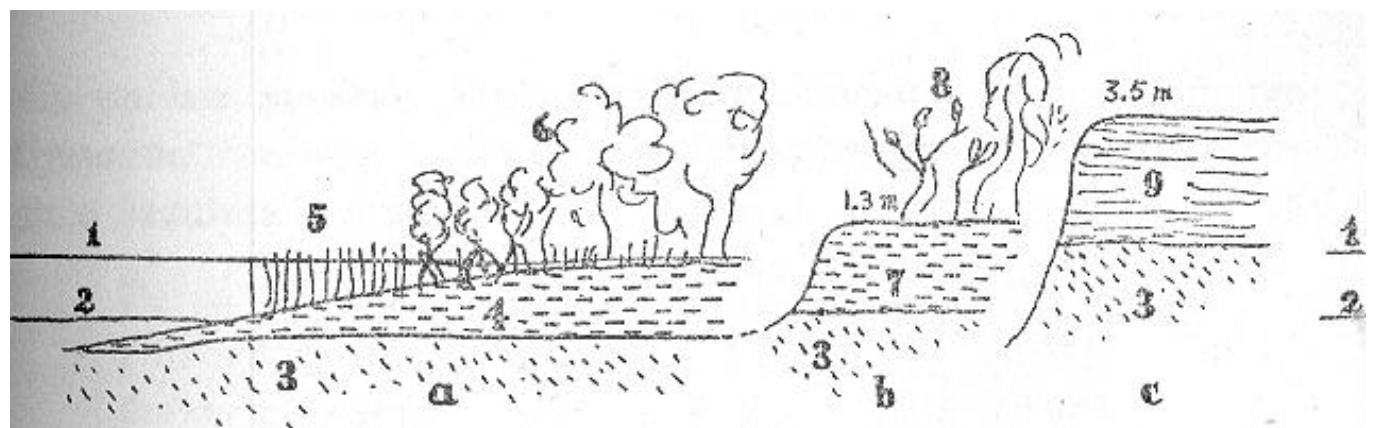

Fig. 15 - ESBÔCO COMPARATIVO DOS DIFERENTES ESTÁGIOS DOS BAKCOS DE MAMGUBSAL OBSERTADOS NO LITORAL PARANAENST.

a. - Estágio atual.
1. nível da preamar
2. nível da baixtarnar.
3. areies claras
4. 10 do
5.praturá (s.brasiliensis)

b - Bencos de marguesal recentemente exintos.

7. sedinentos escuros de manguesal antigo

8.Hibiscus tiliaceus $\theta$ mata

c - Bancos do manguesal antigo (mangrovito)

9.arejas castanho escuras compactas

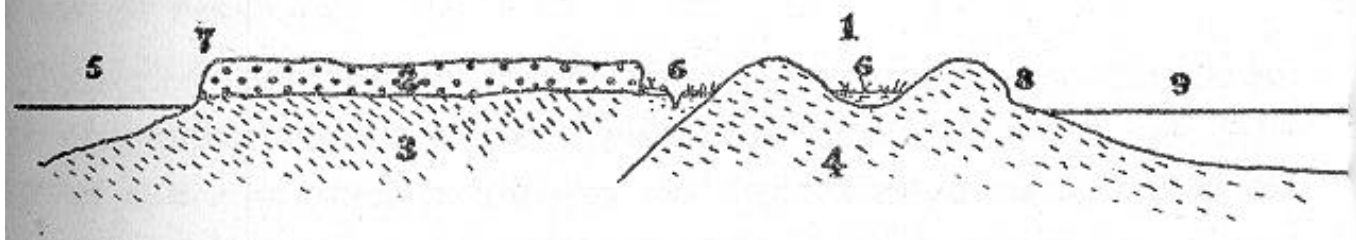

Fig. 16 - ESBOCOO DRMONSTRANDO O COHTRASTR ENTRE AS FRGTINGAS E O MARTROVITO.

1. Feixe de reotingas

2. Mangrovito

5. Baía de Guaratuba

3. Aredas amareio-claras do. sedimentação intermediária

4. Areias marinhas

6. Brejos

7. Plçarras, 3.5 m. altit.

8. Praja Grande do Saí

9. Oceano

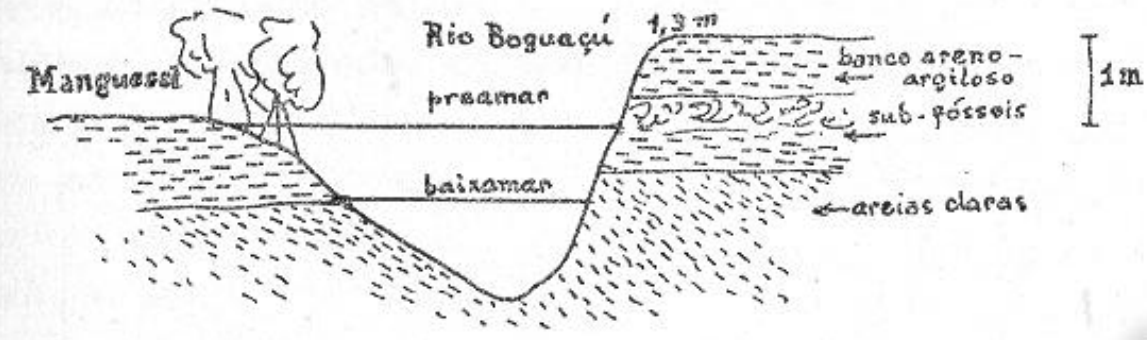

Big. 27 - BArCO FOSSILÍ́gro DO RIO BOGUACÚ (GUARATUBA).

Fig. 15,16 e 17 


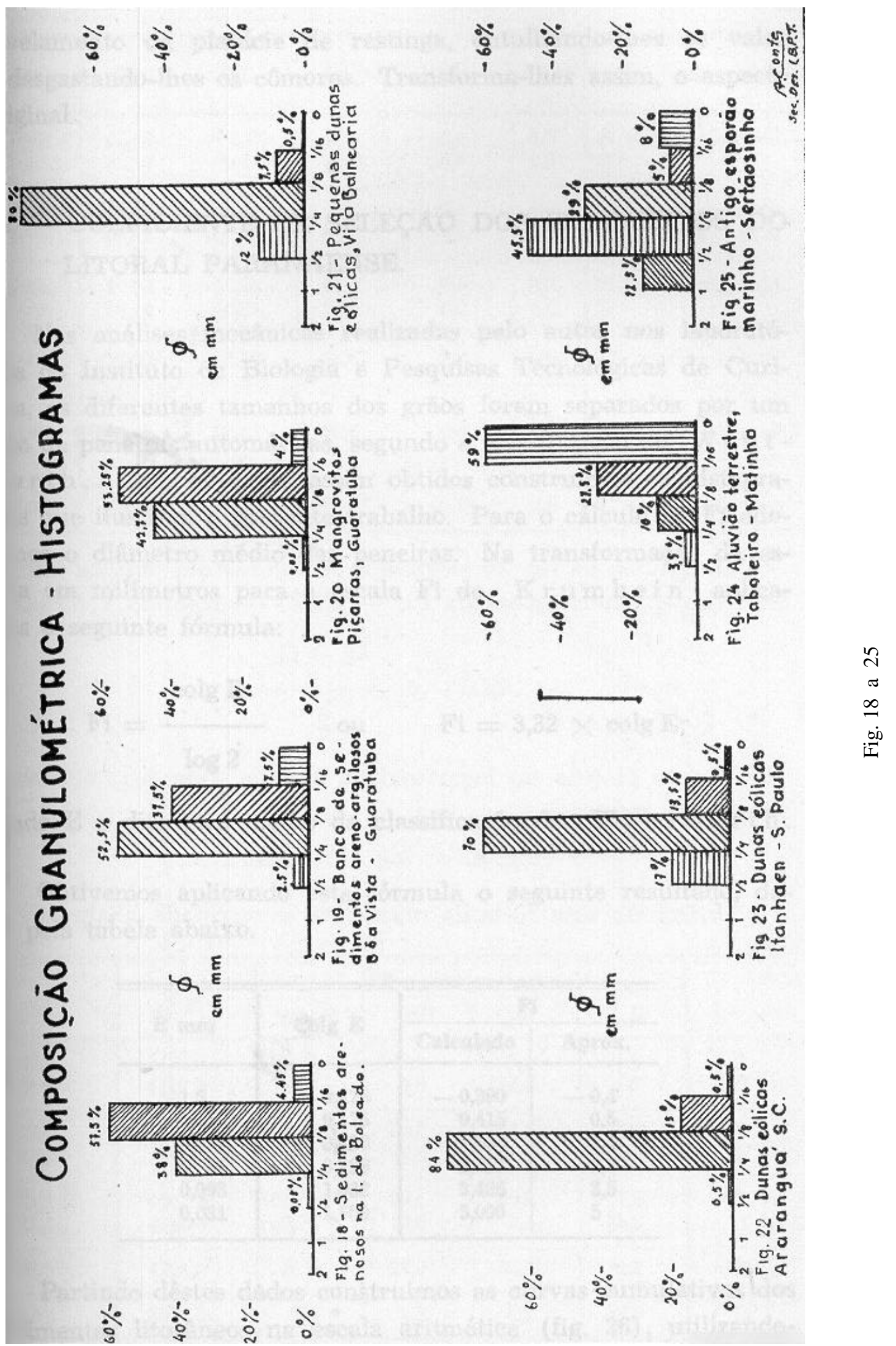


Bigarella, J. J.

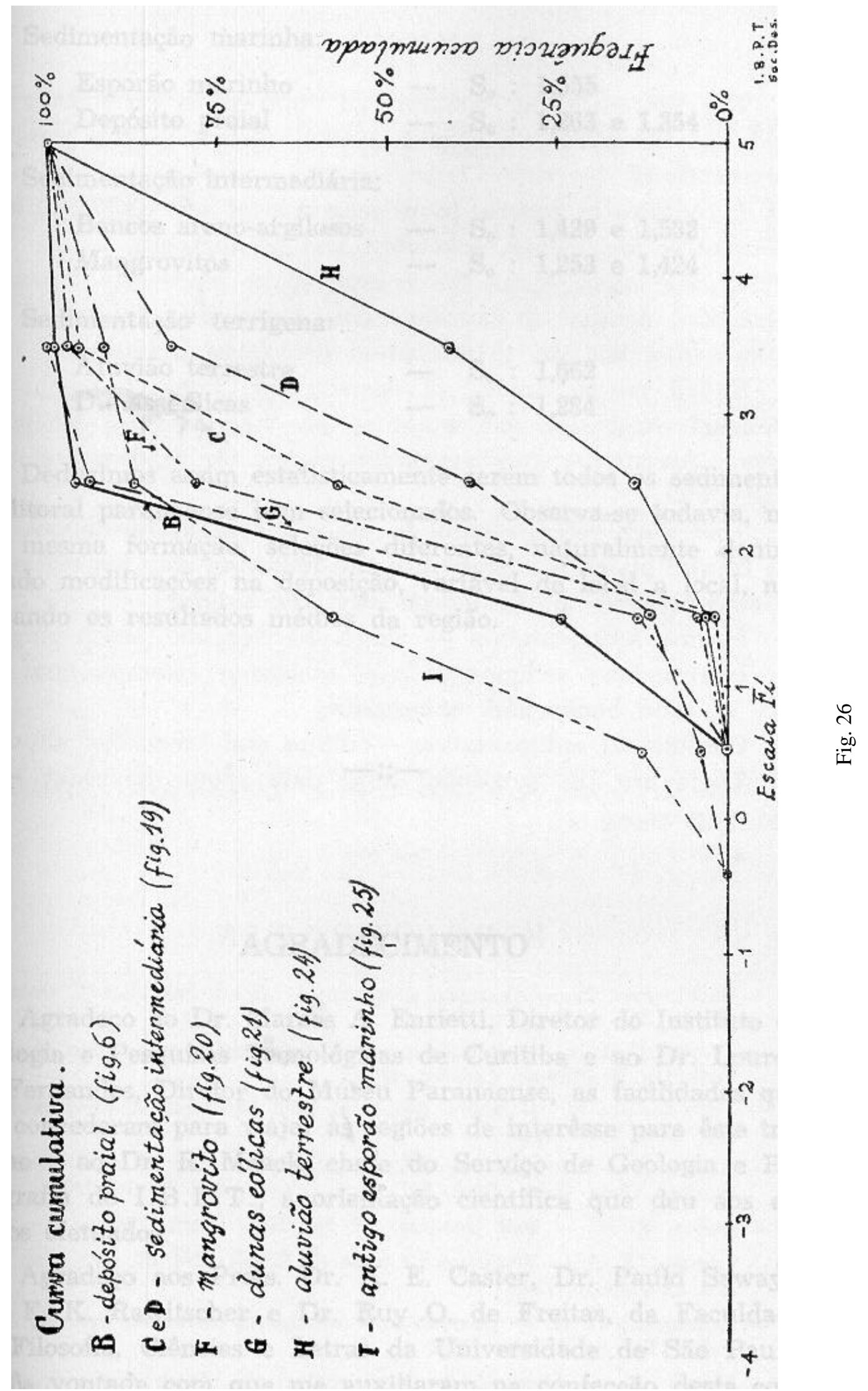

Brazilian Archives of Biology and Technology 


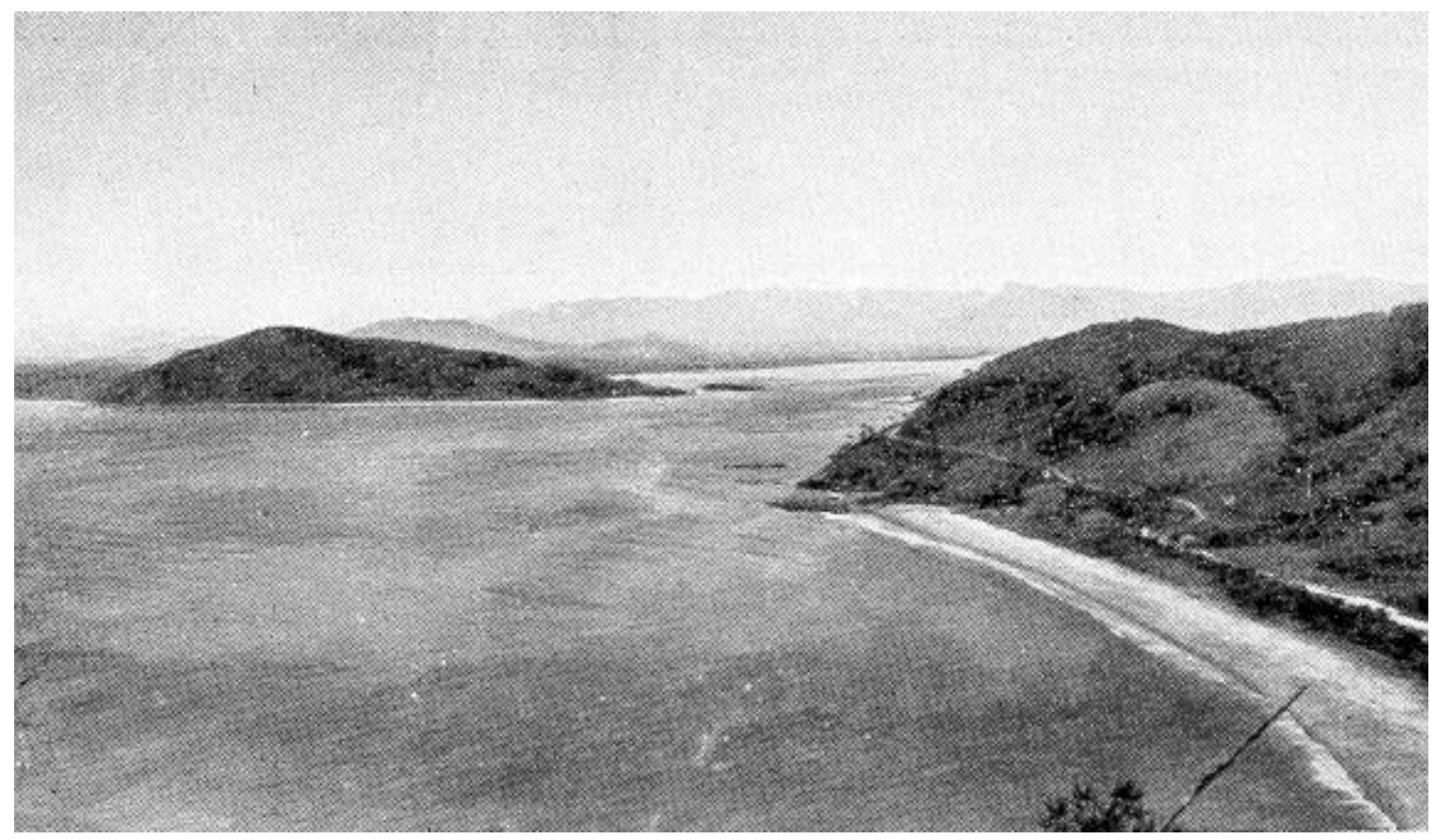

Fig. 27 - Vista tomada do morro de Caiobá em direção SW. Sobre a enseada de Caiobá e baia de Guaratuba. À esquerda, o morro das Caieiras, à direita, a serra da Prata mergulhando no oceano. Ao fundo, a Serra do Mar.

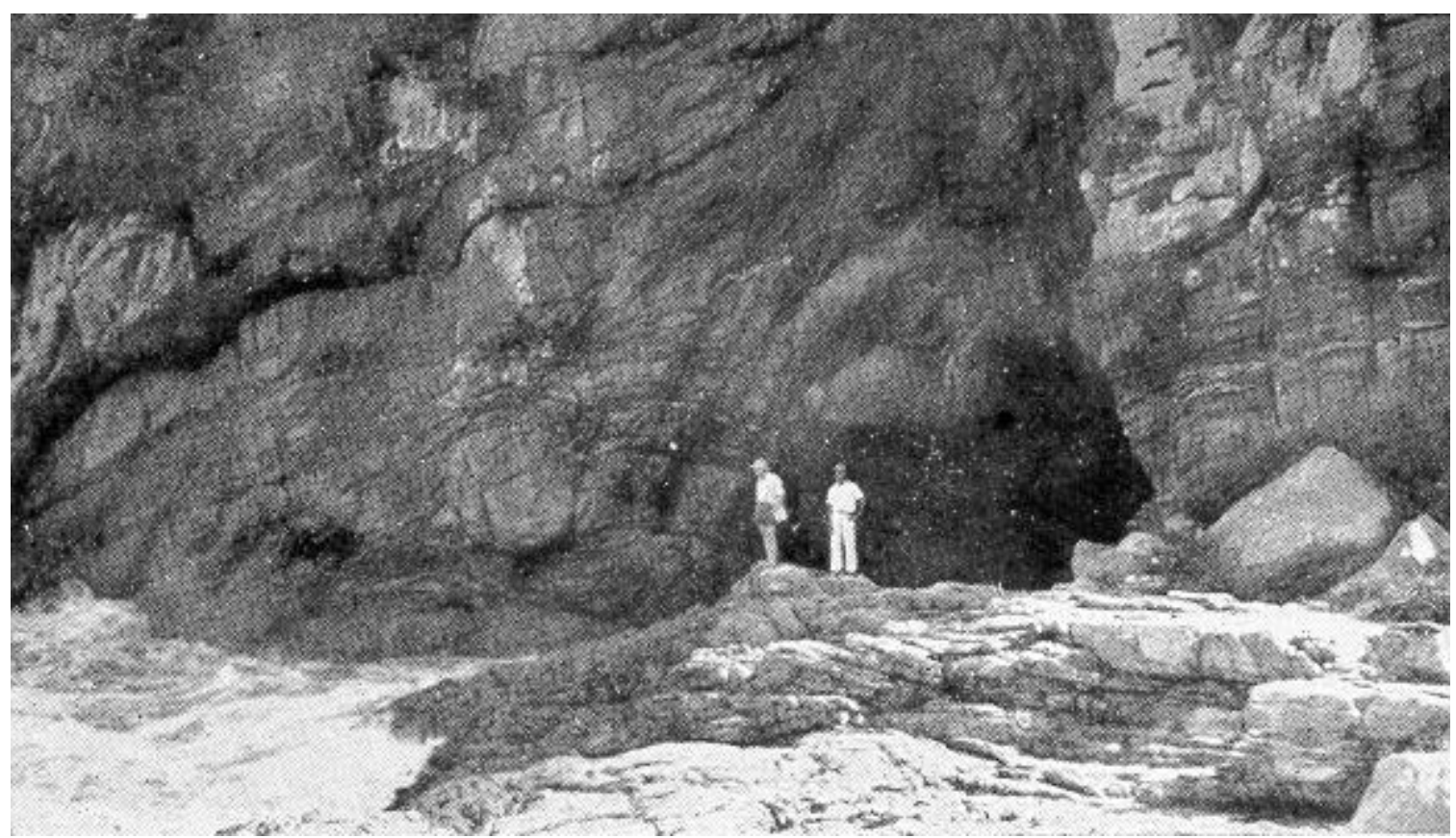

Fig. 28 - Gruta de vaga, aberta pela ação marinha em gnais atravessado por um pequeno dique de diabásio. Encantadas, Ilha do Mel. 


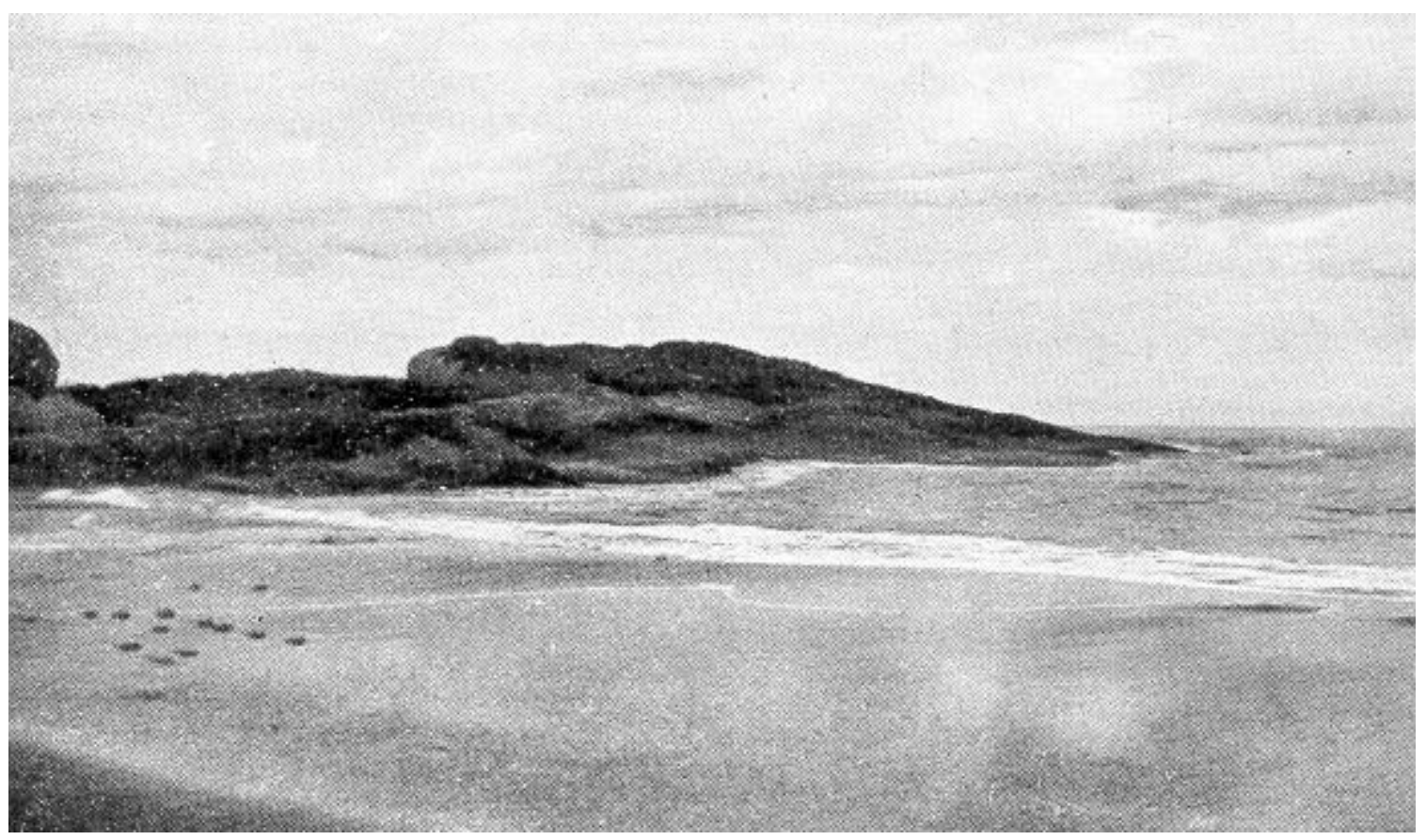

Fig. 29 - Sinais de ação marinha a $7 \mathrm{~m}$ de altitude nas rochas do Brejetuba. Na frente, à esquerda, um grupo de medusas, atiradas à praia pelas ondas.

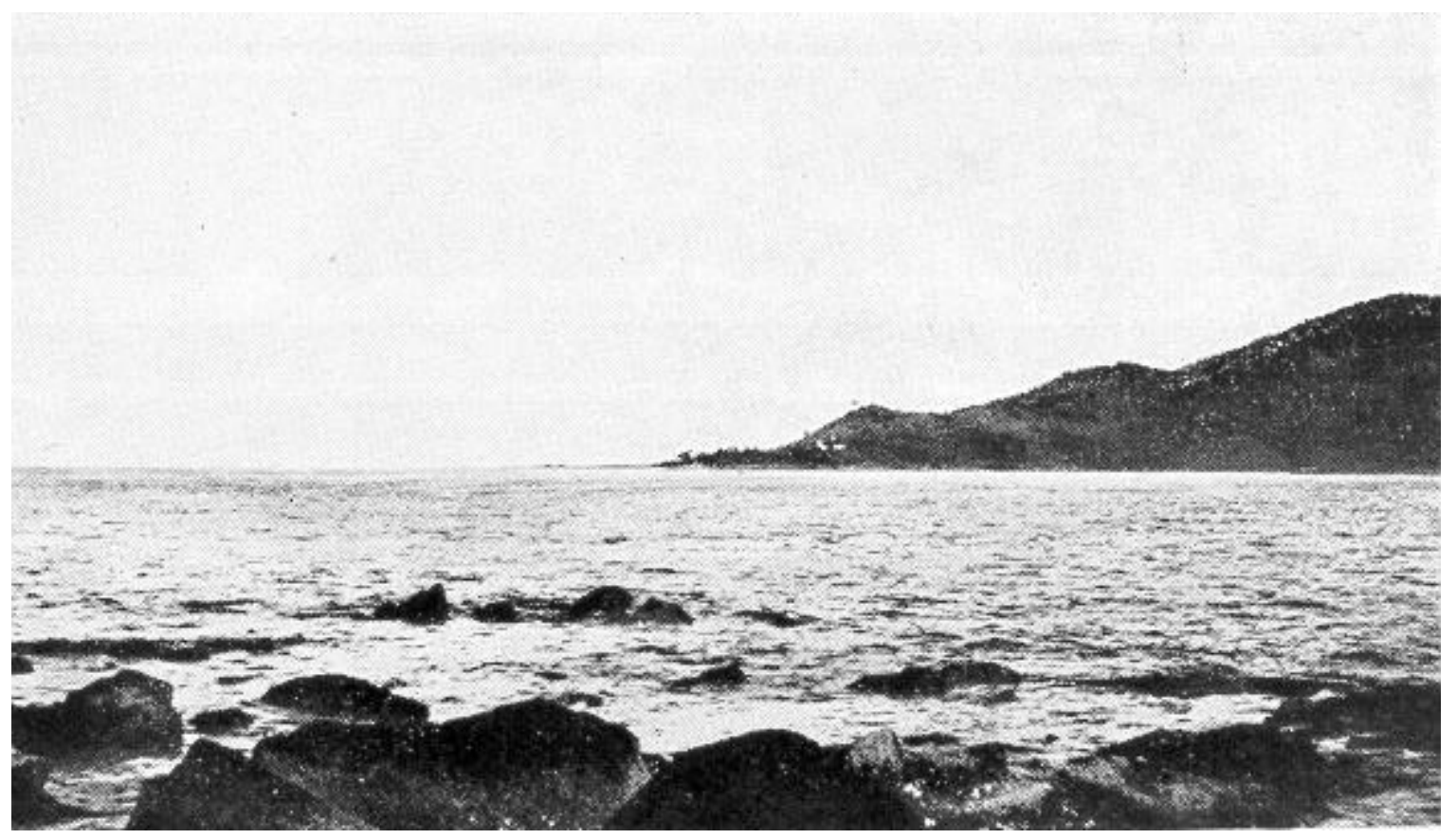

Fig. 30 - Sinais de ação marinha (terraço) na ponta das Caieiras, a cerca de $30 \mathrm{~m}$ de altitude. Vista tomada da ilha da Pescaria, na baia de Guaratuba. 


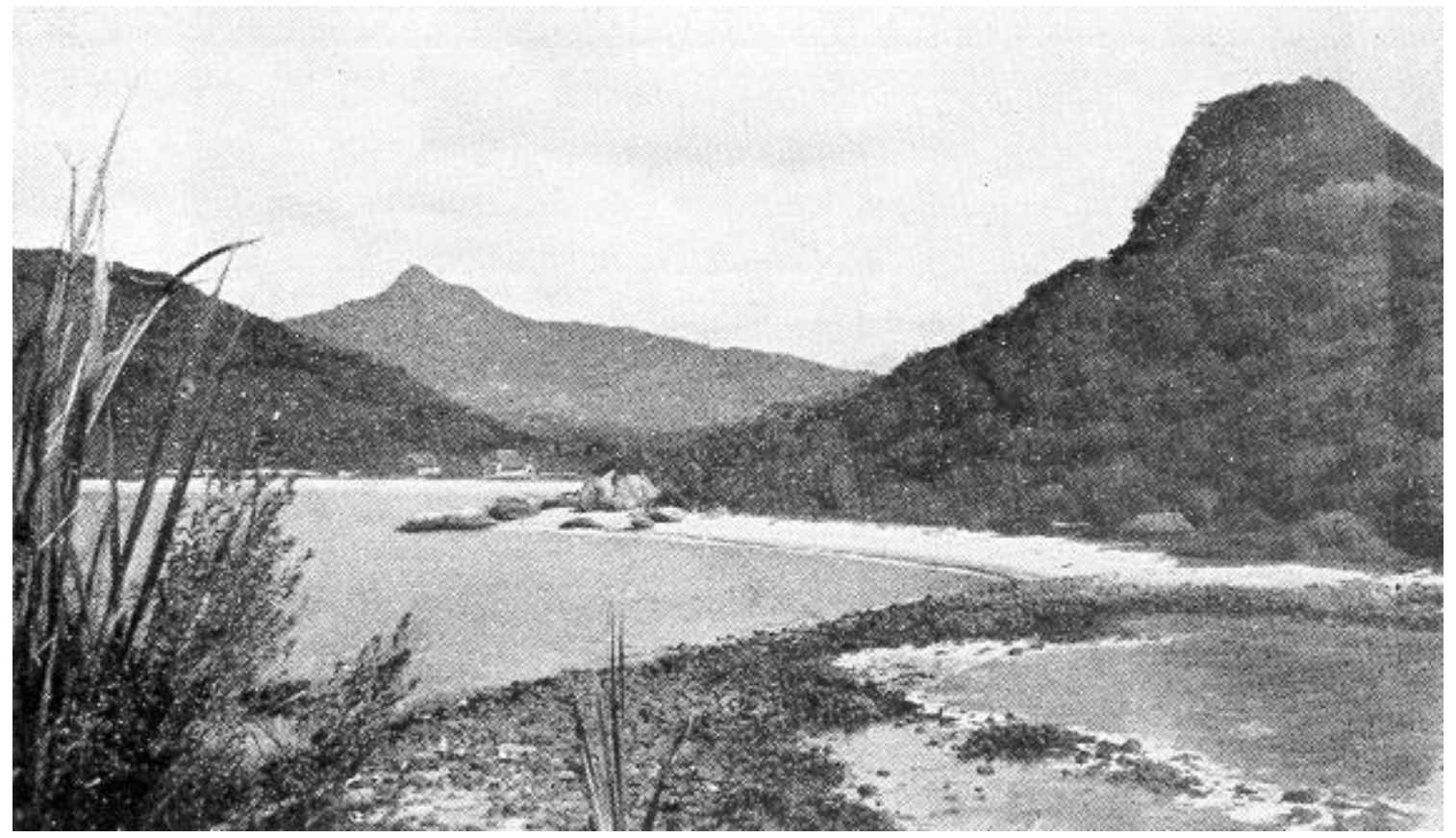

Fig. 31 - Vista tomada da ilha do Farol, em direção NW. Ao fundo, o morro Tabaraquarinha, $428 \mathrm{~m}$ de altitude, à direita o morro de Caiobá, $104 \mathrm{~m}$. No istmo de blocos, nota-se a presença de um dique de diabásio com a direção $\mathrm{N}$ $320^{\circ}$ E magn. Adiante, matacões e trecho da Prainha.

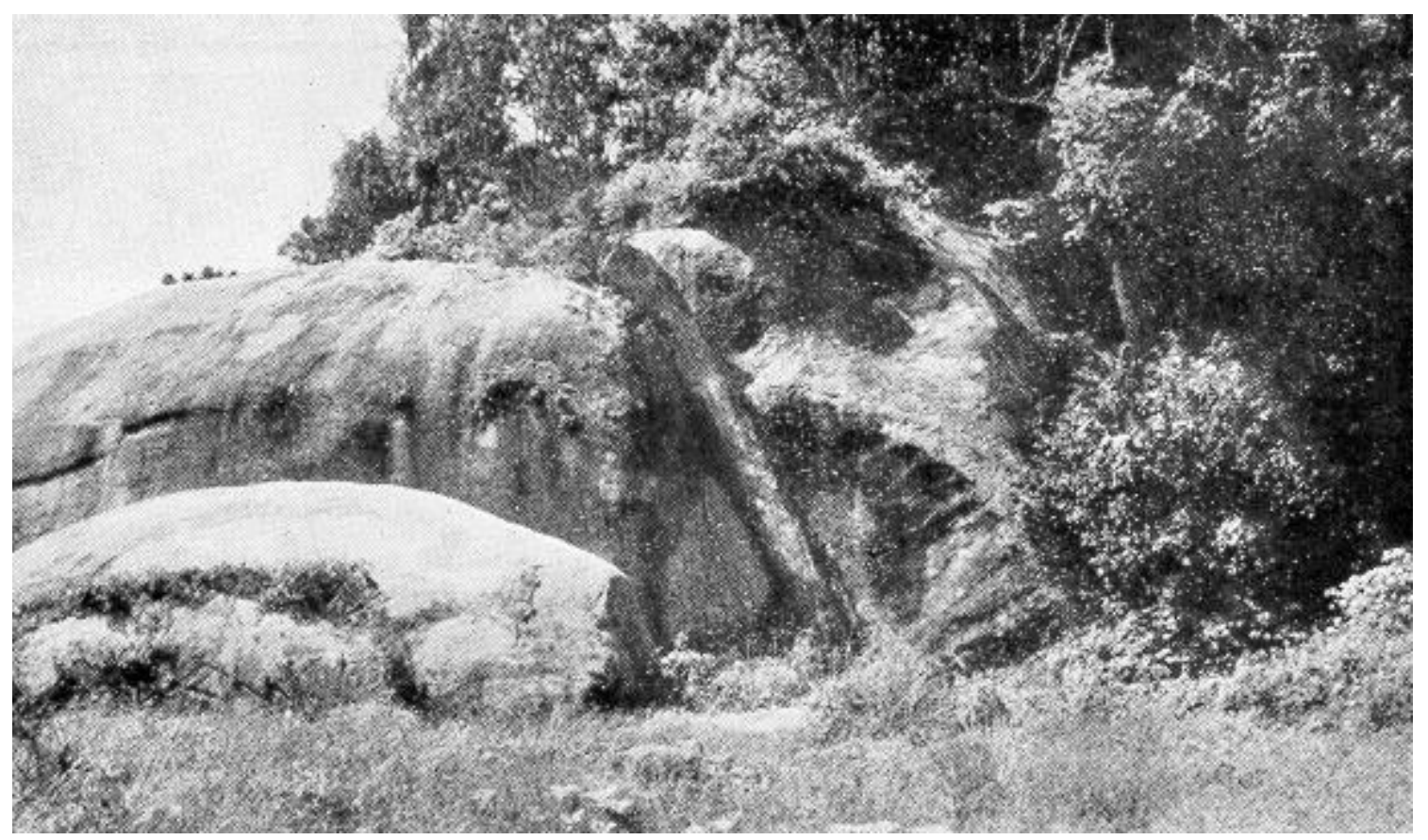

Fig. 32 - Bloco rompido pelo contraste de temperatura - rompimento de núcleo. Encostas do morro de Caiobá. 


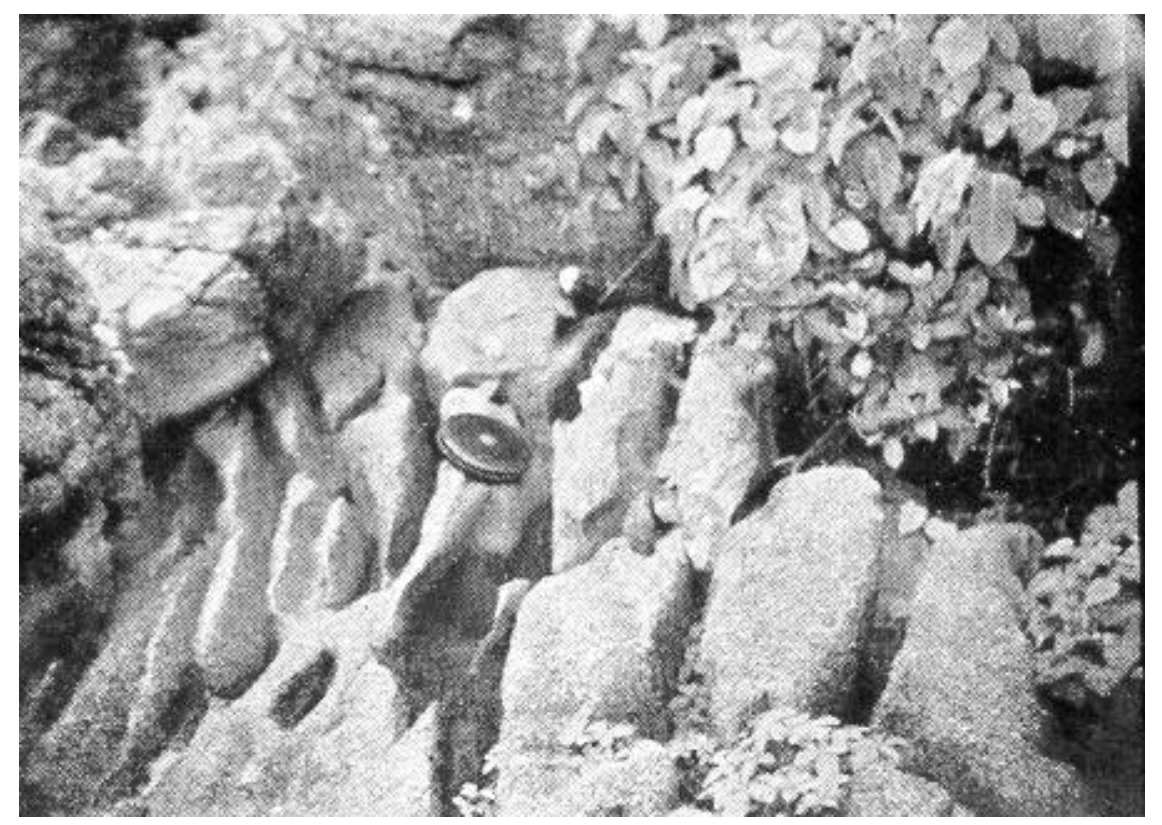

Fig. 33 - Erosão diferencial nas rochas da ilha do Farol, Caiobá.

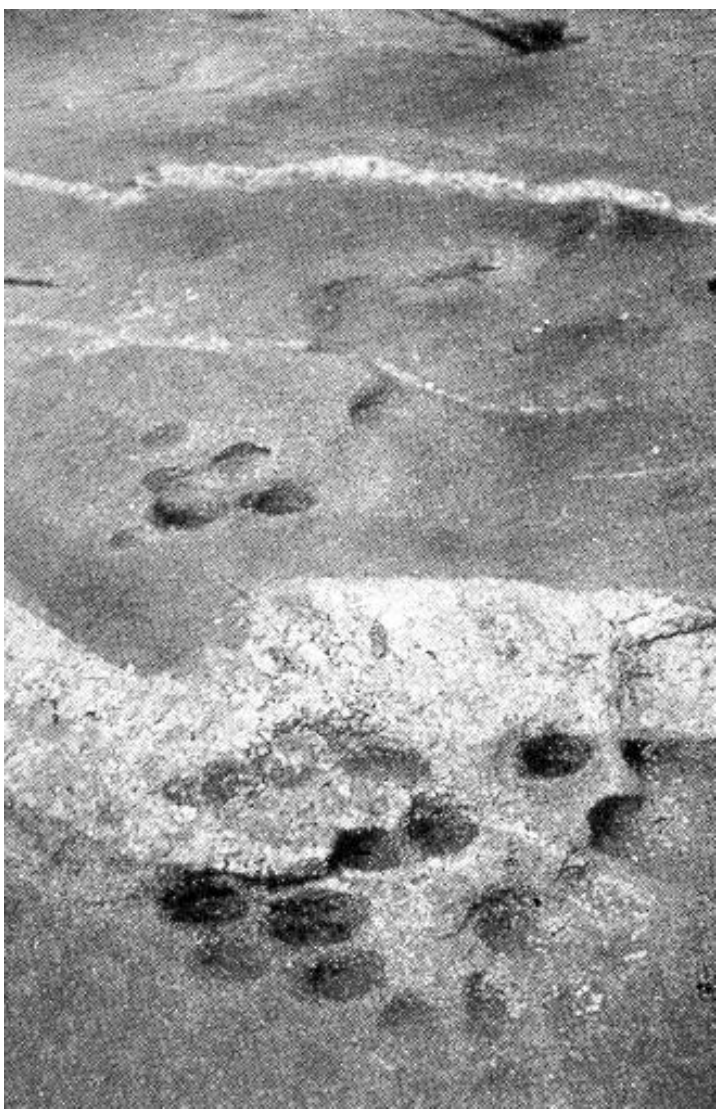

Fig. 34 - Outra forma de erosão. Estas formas arredondadas, são tidas na literatura geológica como buraco de ouriço. Estes buracos acham-se fora do alcance das marés. Tem no seu interior restos de Balanus. 


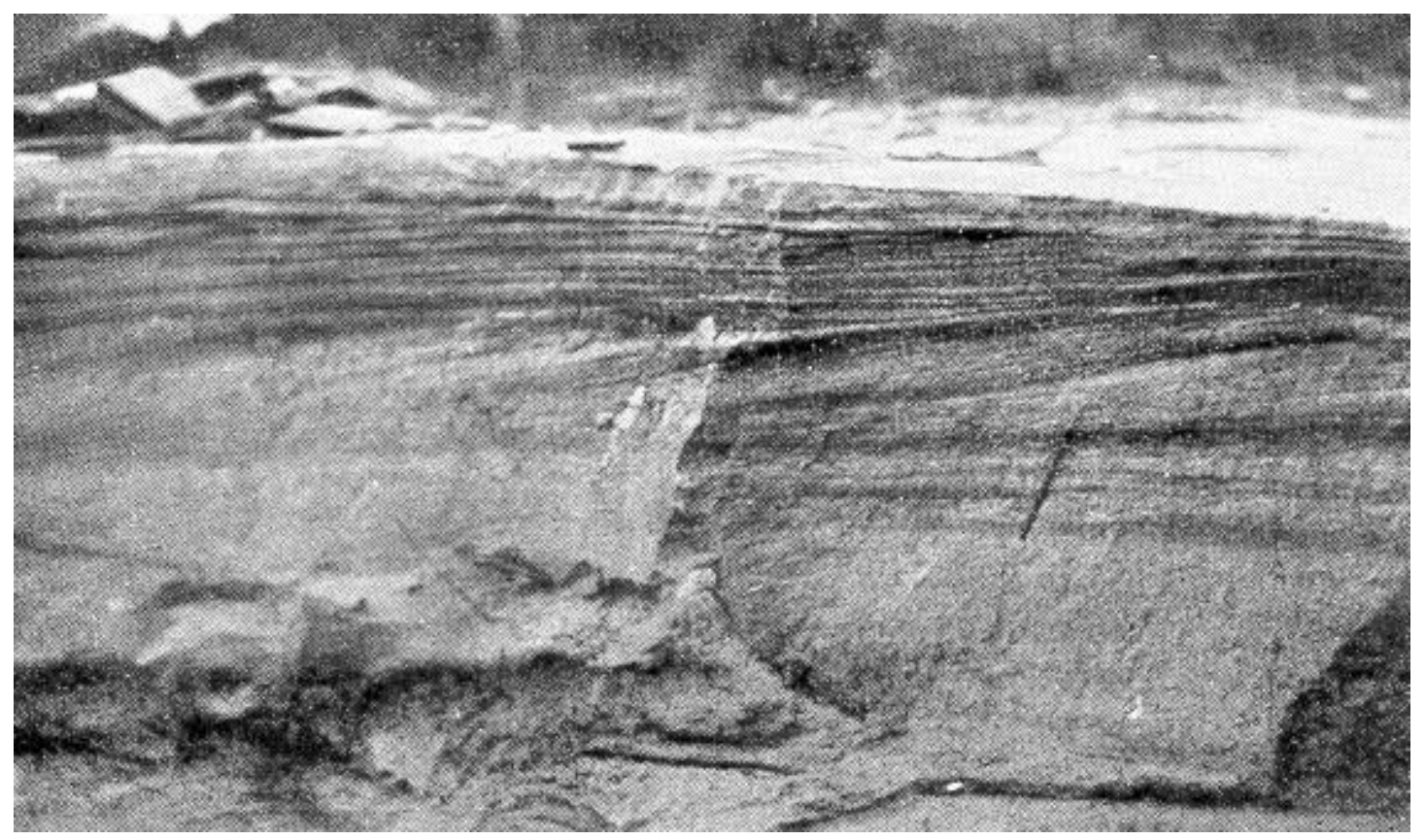

Fig. 35 - Depósito praial - estratificação paralela discordante. As linhas escuras são constituídas em sua maior parte por grãos de ilmenita, nas claras domina o quartzo. Ilha do Mel.

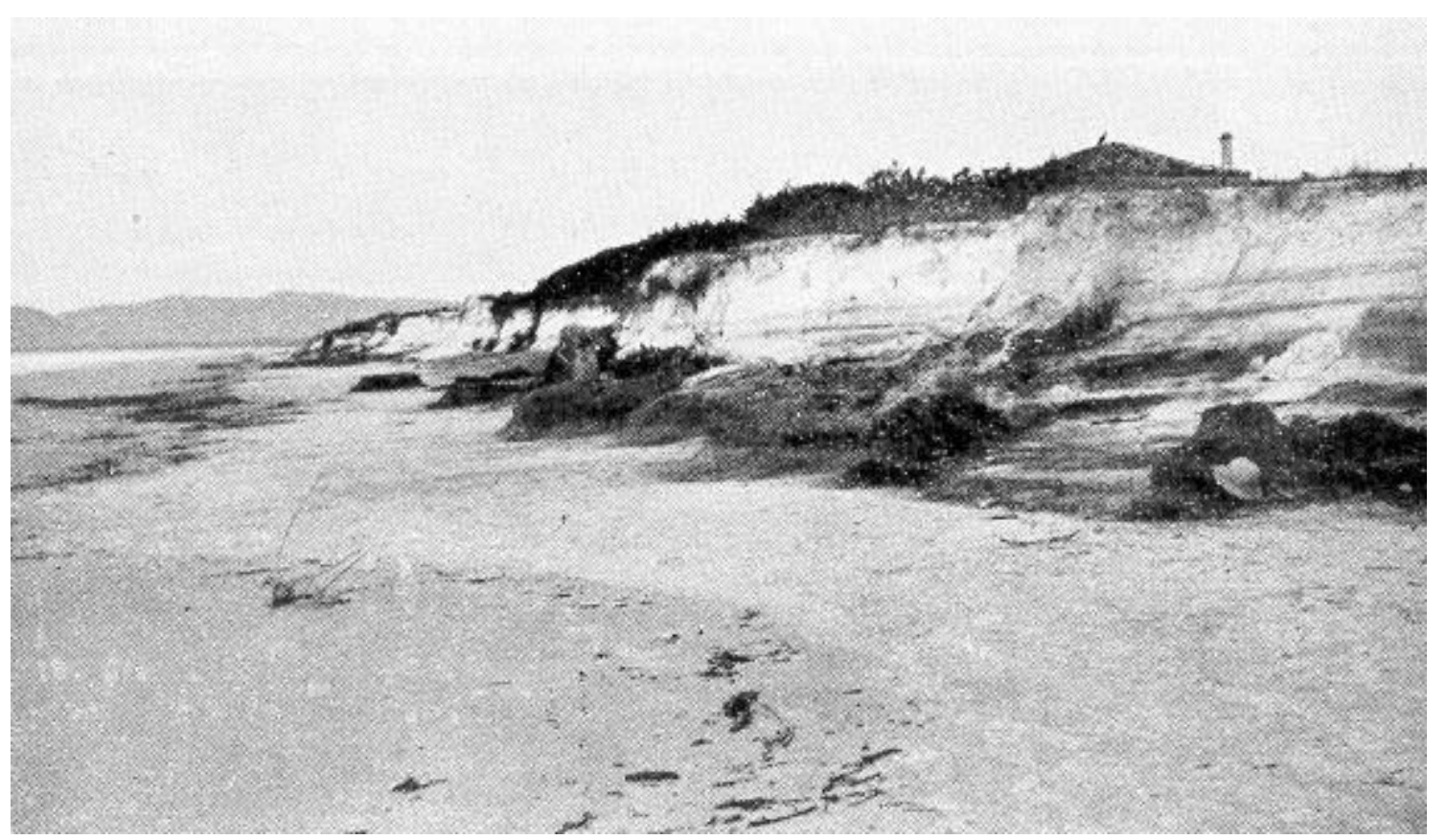

Fig. 36 - Cliff aberto em sedimentos escuros de manguezal antigo (mangrovito), atestando um avanço do mar na região da Ilha do Mel. Praia da ilha do Mel. 


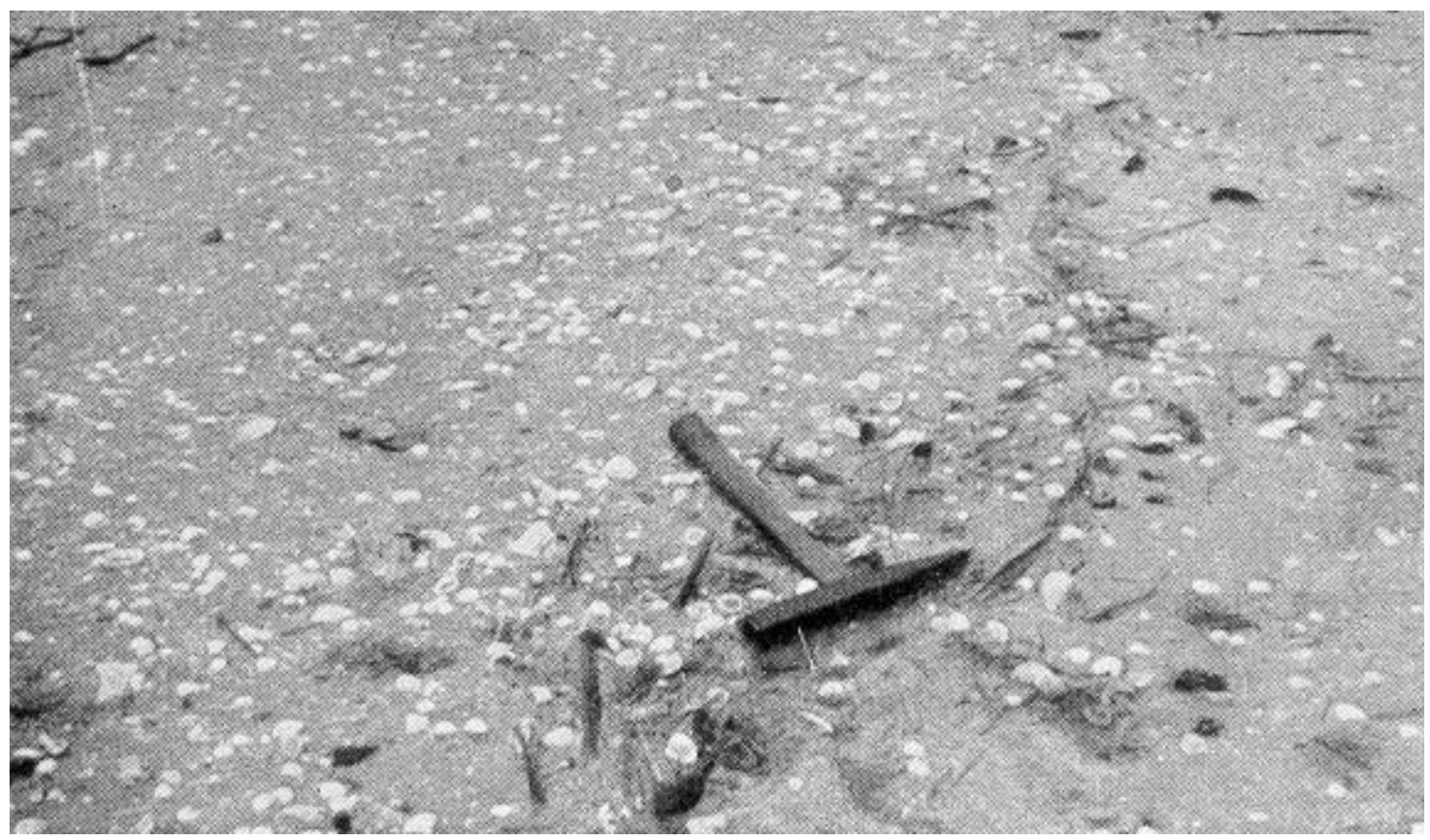

Fig. 37 - Pavimentação com valvas de moluscos na praia de Guaratuba. Cerca de 90\% das valvas acham-se com a concavidade voltada para baixo. Este fato indica um lugar onde predomina a sedimentação.

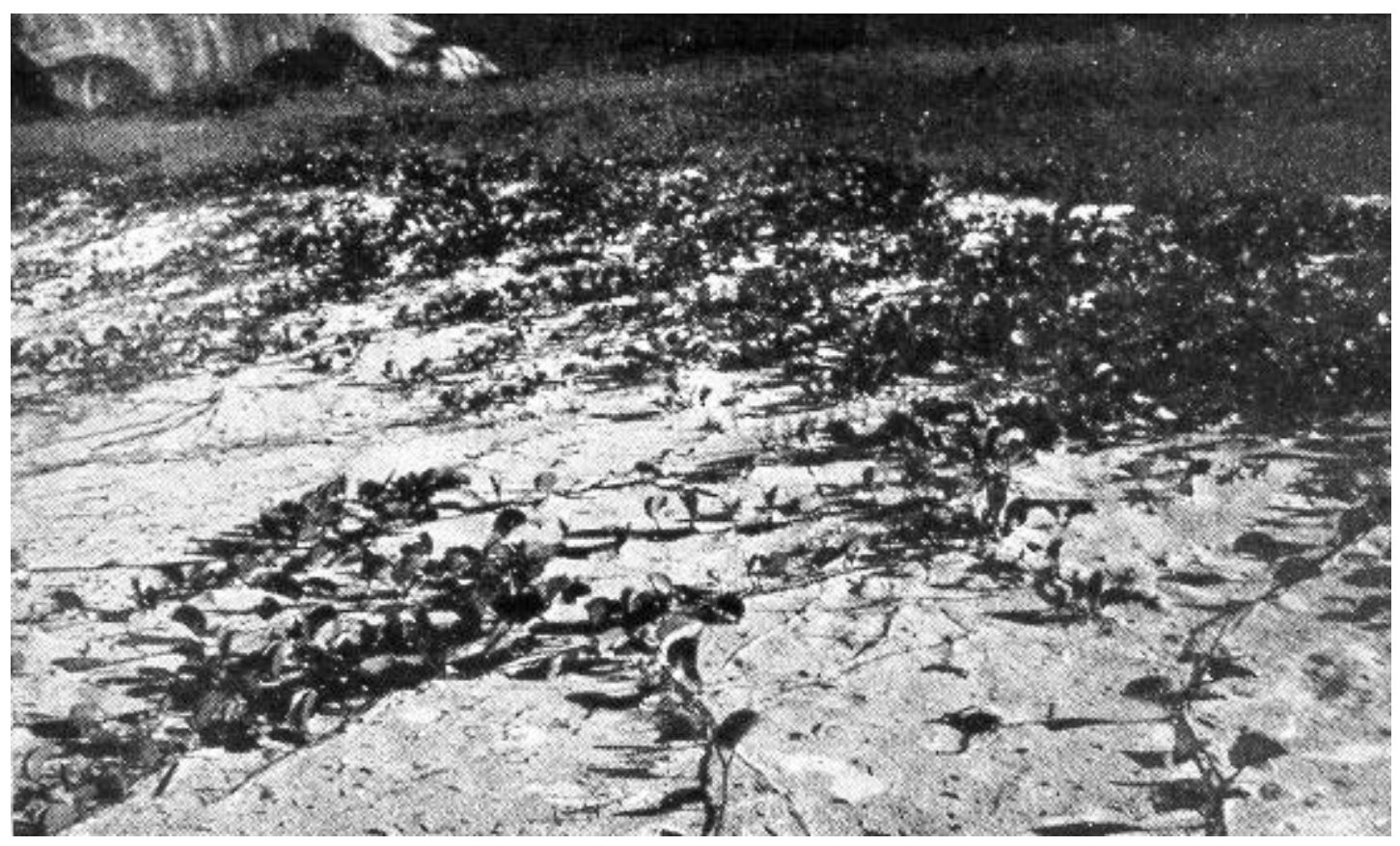

Fig. 38 - Ipomoea pes caprae nas ante-dunas de Caiobá 


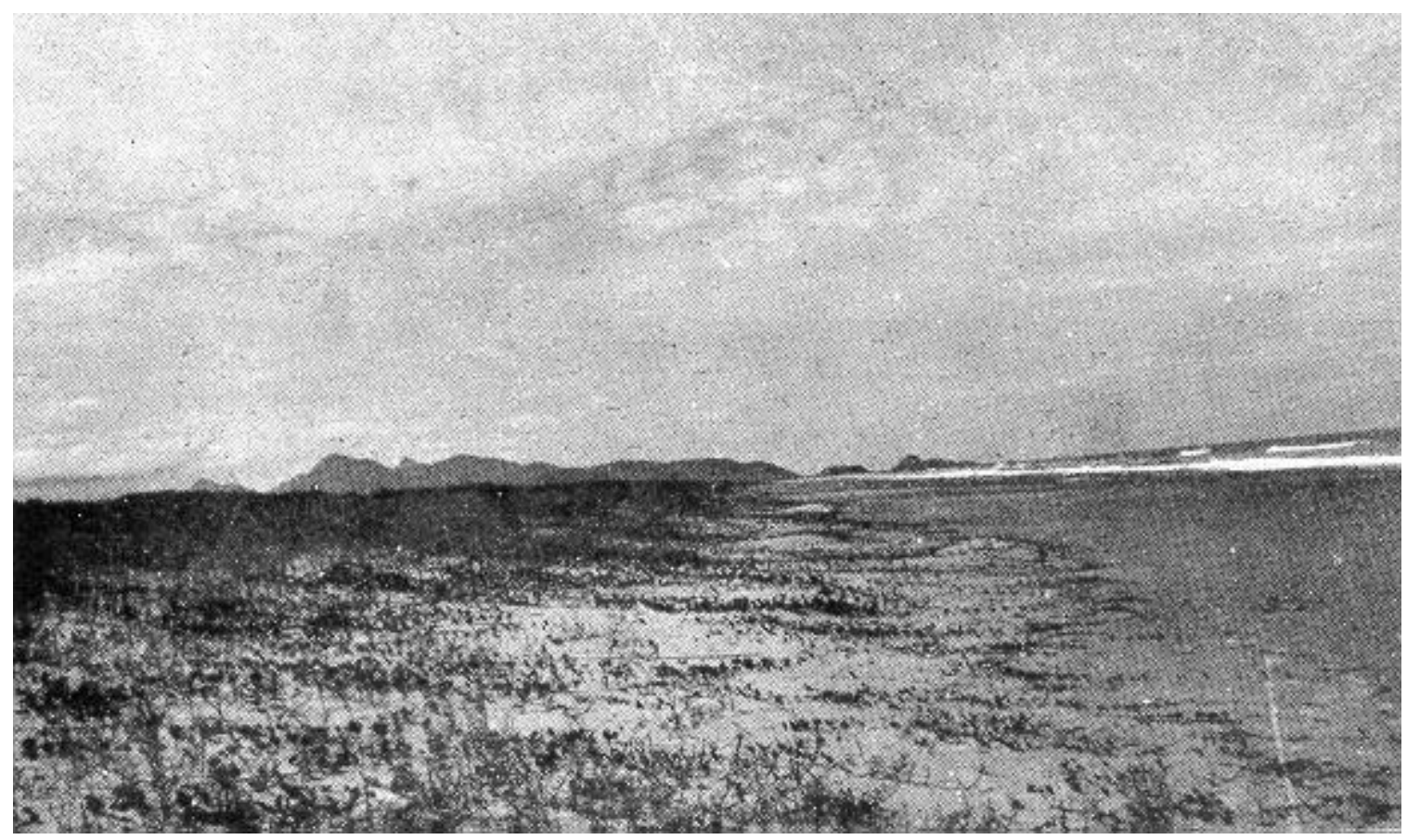

Fig. 39 - Vegetação das ante-dunas na praia do Sul. Vista tomada em direção norte. Ao fundo, o extremo sul da Serra da Prata, à direita ainda no fundo, o morro de Caiobá. Entre este e a serra da Prata, o terraço marinho do morro do Brejetuba, a cerca de $30 \mathrm{~m}$ de altitude.

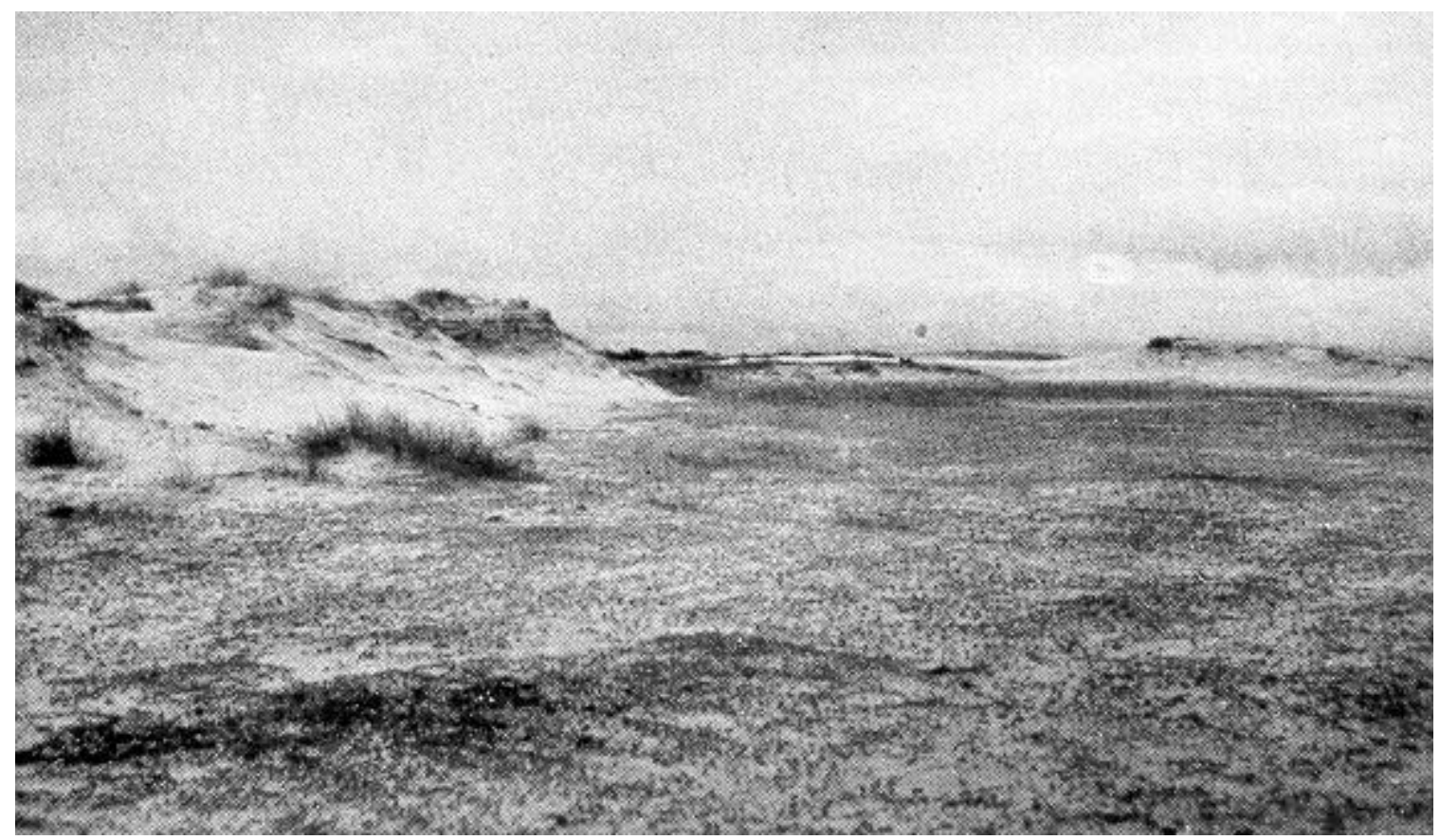

Fig. 40 - Vegetação de fixação das ante-dunas. As pequenas dunas eólicas estão sendo fixadas por gramíneas e ciperáceas. Na parte plana domina a Remirea maritima e a Hydrocotile umbellata. Zona do rio Barranco, Praia de Leste. 


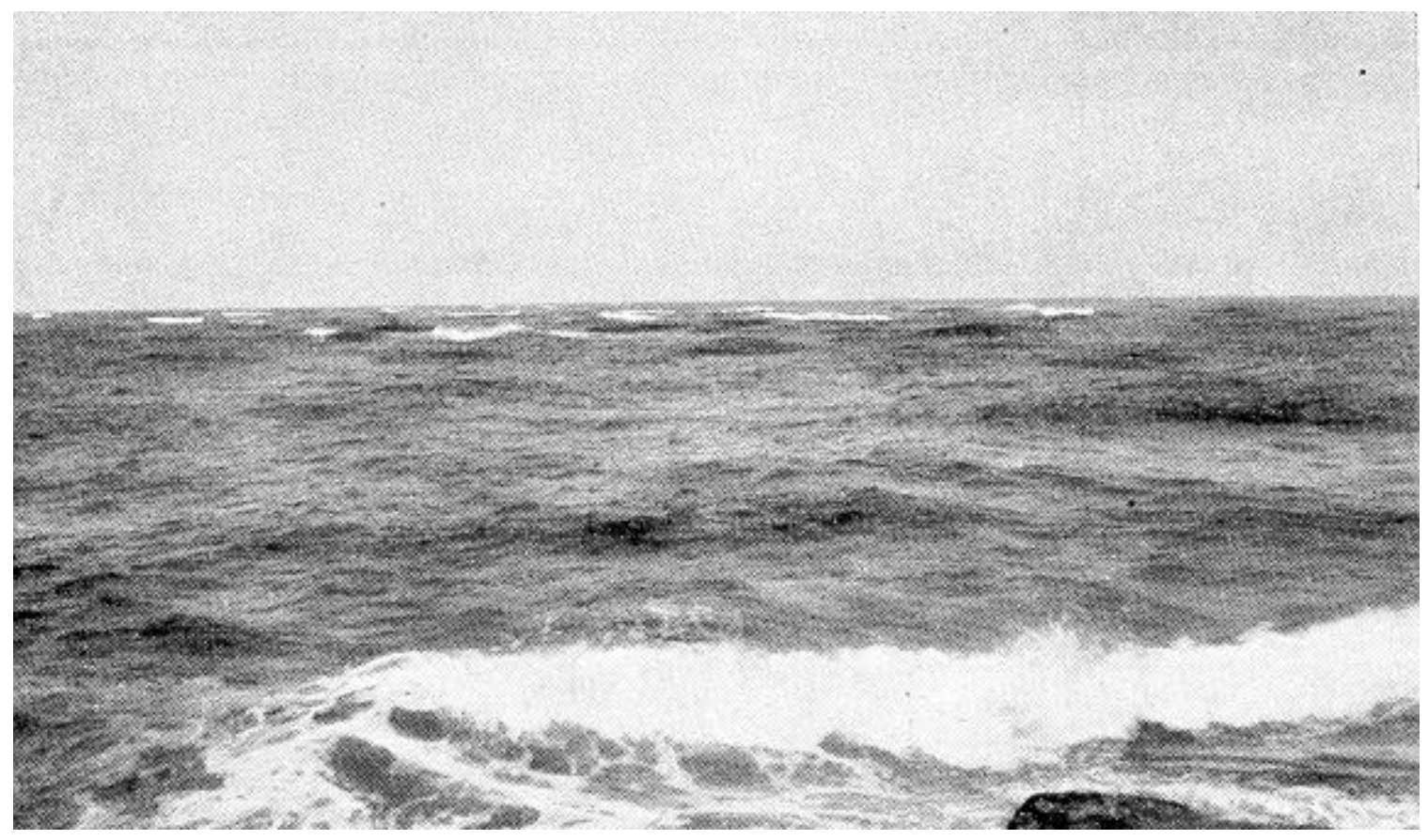

Fig. 41 - Arrebentação das vagas oceânicas sobre bancos de areia submersos. Ilha do Mel.

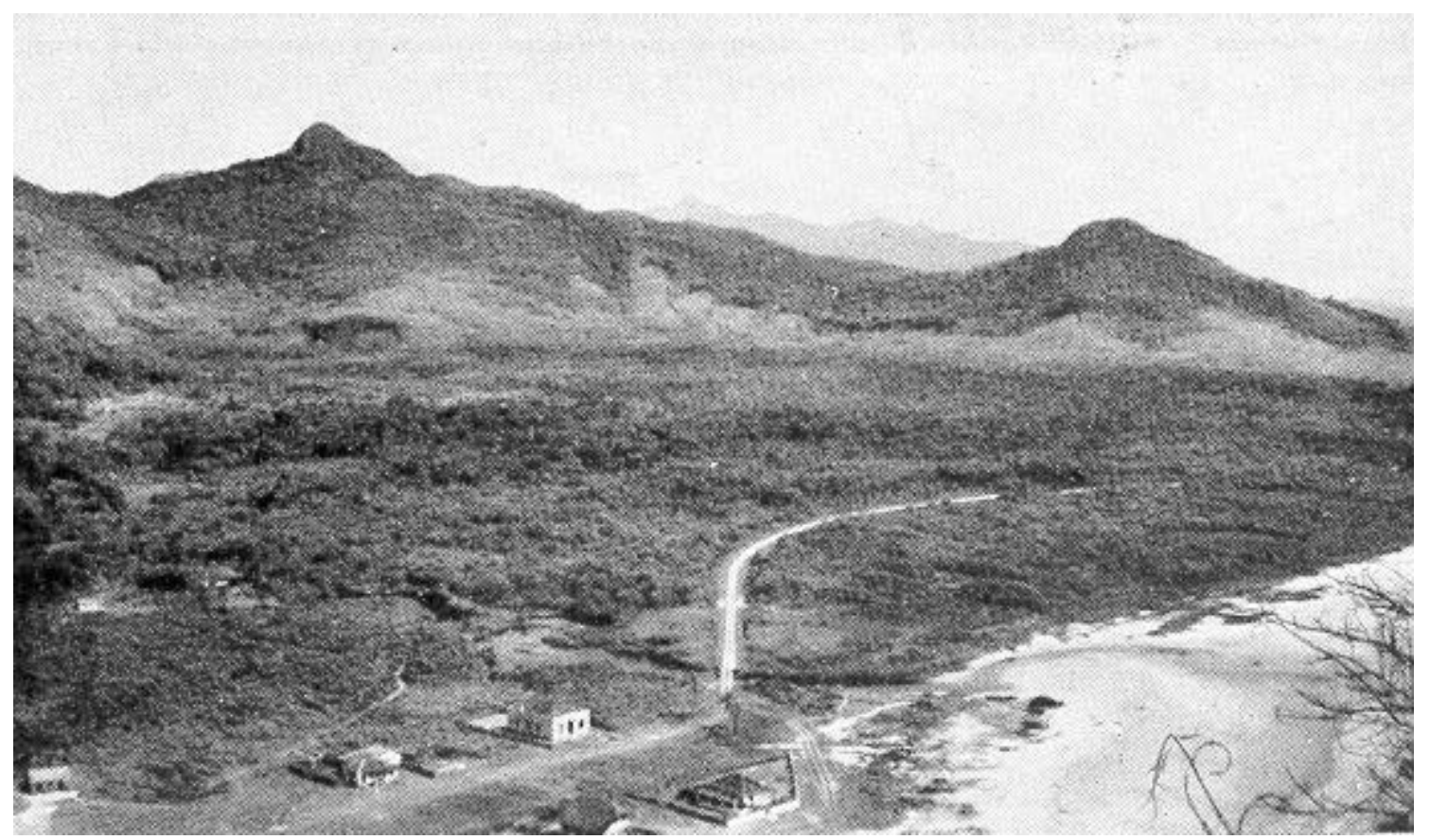

Fig. 42 - Vista parcial da planície litorânea Matinhos-Caiobá, ao sul da praia de Leste. Foto tomada do morro de Caiobá em direção NW. Ao fundo a serra da Prata, à esquerda o morro Tabaraquarinha $(428 \mathrm{~m})$ e à direita o morro Escalvado $(220$ m). Em primeiro plano vista parcial da praia de Caiobá. 


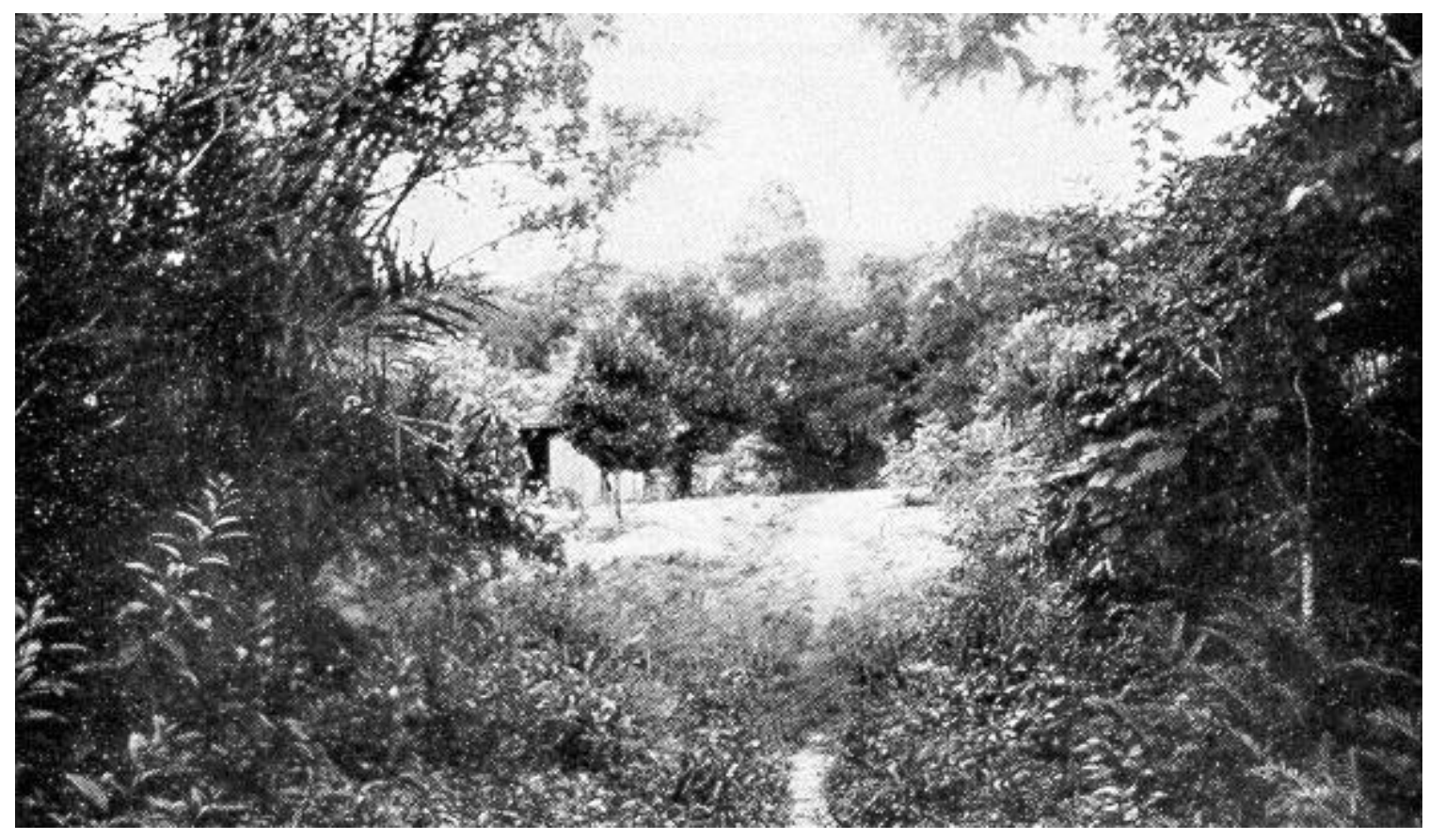

Fig. 43 - Taboleiro arenoso do Sertãozinho, Matinhos, representando um antigo esporão marinho. Ao fundo a serra da Prata. Na frente a parte baixa pantanosa que se estende entre os taboleiros.

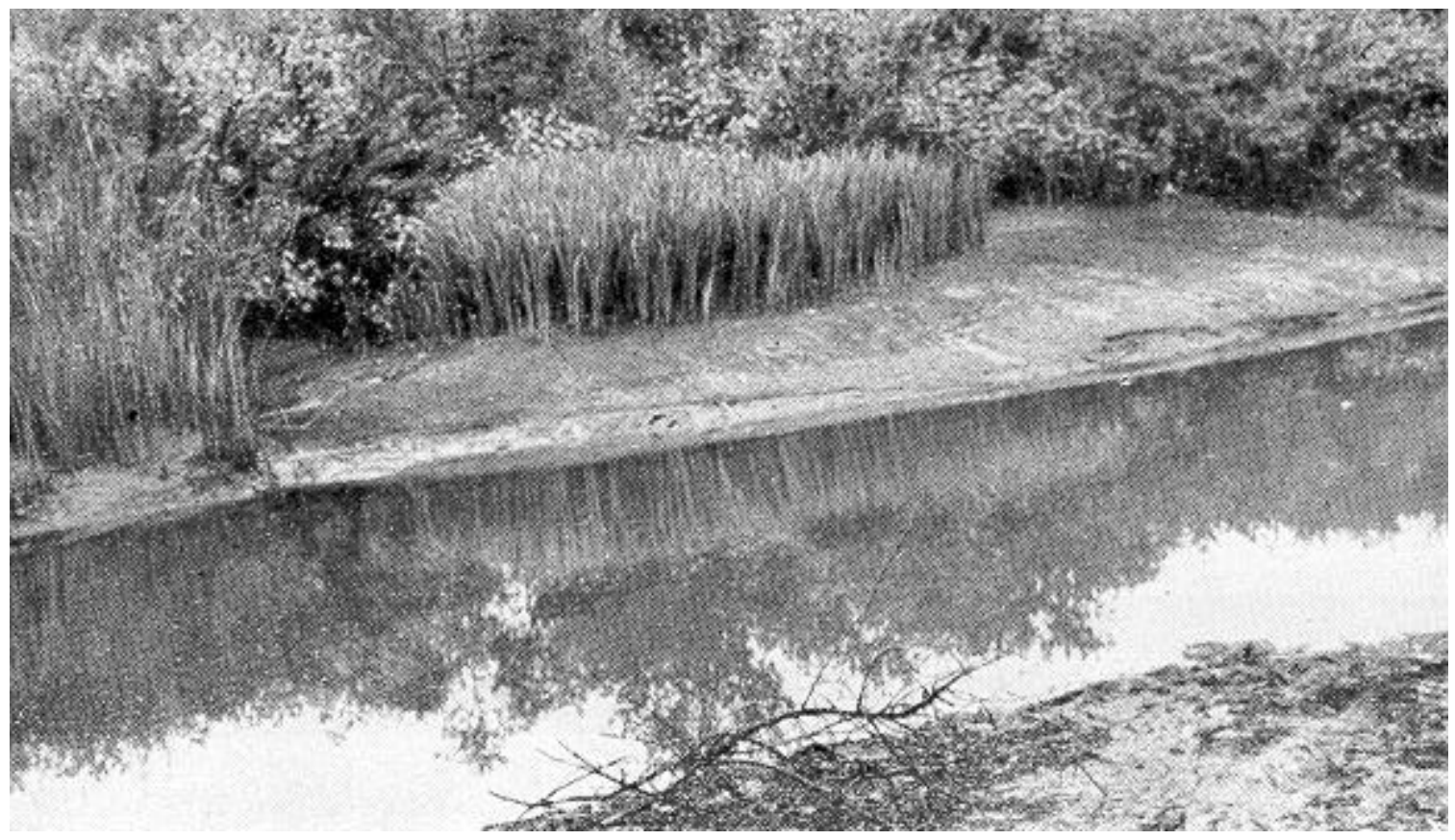

Fig. 44 - Ciperáceas, liliáceas, Hibiscus tiliaceus e alguns exemplares de Laguncularia na parte superior do curso do rio com mangue. Foto tomada durante a baixa-mar. Rio Monte Alegre (afluente da margem esquerda do Nhundiaquara), Antonina. 


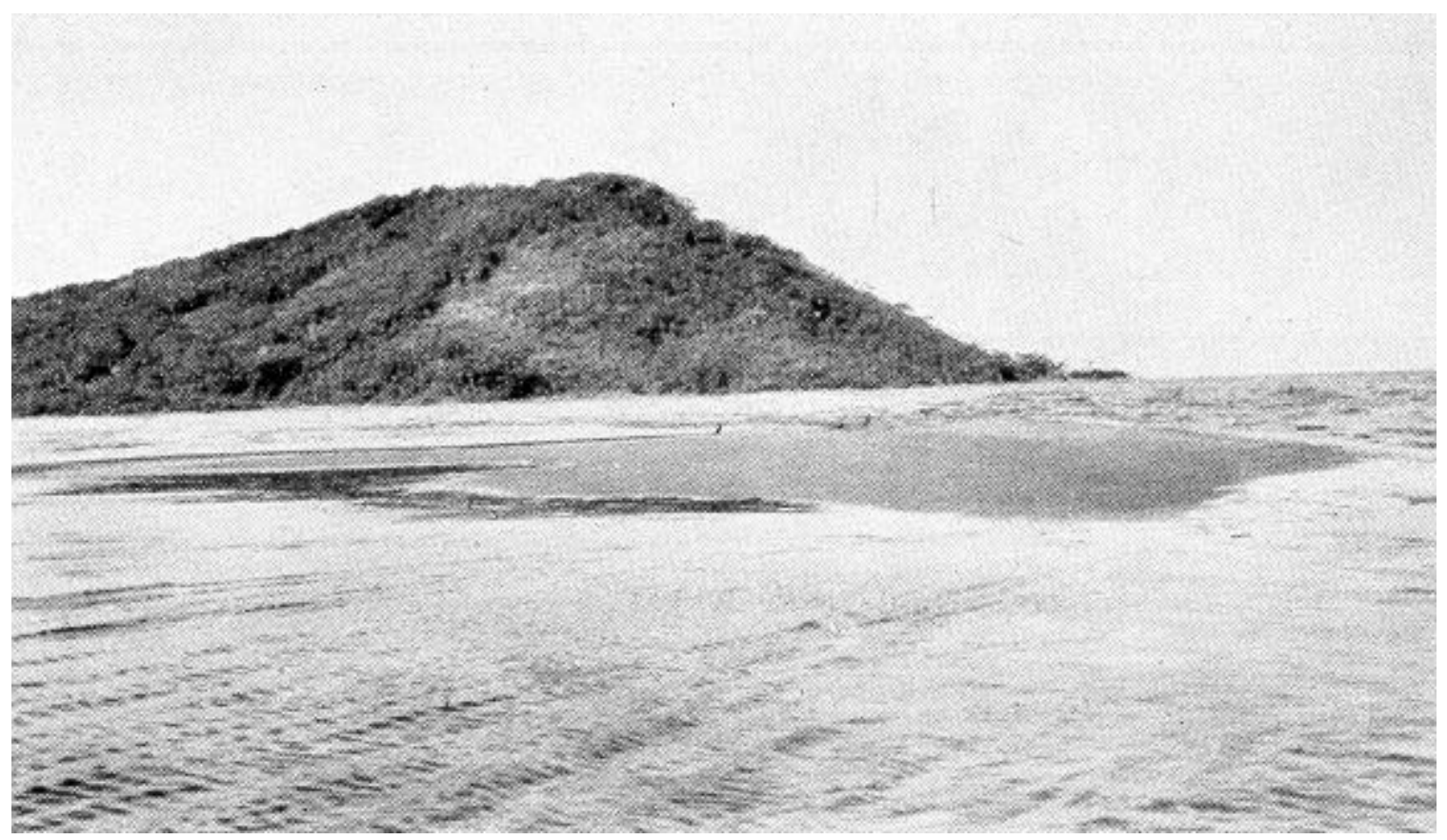

Fig. 45 - Banco areno-argiloso, emerso na baixa-mar. Ponta do Ribeiro, baia de Guaratuba. Ao fundo, morro e ponta da Passagem.

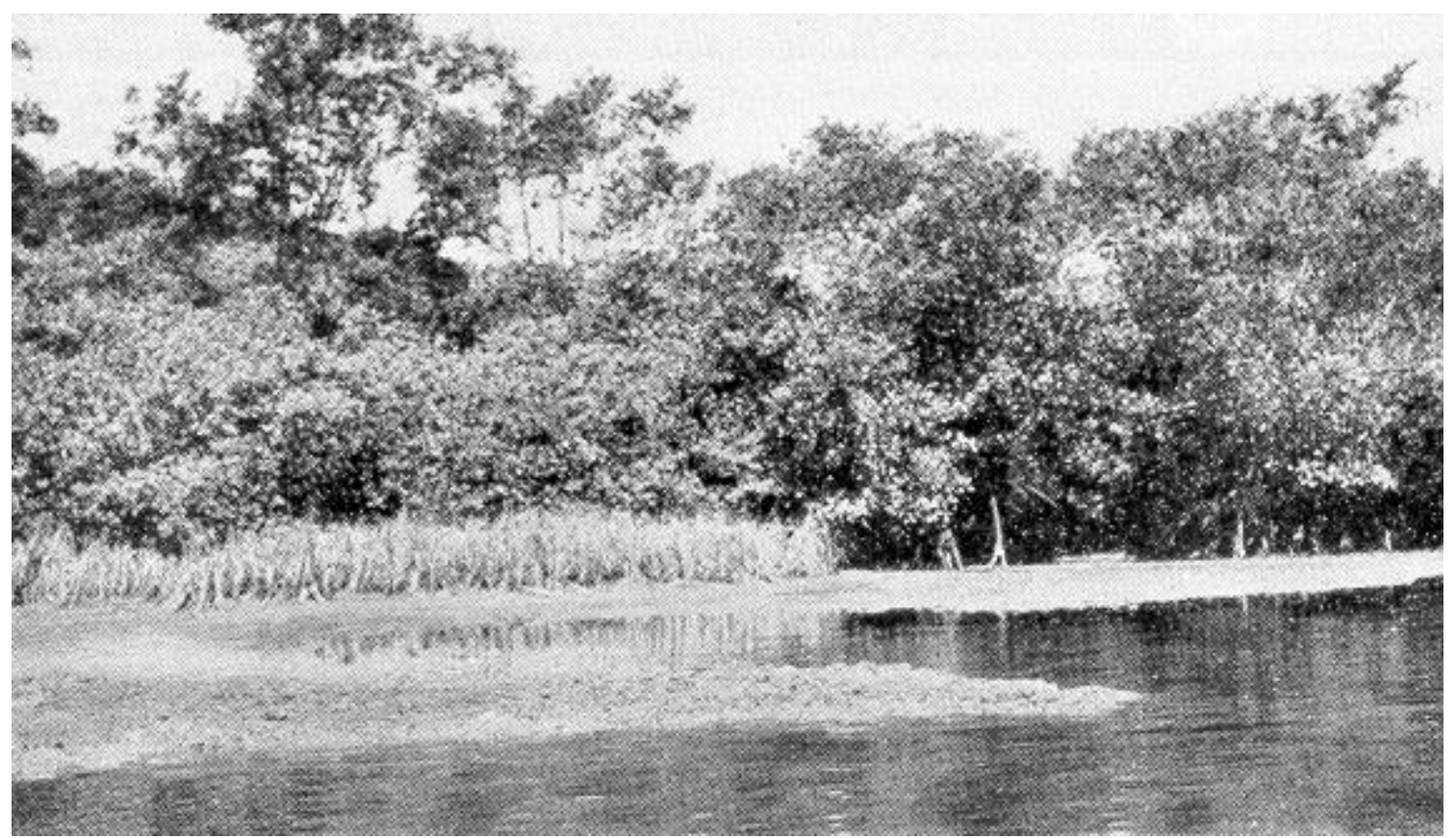

Fig. 46 - Manguezal no rio Tabaraquara, baia de Guaratuba. Na frente bancos de lodo seguidos de "praturá" - S. brasiliensis e do mangue propriamente dito. Entre as espécies do mangue destacam-se pelo porte decrescente a Avicennia tomentosa, Rhizofora Mangle, com suas raízes de sustentação e a Laguncularia racemosa, dominante nos manguezais paranaenses. 


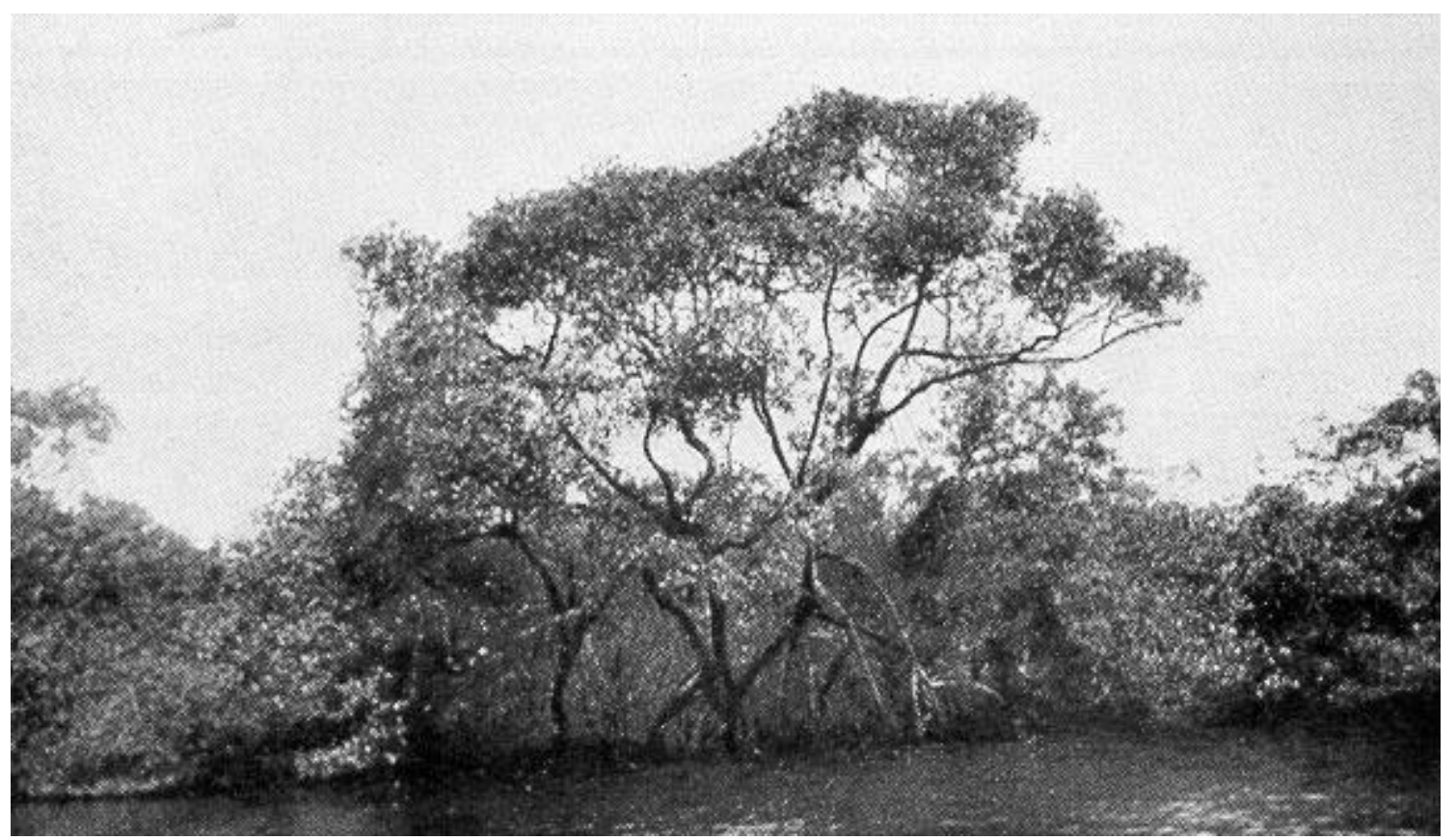

Fig. 47 - Rhizofora Mangle, com suas raízes de sustentação, sobresaindo-se da Laguncularia racemosa, nos manguezais do rio Tabaraquara, baia de Guaratuba. À esquerda e à direita notam-se exemplares de Avicennia tomentosa.

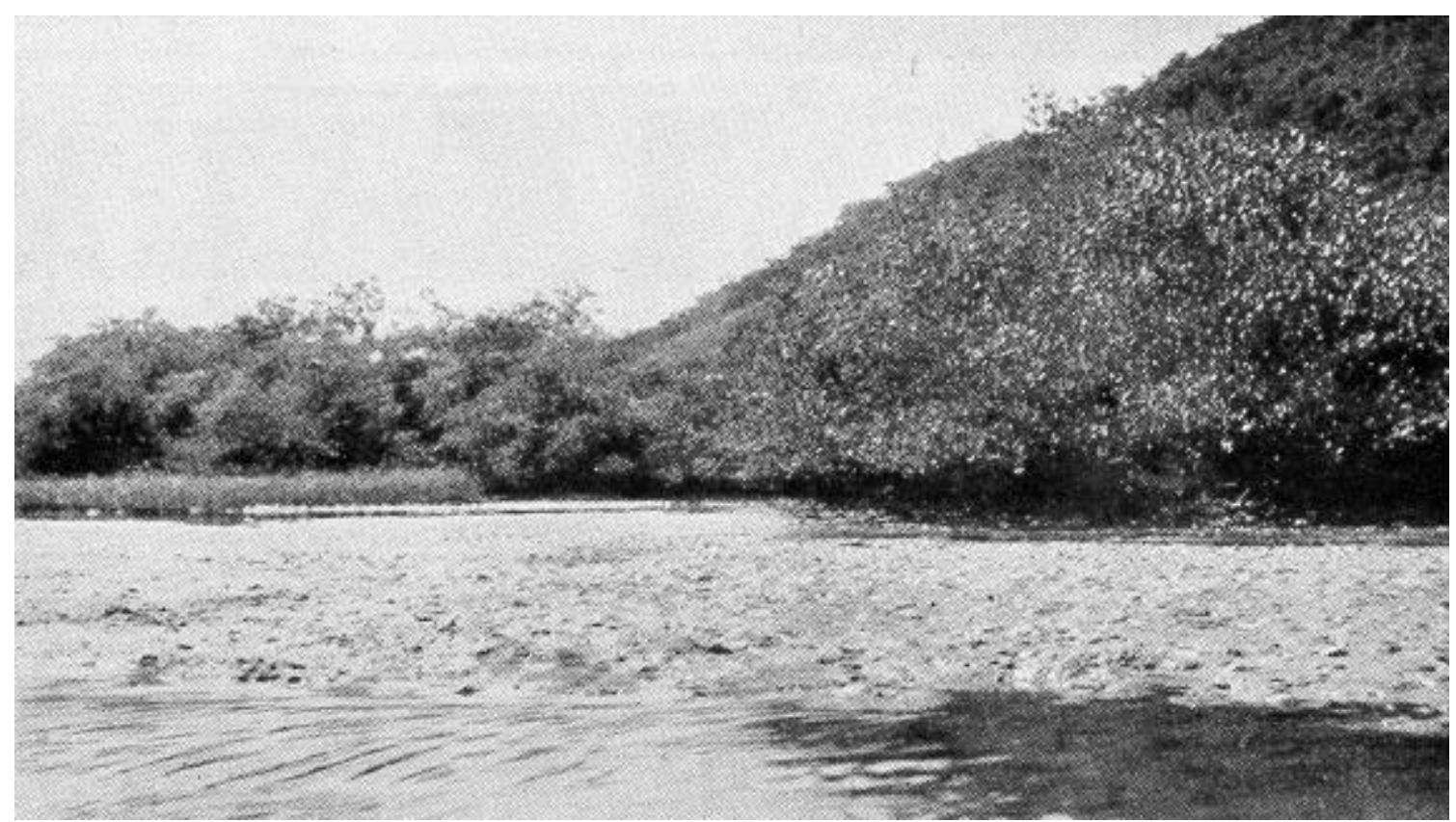

Fig. 48 - Na direita da foto, vê-se a Laguncularia racemosa, caracterizada pelo menor porte entre os 3 constituintes principais do manguezal. Na esquerda, salientase no bosque de mangue a Avicennia, na frente do mesmo viceja o "praturá"S. brasiliensis. Na frente da foto, umbanco de lodo emergente na baixa-mar. Rio Tabaraquara, baia de Guaratuba. 


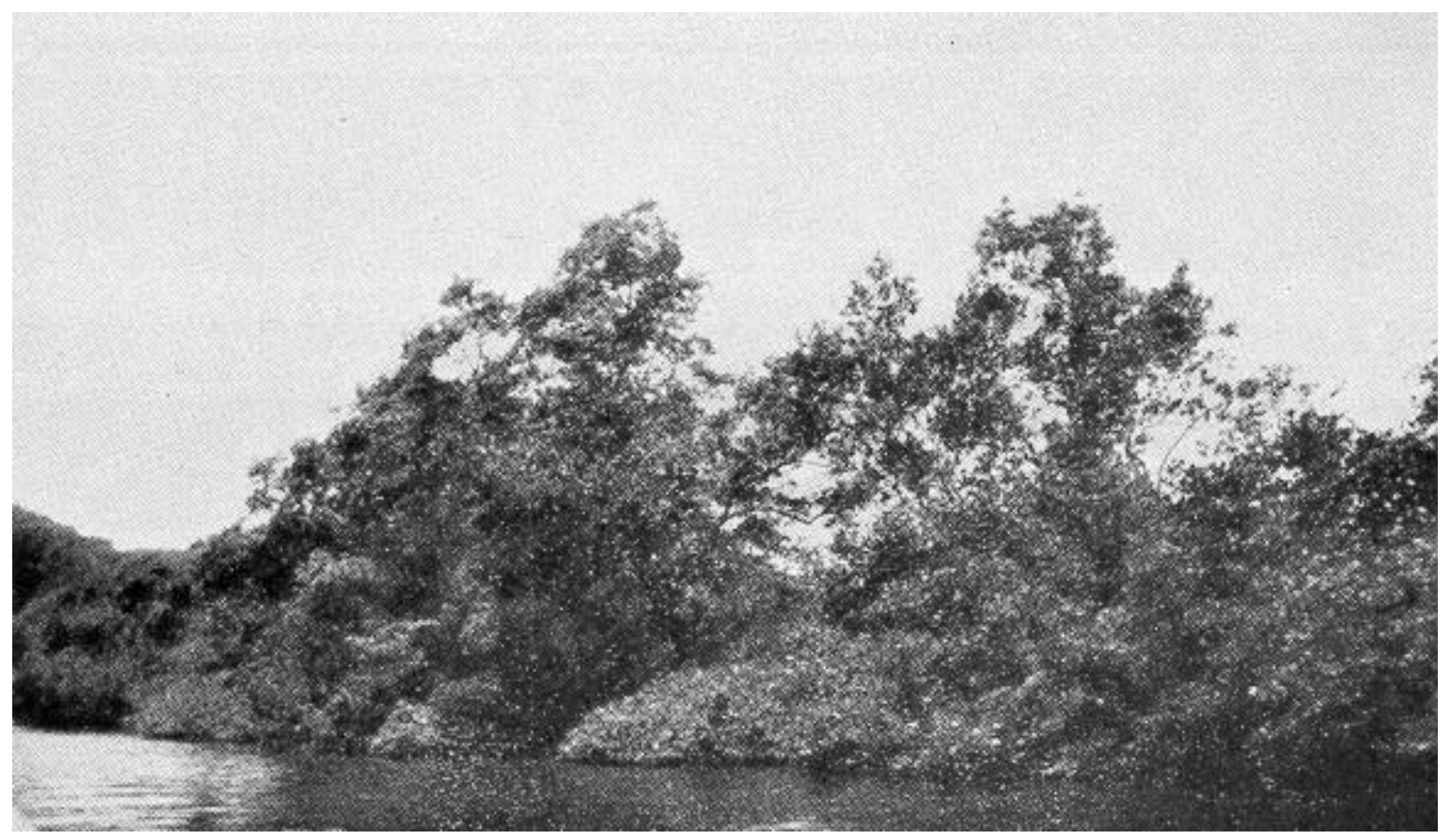

Fig. 49 - Avicennia tomentosa, caracterizada pelo maior porte entre os constituintes do manguezal. Os grupos vegetais de menor altura, são compostos principalmente pela Laguncularia racemosa. Rio Tabaraquara, baia de Guaratuba.

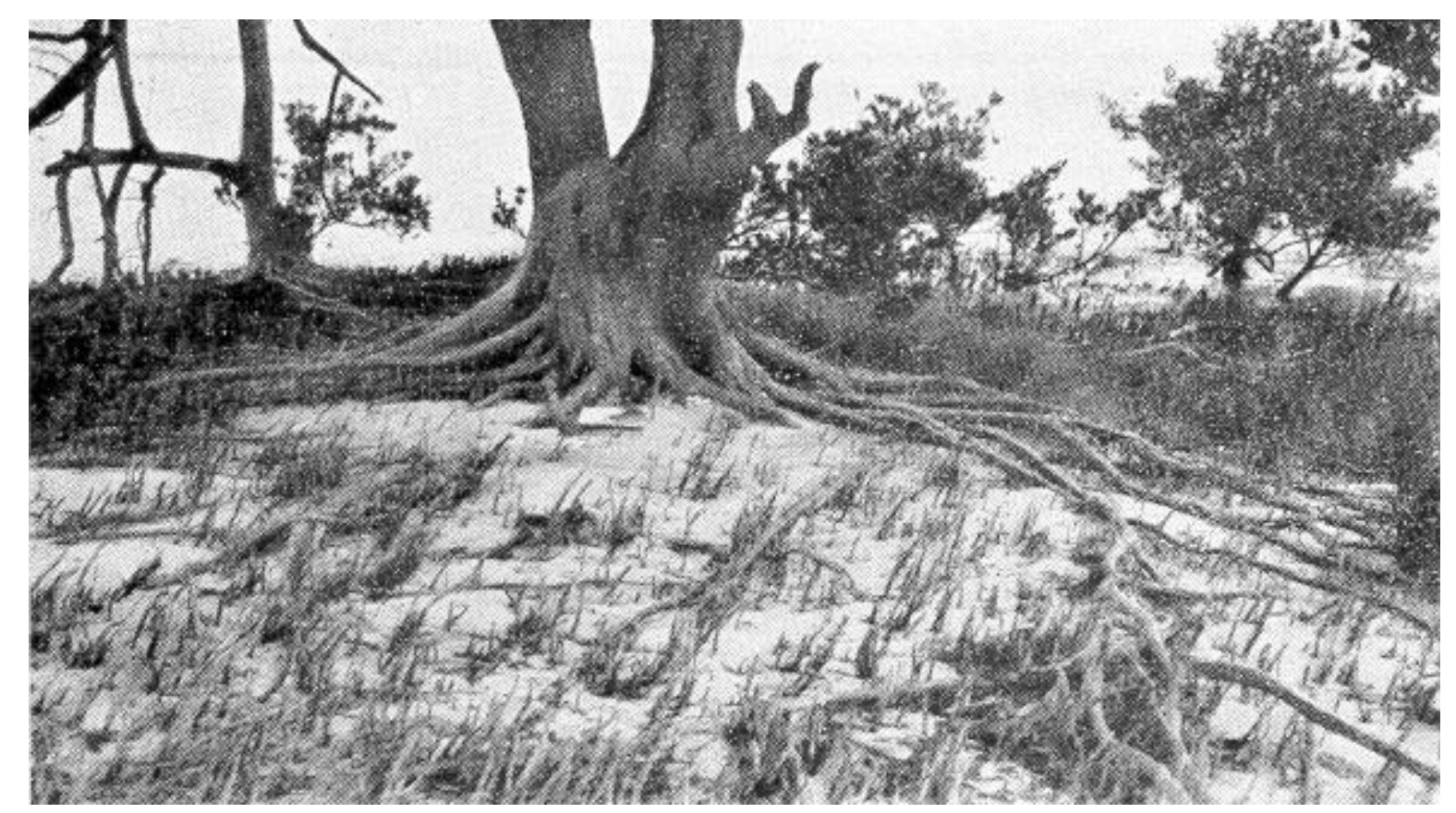

Fig. 50 - Tronco, raízes e pneumatóforos da Avicennia tomentosa. No fundoalguns pequenos exemplares de Laguncularia racemosa e "praturá" - S. brasiliensis. Mar de Dentro, baia de Paranaguá. 


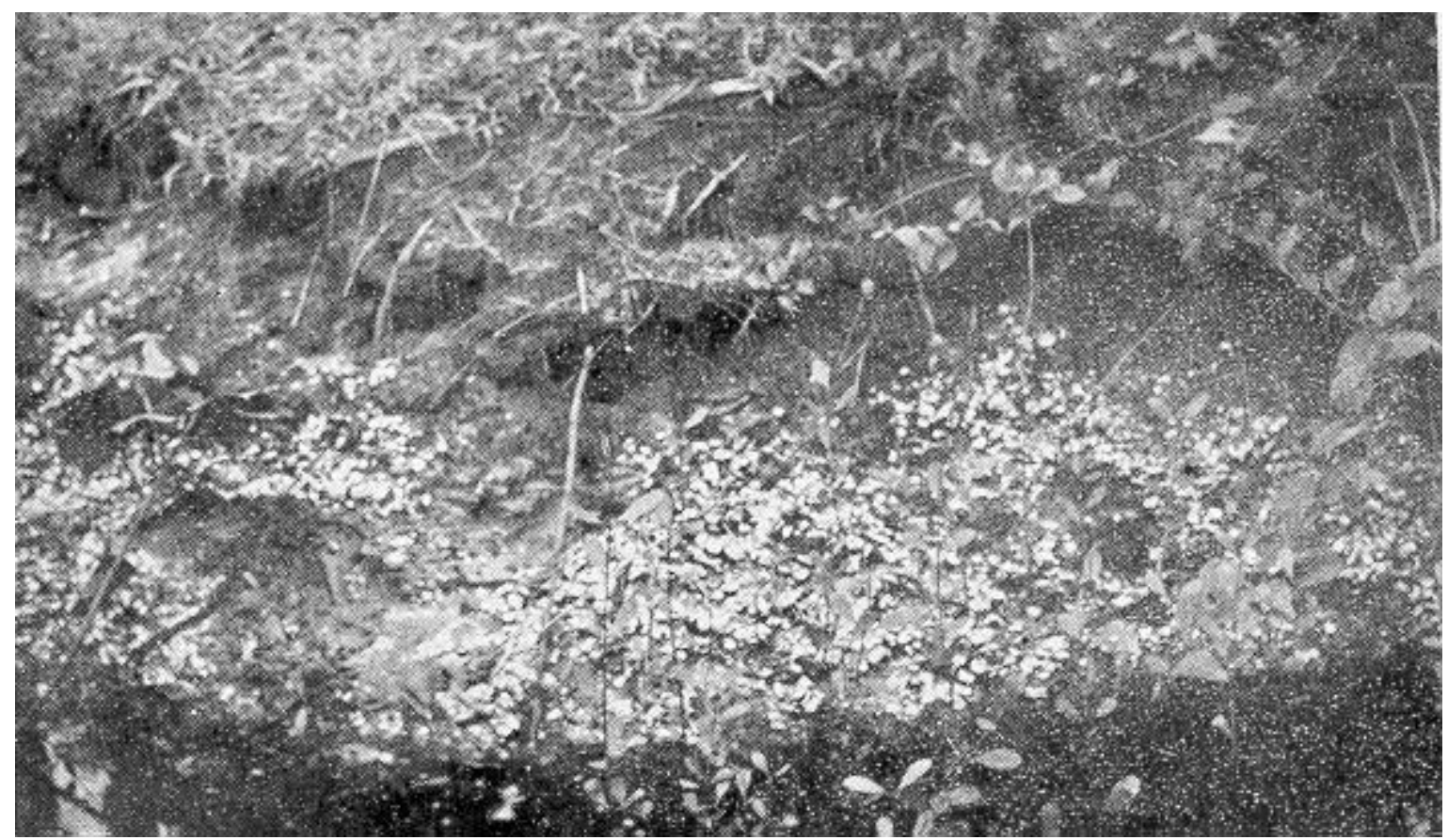

Fig. 51 - Banco areno-argiloso, situado a cerca de 1,3 m sobre o nível do rio. Contém intercalada uma camada de $0,3 \mathrm{~m}$ a $0,4 \mathrm{~m}$ de pelecípodos e gasterópodos. Esta camada não é mais atingida pela preamar. Constitui um banco fossilífero, cujos sub-fósseis são espécies ainda hoje viventes. Rio Boguaçú, baia de Guaratuba.

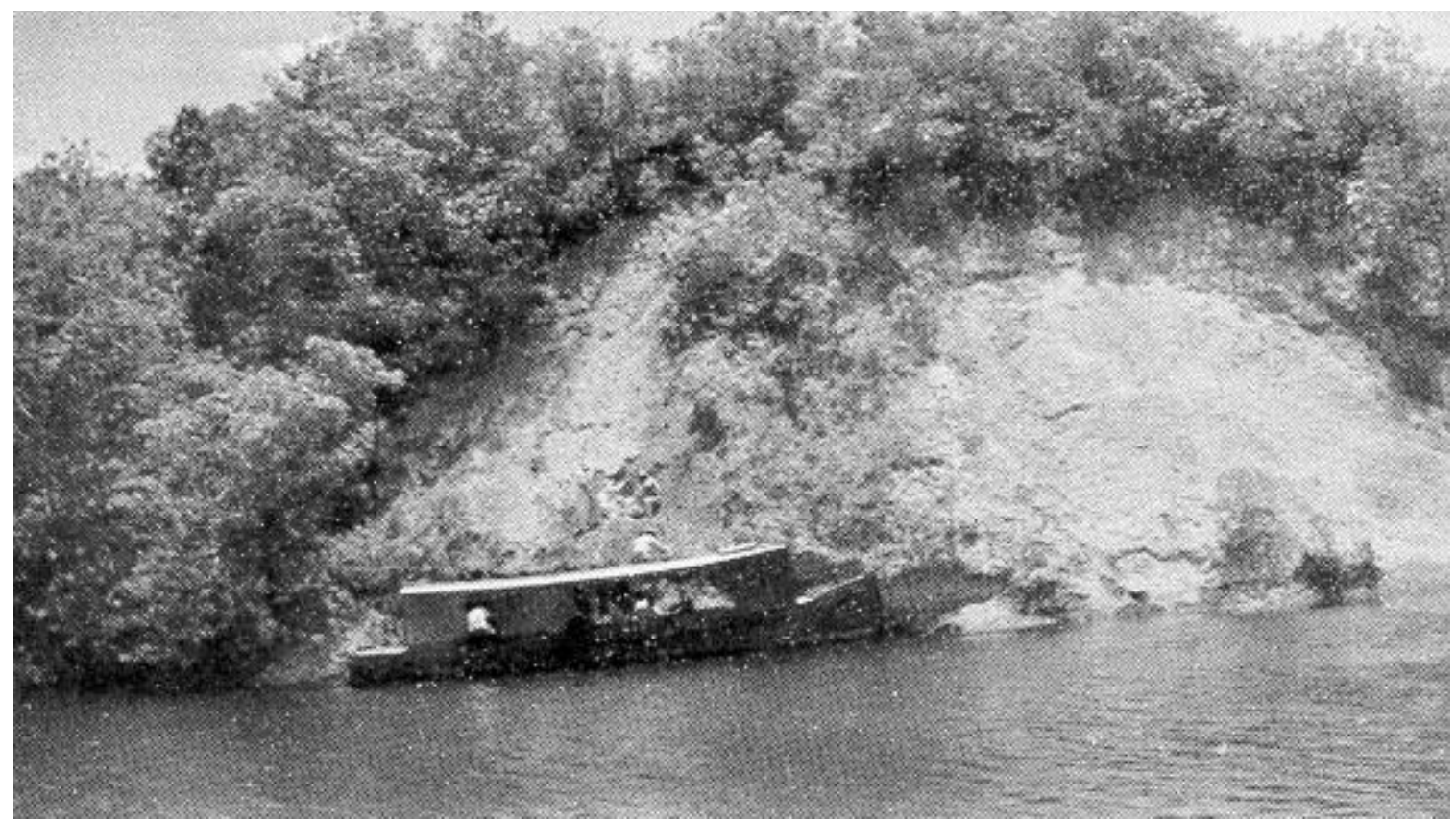

Fig. 52 - Sambaqui da margem esquerda do rio Boguaçú. Sua base situa-se a cerca de $1,3 \mathrm{~m}$ sobre o rio (aproximadamente igual ao nível do mar). O sambaqui tem aproximadamente $15 \mathrm{~m}$ de altura. 


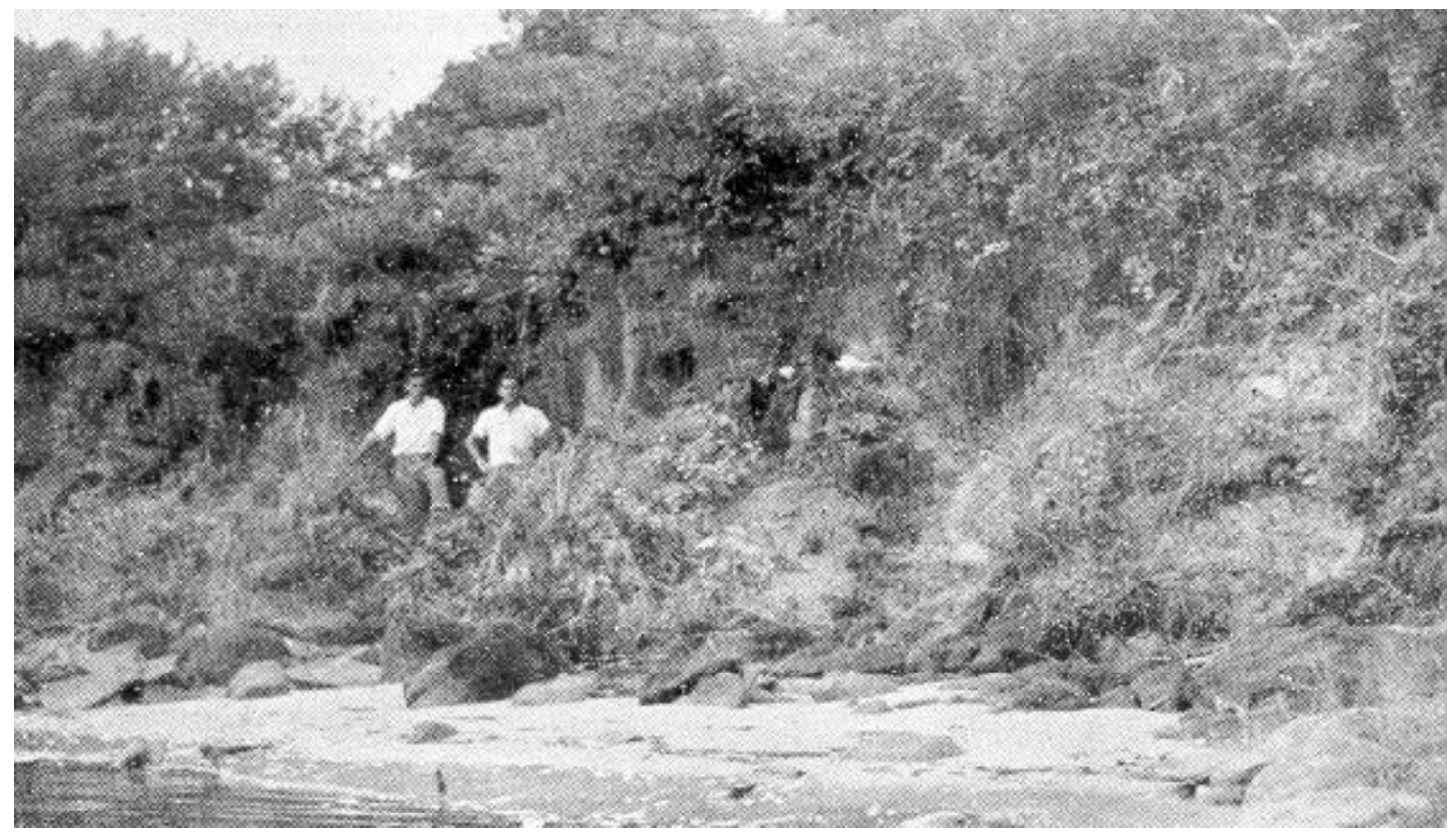

Fig. 53 - Mangrovito - banco de sedimentos arenosos escuros, com cerca de $2 \mathrm{~m}$ de possança, representando antigos manguezais solevados sobre o nível do mar. Constituem taboleiros arenosos semelhantes aos de restinga. $\mathrm{Na}$ frente vê-se blocos formados por um "arenito friável", que não se desfaz em contato com a água. Piçarras, baia de Guaratuba.

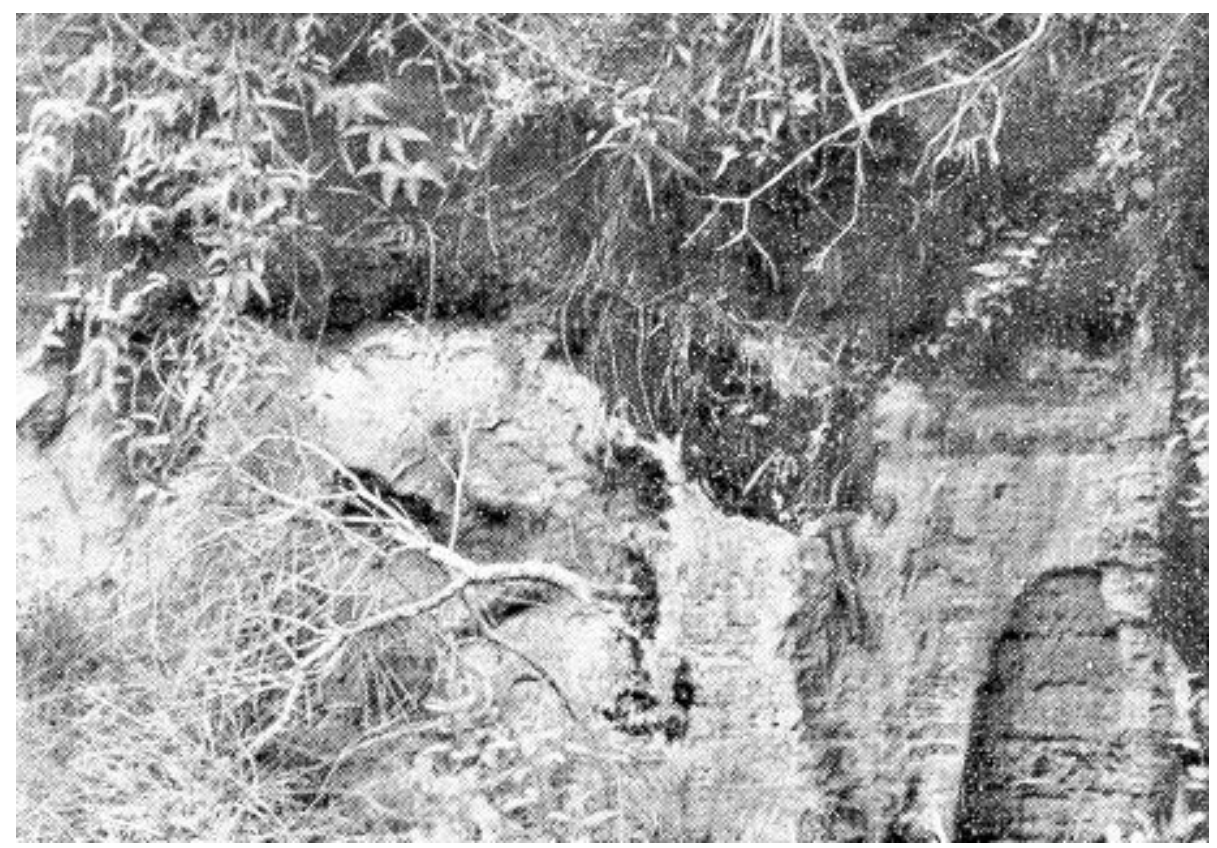

Fig. 54 - Estratificação paralela observada no mangrovito. Rio Emboguaçú, estrada de rodagem Alexandra - Paranaguá. 


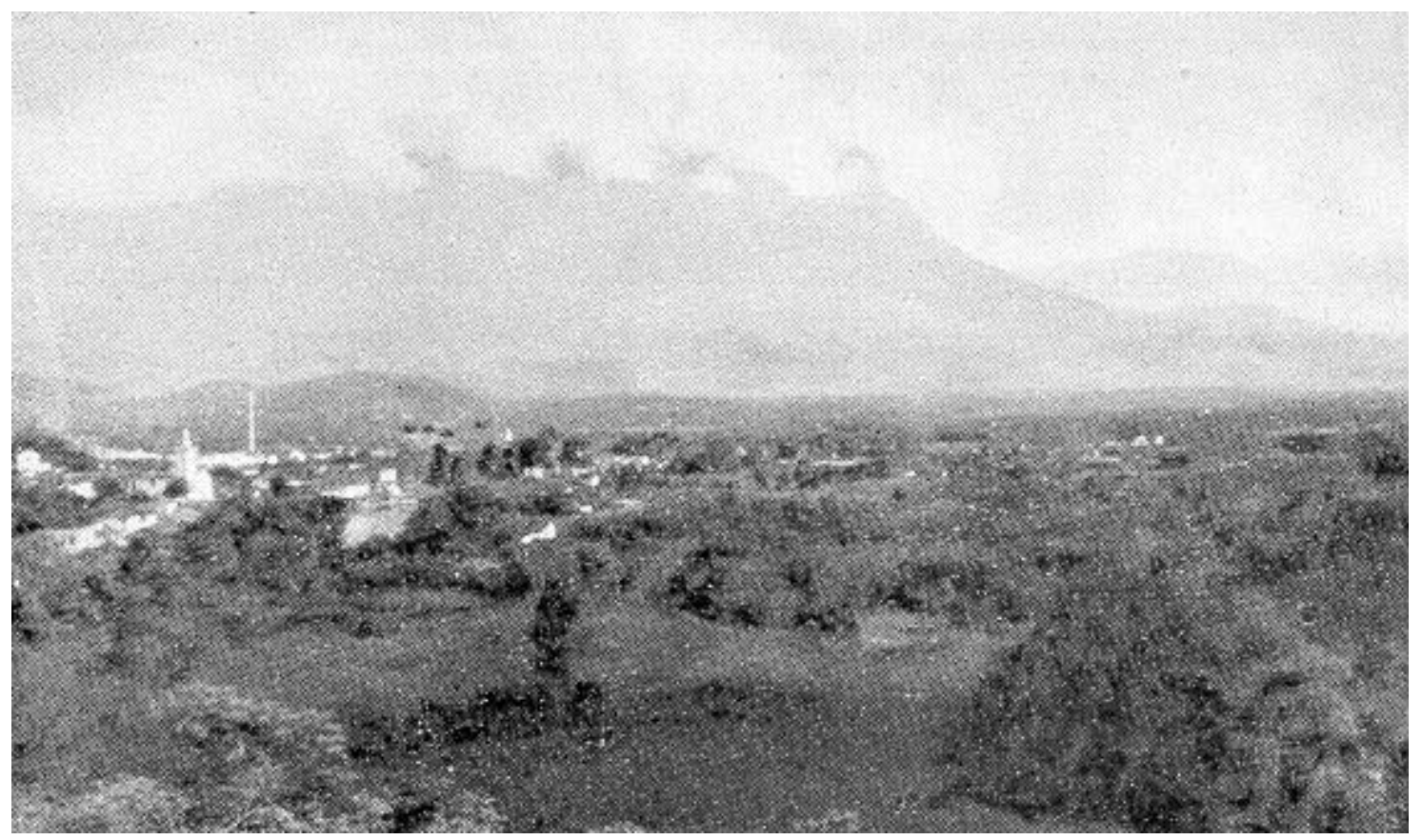

Fig. 55 - planície aluvial de Morretes, constituída por terrenos de aluvião terrestre. Ao fundo o Pico do Marumbi com $1547 \mathrm{~m}$ de altitude. Na frente, a cidade de Morretes às margens do Nhundiaquara.

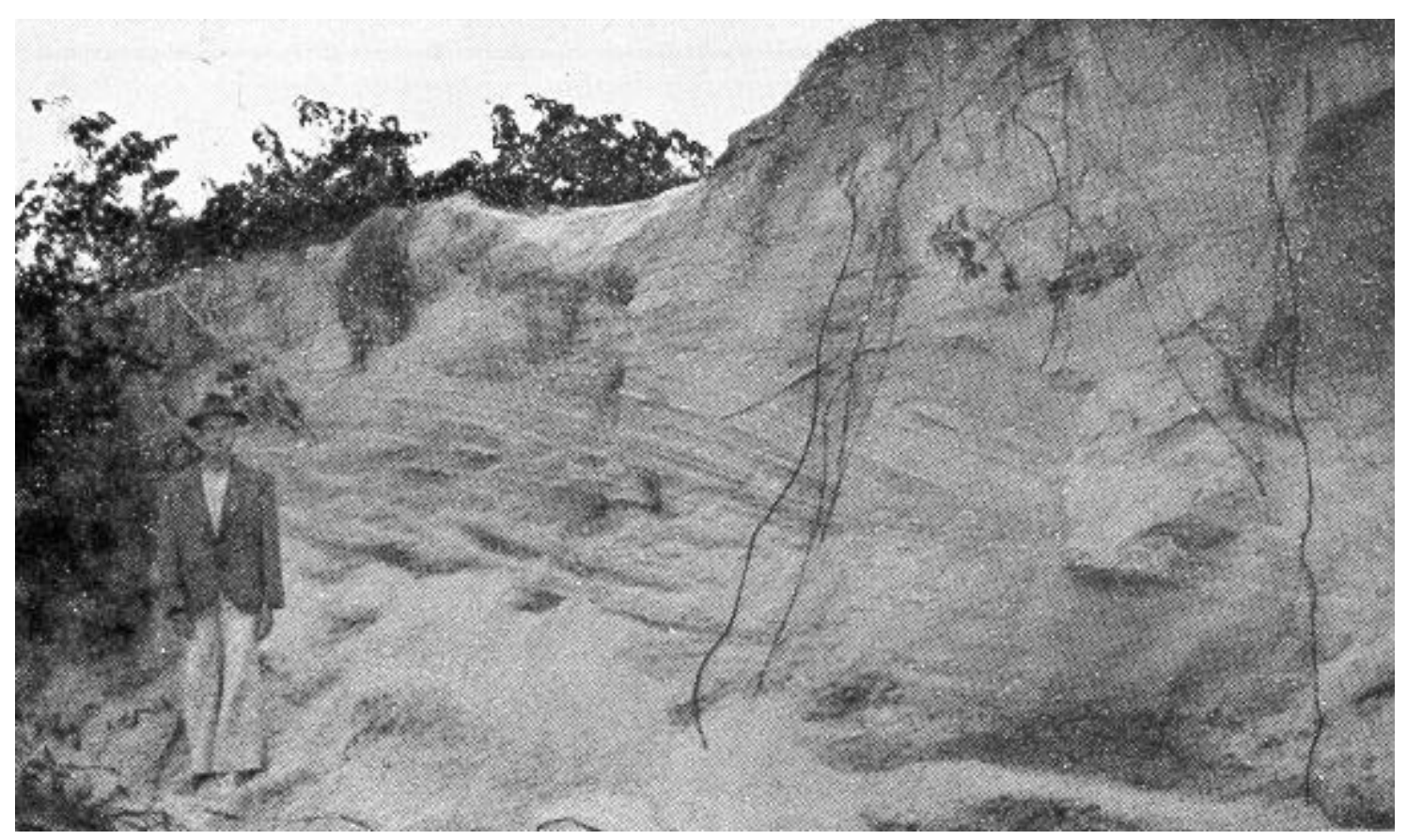

Fig. 56 - Estrutura eólica de uma pequena duna, aberta em cliff por um avanço do mar na região do Pontal do Sul, praia de Leste. 


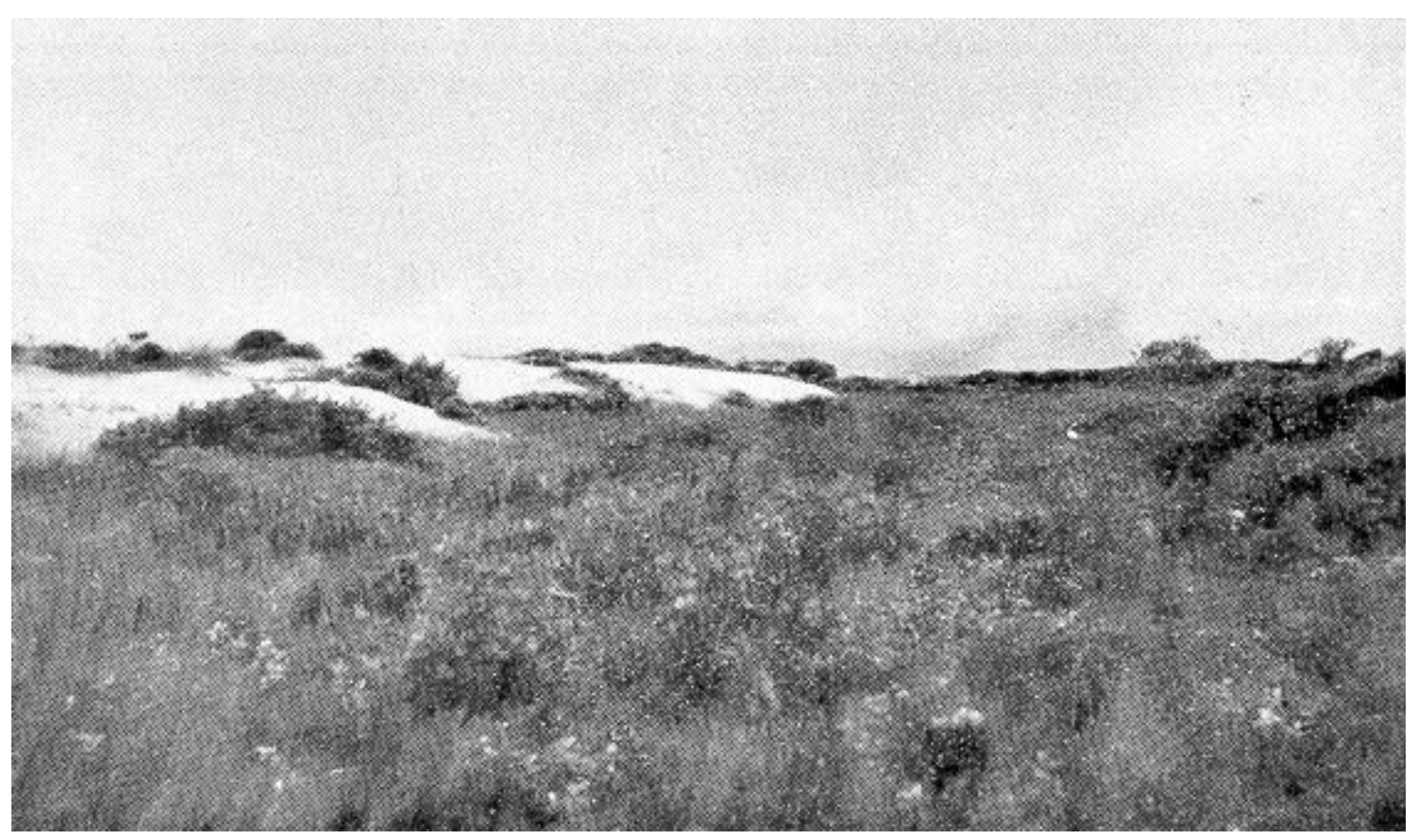

Fig. 57 - Cunhas de areias eólicas avançando sobre a restinga. Zona do rio Barranco, praia de Leste

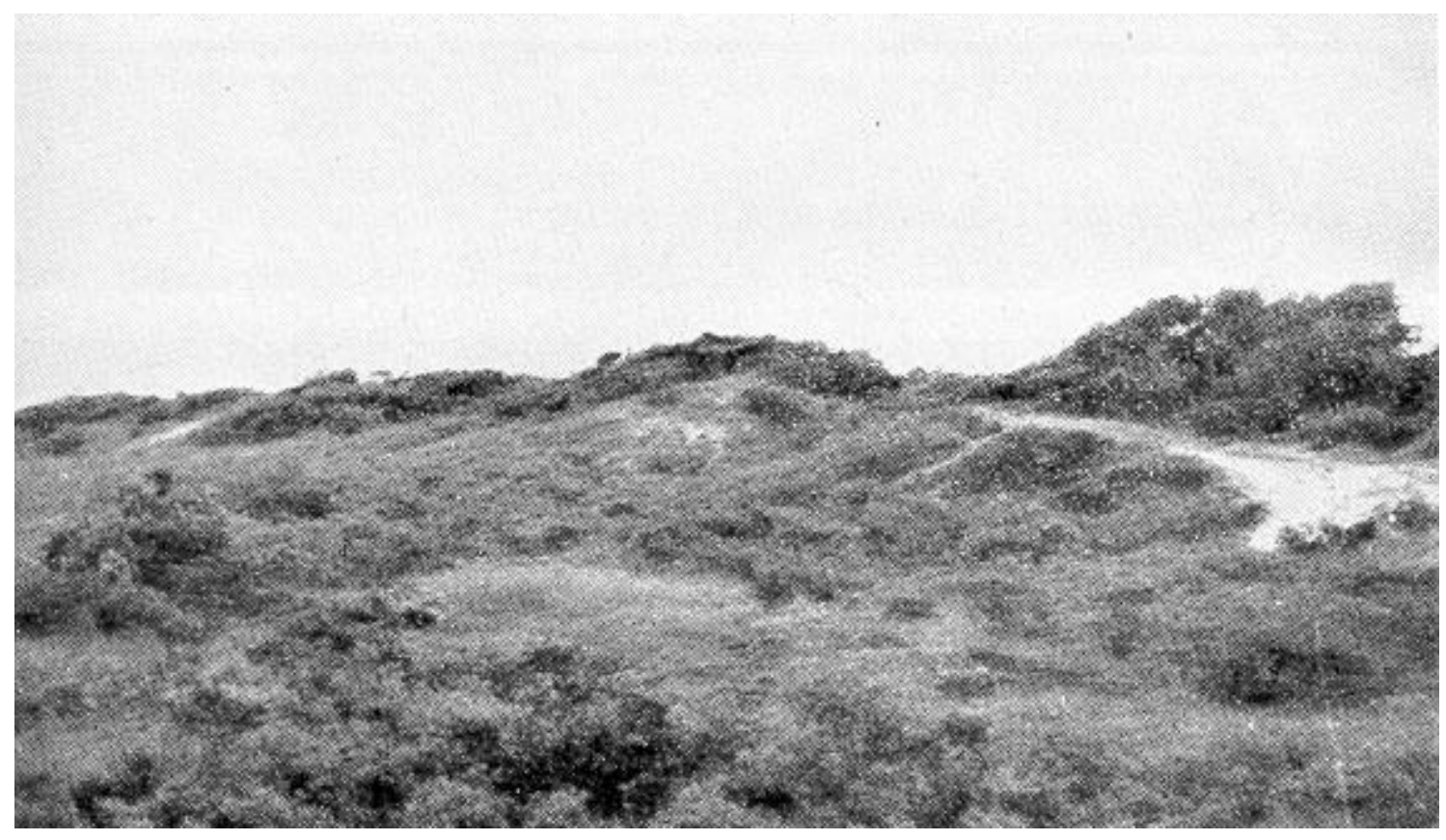

Fig. 58 - Pequenas dunas eólicas fixas pela vegetação de restinga com 5 a $7 \mathrm{~m}$ de altura. Alinham-se em forma de cordões paralelos à linha de costa. Zona do rio Barranco, praia de Leste. 